\title{
THE INFLUENCE OF CHILLING AND HEAT ACCUMULATION ON BLOOM TIMING, BLOOM LENGTH AND CROP YIELD \\ IN ALMONDS (Prunus dulcis (Mill.))
}

\author{
A Thesis \\ presented to \\ the Faculty of California Polytechnic State University, \\ San Luis Obispo \\ In Partial Fulfillment \\ of the Requirement for the Degree of \\ Master of Science in Agriculture, Specialization in Crop Science \\ by \\ Melanie Marie Covert \\ December, 2011
}


(C)2011

Melanie Marie Covert

ALL RIGHTS RESERVED

ii 
TITLE:

AUTHOR:

DATE SUBMITTED:

COMMITTEE CHAIR:

COMMITTEE MEMBER:

COMMITTEE MEMBER:
The Influence of Chilling and Heat Accumulation on Bloom Timing, Bloom Length and Crop Yield in Almonds (Prunus dulcis (Mill.))

Melanie Marie Covert

December, 2011

Dr. Mary E. Pedersen, Associate Dean of the College of Agricultural, Food and Environmental Sciences

Dr. Lauren Garner, Associate Professor, Horticulture and Crop Sciences

Dr. Jeffery Wong, Associate Professor, Horticulture and Crop Sciences 


\begin{abstract}
The Influence of Chilling and Heat Accumulation on Bloom Timing, Bloom Length and

Crop Yield in Almonds (Prunus dulcis (Mill.))

Melanie Marie Covert

Almonds are one of the first commercial nut trees to bloom in early spring and thus are susceptible to temperature patterns prior to and during bloom which affect bloom timing, bloom length, pollination and nut set. Data used in this project include yearly dates of $90 \%$ bloom from 1996-2006, bloom length in days and final crop yields in pounds per tree for Nonpareil and Mission varieties. Data were collected from the University of California Cooperative Extension reports on the 1993-2006 Regional Almond Variety Trials in Butte, San Joaquin and Kern Counties. Temperature pattern models in the form of Chill Hours (Chill Hour Model), Chill Units (Chill Unit Model), Chill Portions (Chill Portion Model) and Growing Degree Hours $\left(\mathrm{GDH}^{\circ}\right)$ (Heat Model) prior to bloom were used to predict the date of $90 \%$ bloom for each variety, site and year. Temperature model results were compared to averaged actual dates of $90 \%$ bloom by site and variety used to predict bloom timing (Calendar Model). The relationship between bloom length in days and $\mathrm{GDH}^{\circ}$ during bloom and the relationship between bloom length, $\mathrm{GDH}^{\circ}$ during bloom and final crop yields were also evaluated. The average error in predicting the $90 \%$ bloom date for both Nonpareil and Mission was smaller using the Calendar Model compared to the four temperature pattern models. The Chill Portion model did not have significantly higher average error in predicting the date of $90 \%$ bloom than the Calendar model in Nonpareil. The Chill Unit and Chill Portion models had smaller errors in predicting $90 \%$ bloom date than the Chill Hour or $\mathrm{GDH}^{\circ}$ model in Mission. $\mathrm{GDH}^{\circ}$ during bloom was positively correlated with bloom length. $\mathrm{GDH}^{\circ}$ during the first four days of Nonpareil bloom was significantly correlated with crop yields, with each additional $\mathrm{GDH}^{\circ}$ during bloom correlated with a $0.4 \mathrm{lbs}$./tree increase in crop yield. Further research is needed on specific temperature thresholds and their relationship to physiological changes during almond bloom and pollination. The practice of monitoring chilling and heat accumulation will allow growers to anticipate bloom, prepare to optimize bee activity during bloom, and plan for possible crop yield variations due to adverse weather conditions during bloom in almonds.
\end{abstract}

Keywords: Almonds, Tree Physiology, Flowering, Yield, Growing Degree Days, Chilling Requirement 


\section{ACKNOWLEDGEMENTS}

I would like to thank the many people who have helped guide me to Cal Poly and through the process of completing this project. Firstly, I would like to express my gratitude to Farm Advisor Joe Connell and Bob Curtis, Senior Manager of Production Research and the Almond Board of California, who were instrumental in inspiring, formulating and funding this project. This project would not have been possible without their gracious generosity and support.

I would like to sincerely thank Dr. Mary Pedersen, my Graduate Advisor, who provided many meetings' worth of much needed advice, confidence and encouragement throughout my time as a Master's student. I would like to thank Dr. Mark Shelton, who along with Dr. Pedersen, was instrumental in my arrival at Cal Poly and has provided additional counsel to me. I am very grateful to Dr. Steven Rein, for his time and expertise in the statistical design and analysis phases of this project. I would like to express my appreciation for the members of my committee, Dr. Garner and Dr. Wong, for contributing their knowledge of perennial tree crops and plant physiology to this project.

A special thank you to my mother Tamara, father Craig, step-father Ray, and my best friend and boyfriend Chris for their unending patience, positivity and love throughout this journey.

Thank you to my invaluable friends in San Luis Obispo for their constant support and mentorship. Most importantly I would like to thank God for His strength, stamina and purpose in completing this thesis project. 


\section{TABLE OF CONTENTS}

$\begin{array}{lll}2 & \text { Page }\end{array}$

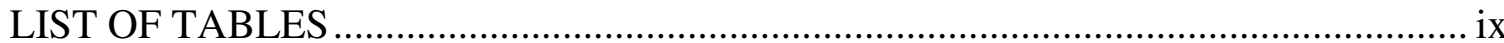

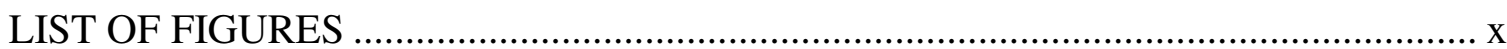

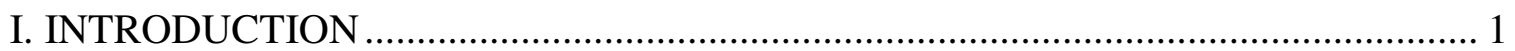

Objective 1. Evaluate correlations between temperature patterns prior to bloom and

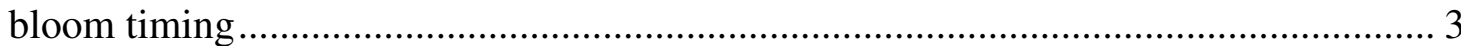

Objective 2: Evaluate correlations between temperature patterns during bloom and

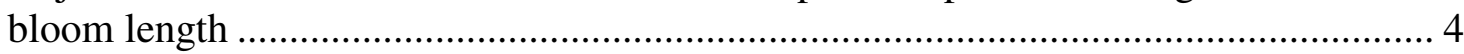

Objective 3: Evaluate correlations between the length of bloom, temperature patterns during bloom, and corresponding yields....................................................................... 4

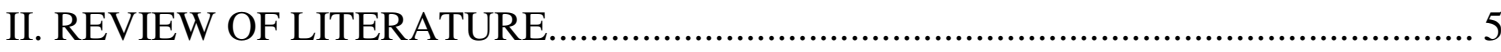

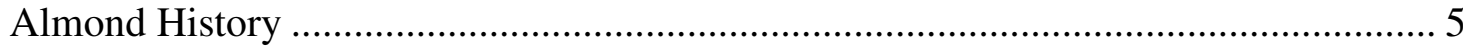

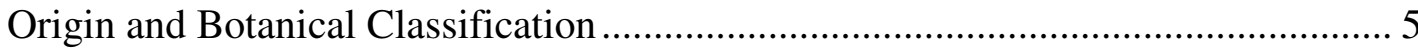

California Almond Production.......................................................................... 8

Orchard Planning, Design and Development......................................................... 12

Seasonal Processes ................................................................................... 14

Almond Growth and Development ........................................................................ 17

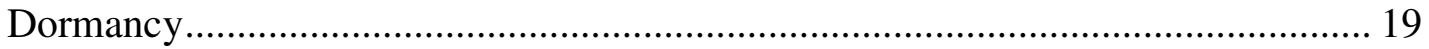

Temperature and Growth ............................................................................... 24

Almond Bloom........................................................................................... 30

Annual Reproductive Cycle ............................................................................ 30

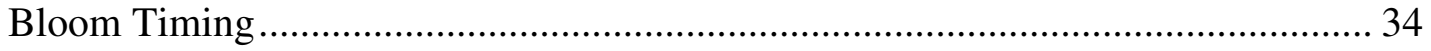

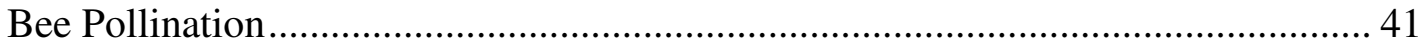

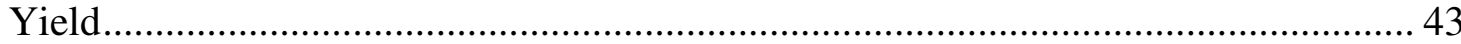

Fruit Set and the Effective Pollination Period (EPP) ................................................. 44

Pollen Grain Germination, Pollen Tube Growth and Ovary Fertilization................. 45

Fruit and Nut Development ............................................................................. 46

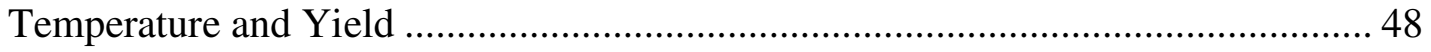

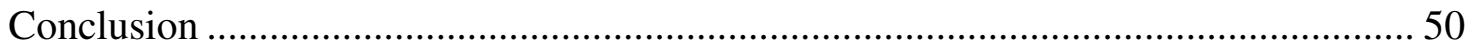

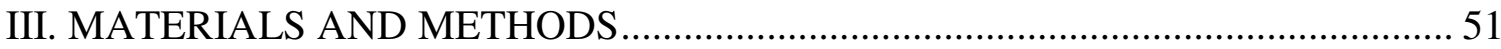

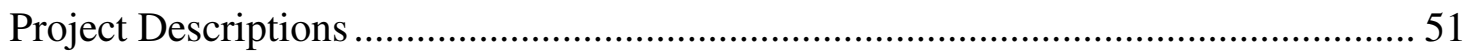

Regional Almond Variety Trials (1993-2006 RAVT) …………………………….... 51

Almond Bloom Project .................................................................................... 52

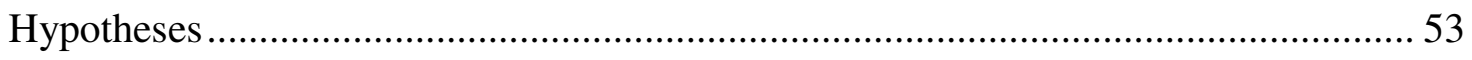


Objective 1. Evaluate correlations between temperature patterns prior to bloom and bloom timing.

Objective 2: Evaluate correlations between temperature patterns during bloom and bloom length 53

Objective 3: Evaluate correlations between the length of bloom, temperature patterns during bloom, and corresponding yields. 54

Differences between Nonpareil and Mission ........................................................... 54

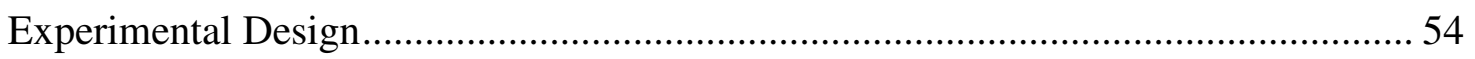

Objective 1. Evaluate correlations between temperature patterns prior to bloom and bloom timing

Objective 2: Evaluate correlations between temperature patterns during bloom and bloom length

Objective 3: Evaluate correlations between the length of bloom, temperature

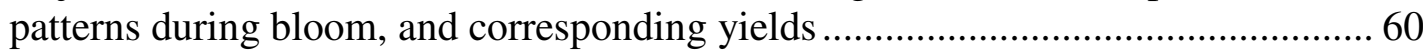

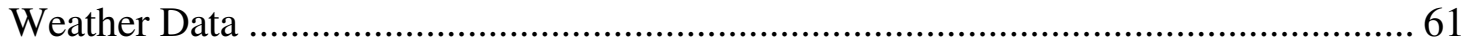

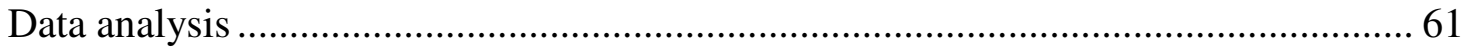

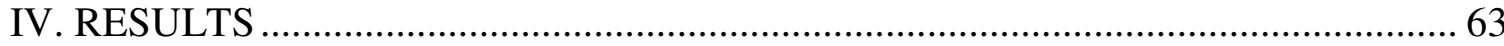

Objective 1. Evaluate correlations between temperature patterns prior to bloom and

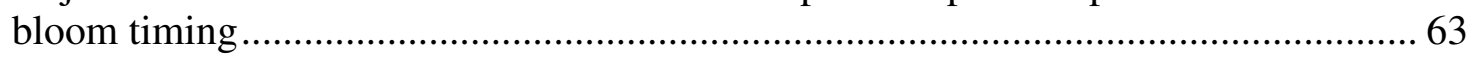

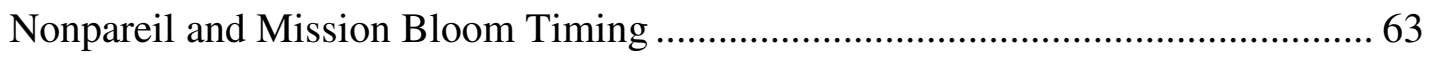

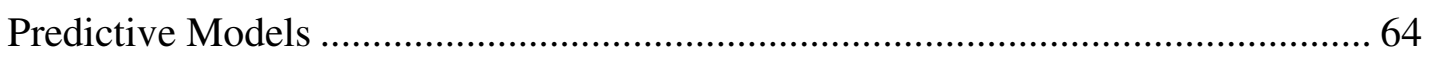

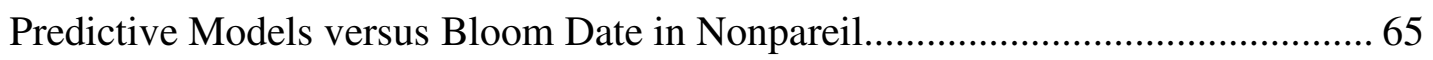

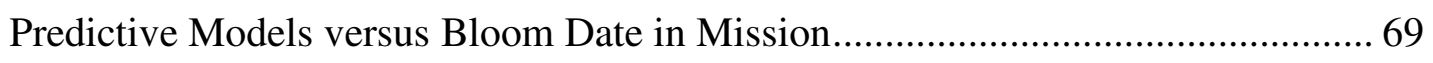

Objective 2: Evaluate correlations between temperature patterns during bloom and

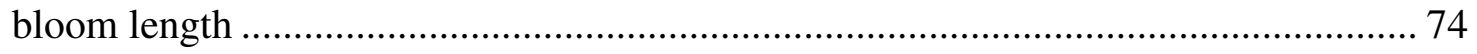

Objective 3: Evaluate correlations between the length of bloom, temperature patterns

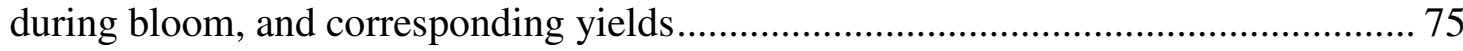

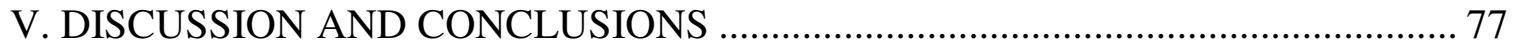

Objective 1. Evaluate correlations between temperature patterns prior to bloom and

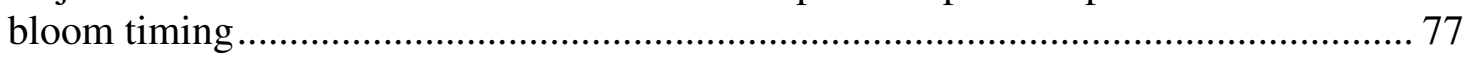

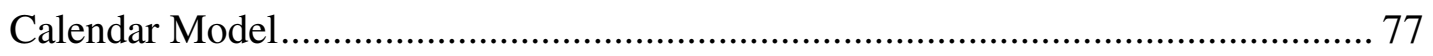

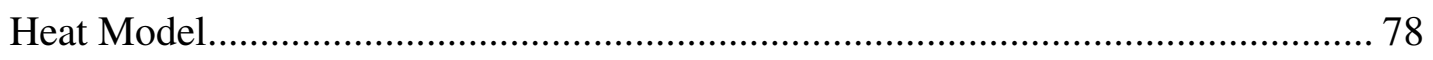

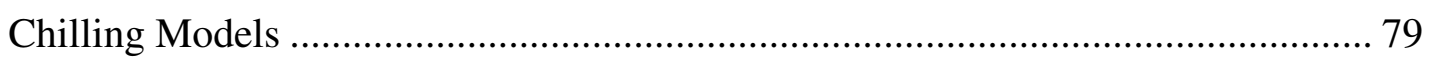

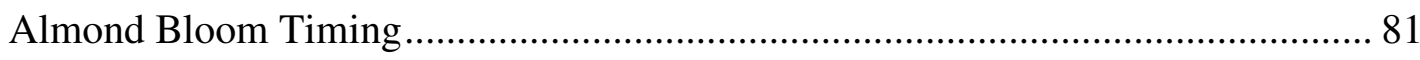

Objective 2: Evaluate correlations between temperature patterns during bloom and

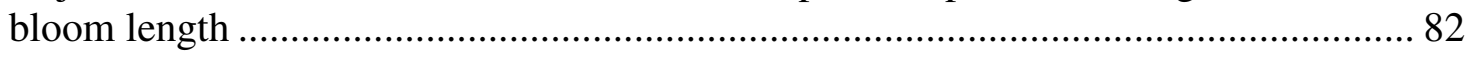


Objective 3: Evaluate correlations between the length of bloom, temperature patterns

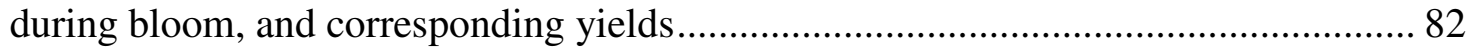

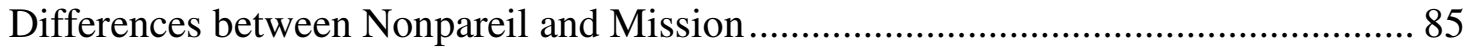

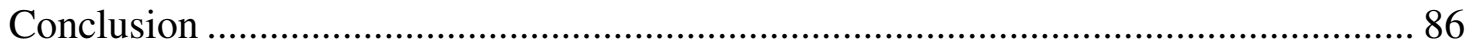

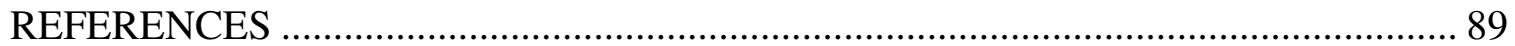

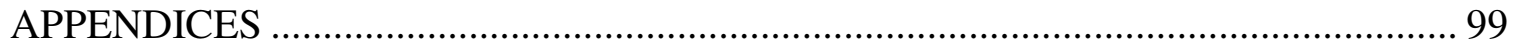

A. Butte County RAVT Bloom Data for 1996 (top) and 2006 (bottom)..................... 99

B. San Joaquin County RAVT Bloom Data for 1996 (top) and 2006 (bottom ......... 100

C. Kern County RAVT Bloom Data for 1996 ..................................................... 101

D. Kern County RAVT Bloom Data for 2006 .................................................... 102

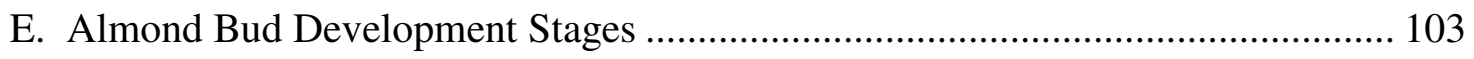

G. Nonpareil Raw Data....................................................................................... 105

H. Nonpareil Raw Data....................................................................................... 105

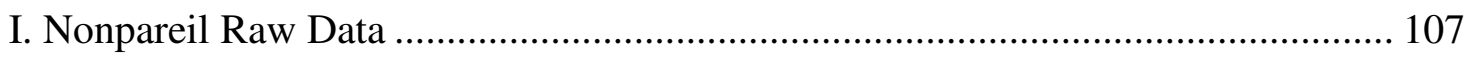

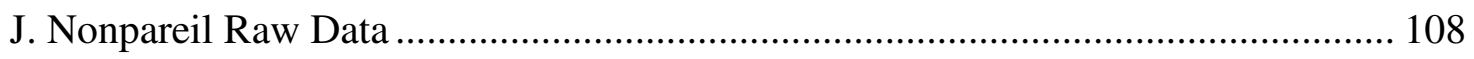

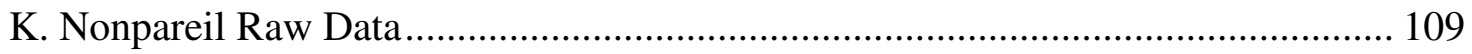

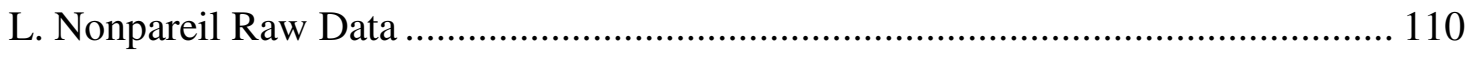

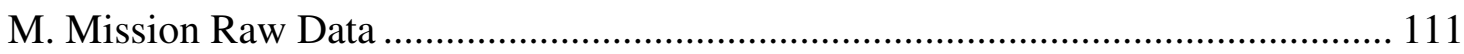

N. Mission Raw Data ........................................................................................ 112

O. Mission Raw Data ........................................................................................ 112

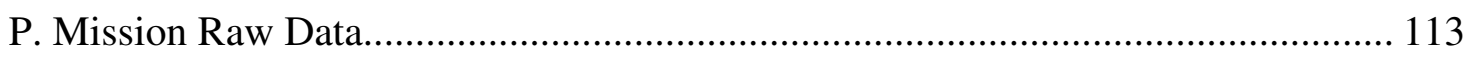

R. Mission Raw Data ....................................................................................... 115 


\section{LIST OF TABLES}

Table

Page

1. Common plant growth regulators and their functions. 18

2. Temperature ranges and their corresponding values in weighted Utah Chill Units using the Utah Model

3. Calculated chill requirements for Nonpareil and Mission in the form of Chill

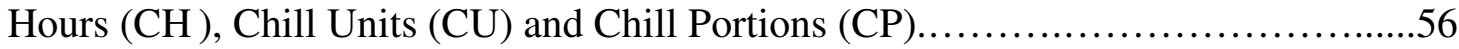

4. Mean dates of $90 \%$ bloom for Nonpareil and Mission by County.............................64

5. Mean standard errors from comparing the capacity of the Calendar Model vs. Chill Hour, Chill Unit, Chill Portion and Heat Models to accurately predict the date of $90 \%$ bloom in Nonpareil for the years 1996-2006 in Butte, San Joaquin and Kern Counties

6. Mean standard errors from comparing the capacity of the $\mathrm{CH}$ vs. $\mathrm{CP}$ and the $\mathrm{CU}$ vs. CP Models to accurately predict the date of $90 \%$ bloom in Nonpareil for the years 1996-2006 in Butte, San Joaquin and Kern Counties.

7. Mean standard errors from comparing the capacity of the Calendar Model vs. $\mathrm{CH}$, CU, CP and Heat Models, and CP vs. CH, CP Models to accurately predict the date of 90\% bloom in Mission for the years 1996-2006 in Butte, San Joaquin and Kern Counties. .70

8. Mean standard errors from comparing the capacity of the $\mathrm{CH}$ vs. $\mathrm{CP}$ and the CU vs. CP Models to accurately predict the date of $90 \%$ bloom in Mission for the years 1996-2006 in Butte, San Joaquin and Kern Counties...

9. Mean bloom length in Nonpareil and Mission in days by County....................74

10. Mean Nonpareil and Mission yield (lbs./tree) by County.......................... 75

11. Multiple Regression Analysis of yield versus bloom length......................76

12. Multiple Regression Analysis of yield versus $\mathrm{GDH}^{\circ}$ during the first four days of bloom. 


\section{LIST OF FIGURES}

Figure

Page

1. Origins of several species of Prunus (Martínez-Gómez, et al., 2003)..................7

2. Left, California almond bearing acreage. Right, California almond production, 1999-2010 (NASS, 2011)................................................... 10

3. Right, Nonpareil and left, Mission almond varieties with characteristic almond shell shape and kernels (California, 2010c)

4. Annual dormant phases in almonds. Adapted from Faust 1989 (Faust, 1989a;

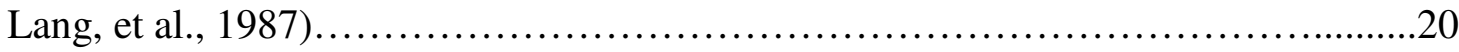

5. Two year almond growth cycle (Kester \& Gradziel, 1996)..........................21

6. Honey bee colonies are placed at $1 / 4$ acre intervals in almond orchards to promote successful cross pollination

7. Observed yearly dates of $90 \%$ bloom in Nonpareil for Butte, Manteca (San Joaquin) and Kern Counties

8. Observed yearly dates of $90 \%$ bloom in Mission for Butte, Manteca (San Joaquin) and Kern Counties.

9. Butte County predicted dates of $90 \%$ Nonpareil bloom using the $\mathrm{CH}, \mathrm{CU}, \mathrm{CP}$, Calendar and Heat models compared with the actual dates of $90 \%$ bloom.

10. San Joaquin County predicted dates of $90 \%$ Nonpareil bloom using the $\mathrm{CH}, \mathrm{CU}, \mathrm{CP}$, Calendar and Heat models compared with the actual dates of $90 \%$ bloom.

11. Kern County predicted and actual dates of $90 \%$ Nonpareil bloom using the $\mathrm{CP}, \mathrm{CH}$ and $\mathrm{CU}$ Models....

12. Butte County predicted dates of $90 \%$ Mission bloom using the $\mathrm{CH}, \mathrm{CU}$, $\mathrm{CP}$, Calendar and Heat models compared with the actual dates of $90 \%$ bloom

13. San Joaquin County predicted dates of $90 \%$ Mission bloom using the $\mathrm{CH}$, CU, CP, Calendar and Heat models compared with the actual dates of $90 \%$ bloom

14. Kern County predicted dates of $90 \%$ Mission bloom using the $\mathrm{CH}, \mathrm{CU}, \mathrm{CP}$, Calendar and Heat models compared with the actual dates of $90 \%$ bloom .73

15. Scatterplot of Bloom Length versus $\mathrm{GDH}^{\circ}$ during bloom for Nonpareil........ .74 
16. Scatterplot of Bloom Length versus $\mathrm{GDH}^{\circ}$ during bloom for Mission..................75 


\section{CHAPTER}

\section{INTRODUCTION}

Almonds (Prunus dulcis) are a nutrient rich nut crop enjoyed by cultures all over

the world. A one ounce serving of almonds contains significant amounts of vitamins and minerals, protein, unsaturated fat and fiber (California, 2010a, p. 17). Research suggests that when 1.5 ounces of almonds are included in a balanced diet, blood lipid and cholesterol levels are reduced and may decrease chances of heart disease (Jenkins, Kendall, Marchie, Parker, Connelly, Qian \& Spiller, 2002). The versatile nut can be incorporated into virtually any dish, and one hundred percent of the U.S. almond supply is produced in California, making almonds one of the most valued agricultural commodities produced by the state (California, 2010a, p. 23). For this reason, factors that affect final production yields have a huge impact on almond supply, market prices and California's agricultural economy.

Production yields have historically been an issue in tree crops (Tromp, 1986) and remain a concern in almonds. Multiple field factors influencing crop harvest and final yield have been identified. Year-to-year variations in crop production have been linked to weather conditions before, during, and after almond bloom. Wind and low temperatures affect bee activity and pollination (Dennis, 1979), and frosts can reduce the number of buds, flowers and fruits (Rodrigo, 2000). Rain or high relative humidity can cause pollination failures and promote fungal diseases during bloom (Gradziel \& Weinbaum, 1999). Temperatures following pollen shed affect pollen tube growth and the effective pollination period (Williams, 1970). Tracking temperature trends leading up to 
and occurring throughout almond bloom assists growers and horticulturists in anticipating frost protection needs and bee activity management during bloom.

Almonds are one of the first fruit and nut trees to bloom in early spring, causing leaf and flower buds to be exposed to freezing temperatures that can impede or kill vital tissues (Kester \& Gradziel, 1996). Bee keepers and growers must plan to optimize hive population strength and activity during peak bloom dates (Thorp, 1996).

The purpose of this project was to investigate the relationship between temperatures preceding almond bloom and bloom timing, between temperatures during bloom and bloom length, and to investigate the relationship between temperatures during bloom, bloom length and harvest yields.

Data utilized for this empirical study was based on observational data taken from the 1993-2006 Regional Almond Variety Trials (RAVT) in Butte, San Joaquin and Kern Counties, funded by the Almond Board of California and industry constituents. The trials contained over 30 different almond varieties, but for the purposes of this study, only the Nonpareil and Mission (Texas) variety data were used because Nonpareil is the most popular industry variety across the state and Mission is a dominant late blooming pollinator variety (Asai, Micke, Kester \& Rough, 1996).

Yearly Nonpareil and Mission bloom data were gathered from progress reports posted online (Appendix A-E). Information on site (Butte, San Joaquin or Kern Co.), variety (Nonpareil and Mission), year (1996-2006), date of 10\% bloom, date of $90 \%$ bloom and yield (lbs./tree) was collected from these reports. This data was compared with temperature data taken from the California Irrigation Management Information System (CIMIS) website, using the weather stations located nearest to RAVT orchard 
locations in Butte, San Joaquin and Kern Counties. Temperature data was converted into Chilling Hours (CH), Utah Chilling Units (CU), Chilling Portions (CP) and Growing Degree Hours $\left(\mathrm{GDH}^{\circ}\right)$ using the Chilling Hour Model (Weinberger, 1950), Chill Unit (Utah) (Richardson, Seeley \& Walker, 1974) and the Chill Portion ( Dynamic) Models (Erez, Fishman, Gat \& Couvillon, 1988; Fishman, Erez \& Couvillon, 1987a 1987b).

The objectives of this study were to (1) correlate almond varietal bloom timing with temperature variables prior to bloom, (2) correlate almond varietal bloom length in days with temperature variables during bloom and (3) correlate temperature variables and almond varietal bloom length in days with final crop yields (acres/tree).

Corresponding hypotheses to each objective were as follows:

\section{Objective 1. Evaluate correlations between temperature patterns prior to bloom and bloom timing}

Hypothesis 1A. A specific amount of cold temperatures below $45^{\circ} \mathrm{F}\left(7.2^{\circ} \mathrm{C}\right)$ (chilling requirement) in the form of $\mathrm{CH}, \mathrm{CU}$ or $\mathrm{CP}$ followed by a specific amount of warm temperatures above $40^{\circ} \mathrm{F}\left(7.2^{\circ} \mathrm{C}\right.$ ) (heat accumulation) in the form of $\mathrm{GDH}^{\circ}$ prior to almond bloom will have a significant relationship with bloom timing date for each year, variety and site.

Hypothesis 1B. A combination of chilling and heat accumulation prior to bloom will have a greater influence on almond bloom timing than either calendar date or solely heat accumulation prior to bloom for each year, variety and site.

Hypothesis 1C.. An earlier date on which each variety reached their chilling requirement will result in an earlier bloom for each year, variety and site. 
Hypothesis 1D. A greater amount of $\mathrm{GDH}^{\circ}$ in the two weeks prior to bloom will result in an earlier bloom for each year, variety and site.

\section{Objective 2: Evaluate correlations between temperature patterns during bloom and}

\section{bloom length}

Hypothesis: A greater amount of $\mathrm{GDH}^{\circ}$ during bloom will result in a significantly abbreviated bloom length for each year, variety and site.

Objective 3: Evaluate correlations between the length of bloom, temperature patterns during bloom, and corresponding yields

Hypothesis: A greater amount of $\mathrm{GDH}^{\circ}$ during bloom will result in below average crop yields, when controlling for pest pressure for each year, variety and site.

For differences between Nonpareil and Mission: the Mission variety will have a significantly larger amount of chilling and heat accumulation requirements than Nonpareil at each year and site (Bradley \& Maurer, 2002)

A greater understanding of the factors affecting bloom timing and length and the relationship between bloom and nut set will allow growers to understand almond bloom timing; prepare to optimize bee activity during bloom and plan for crop losses during bloom. 


\title{
CHAPTER
}

\section{REVIEW OF LITERATURE}

The almond (Prunus dulcis) is one of the oldest tree crops known to the Asian and European continents, with the earliest evidence of cultivation dating around 2000 B.C. (Kester, Gradziel \& Grasselly, 1991, p. 701). Research suggests that almonds evolved from wild relatives that can be found ranging across southwest and central Asia from Turkey and Syria into the Caucasus Mountains, through Iran and into the deserts of the Tian-Shan and Hindu Kush Mountains of Tajikistan, Uzbekistan and Afghanistan.

Almonds and their wild relatives are well adapted to growing on marginal soils under hot, dry summer and mild, cool winter conditions that are typical of Mediterranean climates (Gradziel, 2009, pp. 5-11; Kester, et al., 1991).

\begin{abstract}
Almond History
Almonds are a small to medium sized deciduous fruit tree within the rose (Rosaceae) family. The tree is commercially grown to 10-15 feet in height and remains in production for 50 years or more, depending on growing site and conditions (Kester, Martin \& Labavitch, 1996). Leaves are linear or ovate with serrated margins (Rieger, 2006). It shares the genus Prunus with other tree fruits such as peaches, plums, cherries, and apricots (Kester \& Gradziel, 1996; Kester, et al., 1991).

\section{Origin and Botanical Classification}

The almond fruit are botanically classified as a drupe with a pubescent exocarp (skin), a thin, fleshy mesocarp (hull) and a hardened endocarp (shell). The kernel contains an embryo surrounded by a pellicle, composed of a seed coat, nucellus and endosperm remnants (Kester \& Ross, 1996). Almonds are differentiated from other
\end{abstract}


Prunus species by its dry and leathery mesocarp which dehisces at maturity (Gradziel, 2009; Kester \& Gradziel, 1996).

This difference between almonds and other Prunus species has caused difficulties in classifying the genera. Almonds were originally known in European literature as Prunus amygdalus (from Latin amygdalus, meaning "almond"), but is now widely scientifically accepted as Prunus dulcis (from Latin dulcis, meaning "sweet"). This classification groups the crop with other Prunus species and their similar genetics and morphology (Browicz \& Zohary, 1996; Gradziel, 2009; Kester \& Gradziel, 1996).

Evolution. Taxonomists argue that the almonds' evolution of distinctive botanical structures in arid environments separate from other Prunus species is a cause for a distinct genus, Amygdalus communis (Browicz \& Zohary, 1996). On the other hand, molecular studies have shown that almonds are genetically very similar to peach (Prunus persica), suggesting that both originated from the same original species but evolved separately. Modern varieties of cultivated almonds can be easily intercrossed with wild types, adding credibility to the latter theory.

Researchers speculate that due to mountain range formation that separated the Eastern and Western Asian continent around 10 million years ago, the peach developed under a warmer, wetter climate at lower elevations in Eastern Asia while almonds evolved under severe, arid and variable conditions in the central and western regions (Kester \& Ross, 1996; Martinez-Gomez, Sanchez-Perez, Vaknin, Dicenta \& Gradziel, 2005) (Figure 1). 


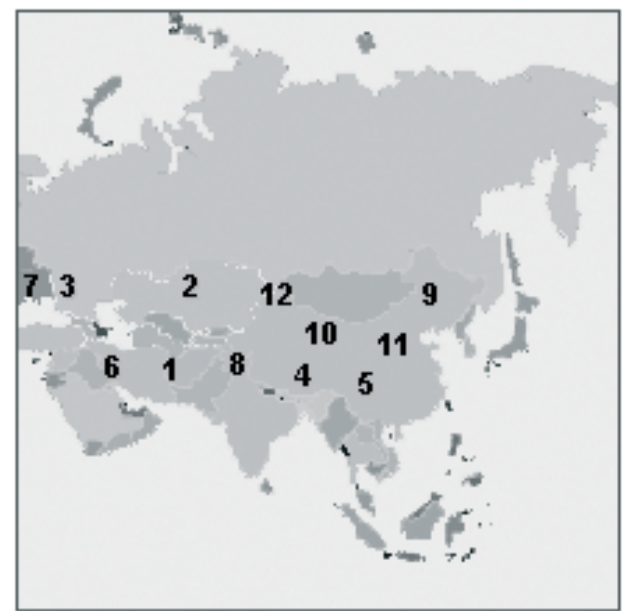

1. P. argentia

2. P. bucharica

3. P. fenziana

4. P. davidiana

5. P. persica

6. P. scoparia

7. P. webbil

8. $P$. dulcis

9. P. armeniaca

10. $P$. manshuric

11. P. japonica

$12 P$. avim

Figure 1. Origins of several species of Prunus (Martínez-Gómez, et al., 2003).

This evolution under unstable conditions is thought to have contributed to almonds' extensive genetic diversity. The species adapted to a variety of climates, has a deep rooting habit, and has broadly distributed wild relatives that are well adapted with low chilling requirements for early bloom, rapid early shoot growth and a high tolerance for summer heat and drought (Gradziel, 2009; Kester \& Gradziel, 1996); additionally, taxonomists speculate that the erratic climates contributed to outbreeding and resulted in almonds' characteristic self-incompatibility (Browicz \& Zohary, 1996).

Dispersal. Native almond relatives are known for their bitter kernels and high levels of glucoside amygdalin, which hydrolyzes to benzaldehyde and cyanide when the kernels are injured, chewed or crushed (Zohary \& Hopf, 1993, p. 186). Early cultivation began when growers differentiated sweet kernelled landraces from the bitter wild types (Kester \& Ross, 1996).

The nuts of early almond cultivars, also known as "Greek nuts," [Prunus dulcis (Mill.) D.A. Webb L, syn. Prunus amygdalus Batsch., Amygdalus communis L., Amygdalus dulcis Mill.], were easily transported and stored, and were prized for their 
delicious seed and high oil content. The kernels contain 50-55\% oleic and lineoleic fatty acids, and 20\% protein (Kester, Kader \& Cunningham, 1993, p. 123; Kester \& Ross, 1996).

Travelers along the Silk Road soon began disseminating the several cultivars of differing morphology and origin across the Asian continent, making it an important commodity to emerging civilizations. Almonds were dispersed in three phases; East across Asia, West through Mediterranean region and North Africa, and eventually to California (Browicz \& Zohary, 1996; Kester \& Gradziel, 1996; Kester, et al., 1991).

With the development of trade routes directed east to China, India and Pakistan, and west to Turkey, Israel and Syria, almonds' cultivation quickly spread via global commerce from its origin in central Asia. By 2000 B.C., almonds were mentioned in Hebrew literature and by 450 B.C., almonds' cultivation had established in Spain, Portugal, Greece, Morocco, Tunisia, Turkey, France and Italy (Gradziel, 2009; Kester, et al., 1991). Early almond orchards were planted on hillsides to avoid frost and dryland farmed on marginal soils (Kester \& Ross, 1996). These methods continue to be used in many Asian and European regions today (Browicz \& Zohary, 1996) (Gradziel, 2009).

\section{California Almond Production}

Spanish Franciscans brought almonds to California in the mid-1700s and attempted to establish tree stands at Catholic Mission sites along the coastal mountain ranges. These almond plantings were largely unsuccessful due to poor soils and cooler climates (Browicz \& Zohary, 1996). 
The earliest documented commercial orchard was established in El Dorado County in 1843 (Butterfield, 1963, p. 2). Growers initially planted French varieties and failed to understand cross pollination techniques, resulting in poor and inconsistent yields. This prompted the U.S. Plant Introduction Station to fund imported European varieties (Browicz \& Zohary, 1996).

The need for improved, reliable varieties inspired A.T. Hatch of Suisun, California, to plant around 2,000 seedlings in 1879 (Kester \& Ross, 1996). He selected four cultivars from his orchard and named them Nonpareil, IXL, Ne Plus Ultra and La Prima. Another late blooming selection selected from French seedlings was brought from, and named, Texas and later reclassified as Mission. These, when planted along with grower Wilson Treat of Colusa's Peerless variety, became the best yielding and most commonly planted cultivars across California (Browicz \& Zohary, 1996).

Presently, almond acreage continues to expand dramatically. By 2000, California had become the only commercial U.S. producer of almonds and the leading supplier of almonds in the world and all aspects of its production are mechanized (Boriss \& Brunke, 2005; California, 2010a). Present day state almond production extends from the southern San Joaquin Valley to the northern Sacramento valley.

In 2010, California almond acreage was estimated at 740,000 acres with Kern and Fresno Counties accounting for over $40 \%$ of the crop (NASS, 2010) (Figure 2). California almonds make up more than $80 \%$ of the world's total almond exports with an estimated commodity value of $\$ 1.89$ billion (Matthews, Gabrielyan \& Sumner, 2008). 

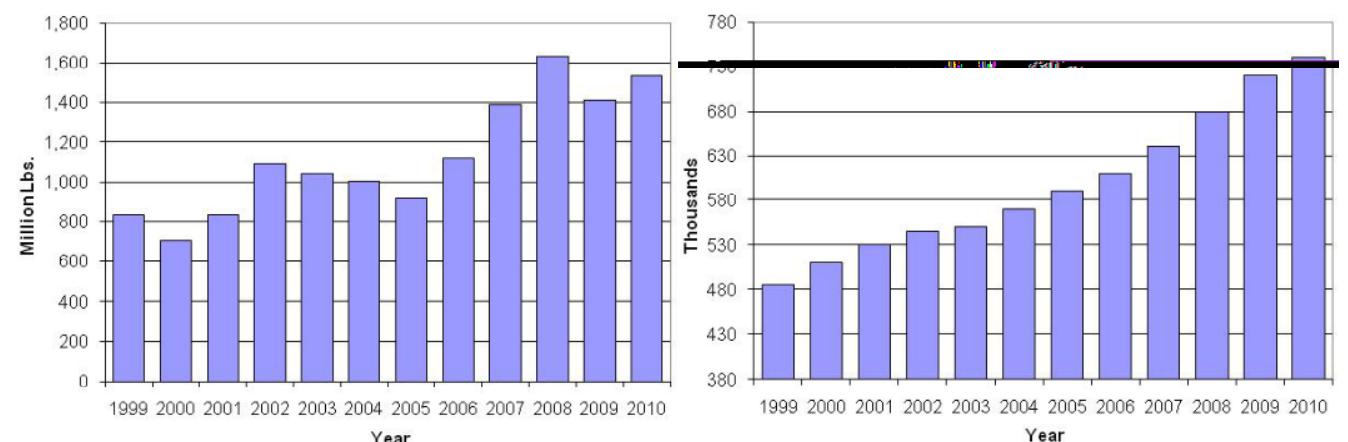

Figure 2. Left, California almond bearing acreage. Right, California almond production, 1999-2010 (NASS, 2011).

Today, California almonds are shipped to over 90 countries abroad (Boriss \& Brunke, 2005). The 2010 harvest averaged 2,230 pounds per acre and produced 1.65 billion pounds of almonds (California, 2010a; NASS, 2011) (Figure 2). In 2011, almonds remain the leading California agricultural export and US horticultural export (Browicz \& Zohary, 1996; California, 2010a; Perez \& Pollack, 2005; Western Farm Press, 2010) .

Varieties. Successful almond production depends on variety selection by the grower. Varieties must be specifically selected to match a growing site's soil conditions and local pest and disease pressures. Varieties (or cultivars) may vary in yield quantities, developmental timing and growth habit. Varieties differ in their response to cooler or warmer temperatures during the dormant period. Knowledge of a variety's climatic needs is of the most importance when selecting varieties for a new orchard.

The nut of an almond cultivar can differ by characteristic shapes, sizes, pubescence and retention of the pistil remnants and suture lines (Figure 3). In his USDA Technical Bulletin (1925), Milo N. Wood described four identifying characteristics for different varieties: ventral split, opening on one side; ventral and dorsal split; four-way split; and dorsal split (Wood, 1925). The mature hull varies in thickness, weight and final fruit proportion as well (Gradziel, 2009; Kester \& Gradziel, 1996; Kester \& Ross, 1996). 
Over thirty varieties of almonds are grown in California. Nonpareil remains the most popular variety with over 250,000 planted acres while Carmel, Butte, Monterey and Padre follow, rounding out the top 5 varieties in acreage (California, 2010a). Varieties are grouped into early, mid- and late blooming genotypes.

Popular early bloomers include Jordanolo, Ne Plus Ultra, Peerless and Sonora. Nonpareil is a mid-blooming variety, along with Aldrich, Carmel, Fritz, Price, Solano and Woods Colony. Late blooming varieties include Butte, Monterey, Livingston, Mission (also known as Texas), Padre, Ruby and Thompson (Asai, et al., 1996).
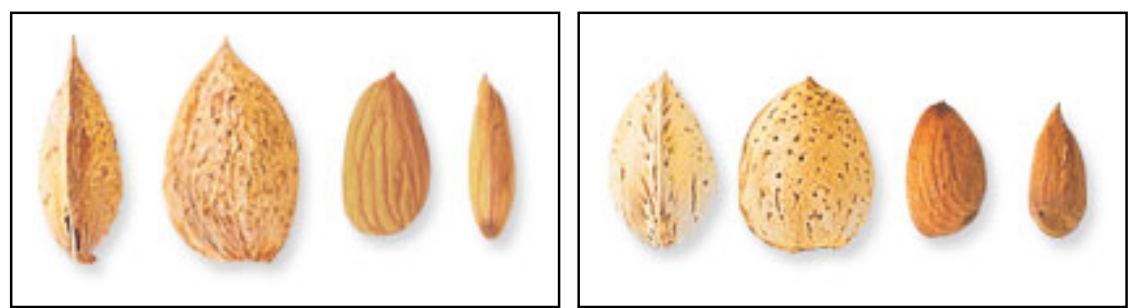

Figure 3. Right, Nonpareil and left, Mission almond varieties with characteristic almond shell shape and kernels (California, 2010c).

Marketing. Growers, processors and handlers in the almond industry rely on successful marketing in order to increase popularity in new markets and sustain consistent consumer demand. For the past three decades, Europe has been California's main export market. California's almond crop meets over 50\% of the demand in France, Italy and the Netherlands and supplies over two thirds of the market in Germany and Great Britain (Alston, Christian, Murua \& Sexton, 1993). To assist with maintaining market demand, the Almond Board of California has collaborated with growers to market California's almond crop on an international level. Collaborative efforts have resulted in new markets opening in Japan, India and China, allowing growers to enjoy relatively stable market prices despite an almost 500\% increase in average annual almond 
production over the past 30 years (Alston, et al., 1993; California, 2010a; Moulton, 1996).

Growers are responsible for offsetting revenue losses due to increased supply. Growers can increase their operating efficiencies by researching successful growing locations, varieties and orchard designs that will ultimately influence yield quality and quantity (Moulton, 1996). Irrigation, fertilization, pruning and pest control also play a role in the final crop price and salability.

\section{Orchard Planning, Design and Development}

With proper preparation and consistent management, an almond orchard may maintain full production for 20-25 years (Kester \& Gradziel, 1996). First, the grower must select a suitable orchard site by studying the soil and water profiles, soil type and nutrients, and pest populations (Hendricks, 1996). If a site is not ideal, growers can make plans for preplant site treatment and can ameliorate shallow soils, saline or alkali soils with careful management through the use of low volume irrigation systems, high quality water or soil amendments (Hendricks, 1996; Viveros, 2002).

An orchard site must be free of hardpans or stratified soils. Sites with hardpans can be modified by ripping to a depth of 4 or 5 feet and cross ripping at the tree site (Viveros, 2002). For soil type, almond orchards produce best on deep, well-drained soils with high nutrient content and low salinity. Orchards must be screened for nematode populations, especially root knot nematode (Meloidoegynes spp.) (Viveros, 2002).

Propagation. Almonds are propagated in nurseries prior to orchard establishment. Propagation ensures nuts are true to type . Nursery site selection and preparation are important to produce quality, disease free transplants. Rootstocks are 
propagated either as seedlings, hardwood or softwood cuttings. Rootstocks may be selected for their resistance to soilborne diseases or insect pests and tolerant of adverse soil conditions (Hendricks, 1996). Scions of almond varieties are chosen for their bearing qualities and budded or grafted onto rootstocks (Reil \& Sutter, 1996).

Planting. Almonds are self-incompatible, meaning varieties must be cross pollinated with other varieties to establish a viable commercial crop. Commercial almond cross pollination is completely reliant on honey bees for successful pollination and subsequent nut set (Thorp, 1996). Orchards are typically planted with 50\% Nonpareil and 25\% of each of two "pollinator" varieties (Hendricks, 1996). Growers must choose between having a slightly lower yield with only two varieties or the extra effort in management and harvest that goes with planting 3 varieties.

Tree varieties planted alternately in the same row will result in up to $15 \%$ increased yields (Hendricks \& Duncan, 2001). Trees are commonly planted at spacings of 20 by 22 feet ( 99 trees per acre) or 18 by 22 (110 trees per acre) (Viveros, 2002). Farm advisors often recommend an offset or diamond arrangement to maximize light capture and pollination efficiency. Growers either plant varieties that can be harvested together or, plant varieties that have distinctly different harvest dates interspersed around Nonpareil. This facilitates the harvest to help avoid mixing dissimilar nuts and maximize the likelihood for bloom overlap with Nonpareil (Duncan, 2010; Hendricks, 1996).

Planting must be ideally timed (January-February) to take advantage of lower ambient temperatures and delay leaf bud growth. Growers are advised to confine root prunings to removing broken or damaged roots. Prior to planting, roots may be treated to protect against crown gall disease. Trees are planted on raised berms to prevent 
Phytophthora infestation and promote good drainage around the base of the trees. After planting, tree roots must establish a strong rooting system as leaves push in spring (Hendricks, 1996; Viveros, 2002).

\section{Seasonal Processes}

Throughout the growing season, growers must be constantly on the lookout for potential problems and be diligent in fulfilling cultural responsibilities at each stage in the crop's annual cycle. Most problems arise from either weather or pest related situations and must be ameliorated by maintaining tree health and orchard sanitation (Duncan, Verdegaal, Holtz, Doll, Klonsky \& Moura, 2011). During the dormant season, winter sanitation is required to destroy overwintering Navel orangeworm larvae in the leftover nuts. Beginning in the third year, growers either shake trees by hand or hire custom operators to shake and dispose of mummy nuts (Duncan, et al., 2011; Reil, Labavitch \& Holmberg, 1996).

Rootstock suckering must be managed twice in the first year of orchard establishment and once in the second year to ensure good trunk development. Young trees must also be trained and pruned to maximize light capture and efficient growth (Connell, Asai \& Meith, 1996). Custom or contracted labor and operators are used for suckering and pruning and residue disposal (Duncan, et al., 2011).

Bee Management for Pollination. Beekeepers and their honey bees are a fundamental part of the success of the California almond industry. All major commercial varieties of almonds in California are self-unfruitful and require pollination by honey bees (Thorp, 1996). Bees are rented from beekeepers that facilitate pollination and monitor the colonies throughout the year (Delaplane \& Mayer, 2000). Keepers must be 
knowledgeable in honey bee colony biology and activities as well as adept in pollination techniques (Thorp, 1996).

The honey bee perennial social organization entity is the colony with its three castes: queen, workers (females) and drones (males). The caste and sex determine which bees carry out which activities. Egg laying and sex determination are carried out by the queen (Delaplane \& Mayer, 2000). Drones serve to fertilize the newly hatched queens during a brief mating period. The workers are responsible for all other colony activities, including nest construction, maintenance, defense, food gathering and processing, feeding newly hatched larvae and caring for the drones and queens (Burgett, Fisher, Mayer \& Johansen, 1984; Thorp, 1996).

There are approximately 15,000 to 50,000 workers per colony (Camazine, 1993). The workers' activities are determined by their age and are the only caste that leave the hive and visit flowers during food gathering activities. Around 3 weeks of age, worker bees are mature enough to become field bees and leave the hive to orient with their surrounding environment. Field bees spend the remainder of their lives foraging for pollen, nectar and water. Foraging starts in early spring when the temperatures increase and early flowers are in bloom (Thorp, 1996).

Research has determined a specific set of conditions that ensure bees are effectively foraging and pollinating, termed "good bee hours." These conditions are when temperatures are $55^{\circ} \mathrm{F}$ or higher with no rain and wind speeds under $15 \mathrm{mph}$ (Burgett, et al., 1984; Connell, 2011). Active foraging decreases at threshold temperatures and with cloudiness. 
Bees will travel several miles from their colony but research shows that most bees remain in close proximity (a few hundred yards) to their colony, especially if the colony is in a crop with high nectar and pollen contents, such as almond blossoms. Individual bees are known to consistently return to the same species of plant while foraging, and to favor almond trees in full bloom over competing flowering plants (Burgett, et al., 1984; Thorp, 1996).

A recent detriment to bee colonies countrywide has been the introduction of two parasitic mites, Acarapis woodi and Varroa destructor (Camazine, 1993). These mites have contributed considerably to honey bee colony collapse. Controlling mite populations among bee colonies is essential to maintain future populations (vanEngelsdorp, Foster-Cox, Frazier, Ostiguy \& Hayes, 2006).

Almond growers commonly sign service agreement contracts with beekeepers to ensure consistent pollination services and designate respective responsibilities. The contracts include hive availability dates, guaranteed colony strength, inspection fees, rental fees and payment schedules (Burgett, et al., 1984). Beekeepers will commonly require growers to agree to a no-spray insecticide ban while hives are in place (DegrandiHoffman, Thorp, Loper \& Eisikowitch, 1992).

Harvest and Processing. Almond harvest begins in August and usually lasts until late September. Proper harvesting methods and post-harvest handling are essential to achieving a high-quality end product. Farm Advisors recommend harvesting almonds as soon as the nuts have matured to avoid losses in quality due to navel orangeworm and associated aflatoxin contamination (California, 2010b; Reil, et al., 1996). 
Growers must first establish a clean, debris and moisture free orchard floor. Almonds are mechanically shaken from the tree, allowed to dry for a few days to a moisture content of 5-8\% and then swept into windrows (Reil, et al., 1996). The piles are mechanically picked up and sent by truck and trailers to the local huller/sheller operator. In periods of high crop processing, almonds are stockpiled and must be monitored to prevent moisture buildup and insect infestation. Hulled and shelled nuts are transported to be processed into the final consumer product (California, 2010c).

\section{Almond Growth and Development}

After nursery culture propagation and establishment in an orchard, the almond tree goes through a period of juvenility, or the non-flowering period after establishment. This period involves vegetative growth and development as the tree reaches maturity and full bearing potential (Faust, 1989b). Development is defined by cellular differentiation while growth refers to quantitative increases in size and volume. Several factors are necessary for these processes, including favorable environmental conditions, adequate nutrients and water. Growth is regulated by plant growth hormones or their precursors, which are in turn stimulated by external environmental factors (Taiz \& Zeiger, 2010, pp. 630-635).

Primary growth, or the extension of shoots or roots, enables young orchard trees to expand. The lifecycle of a tree goes through three stages: juvenility, maturity and reproductive. The maturity stage involves a transition from an entirely vegetative state to a tree with reproductive meristematic potential (Kester \& Gradziel, 1996). 
Once trees are mature, primary growth is responsible for the continual replacement of reproducing limbs (Kester \& Gradziel, 1996) . Trees begin bearing nuts 3-4 years after planting and reach full production at 6-7 years (Boriss \& Brunke, 2005).

The processes that make up development, cellular differentiation and elongation, are governed by a combination of a cell's location in a plant, neighboring cell processes, internally produced chemical compounds, or plant growth regulators (PGRs) and environmental stimuli which can include drought and pest pressure (Opik \& Rolfe, 2005a, pp. 176-179). Many new PGRs have recently been discovered and much of the complexity of interactions between precursors, PGRs themselves and gene expression is still unknown. Classic literature refers to five classes of PGRs; auxins, cytokinins, gibberellins (GA), abscisic acid (ABA) and ethylene (Taiz \& Zeiger, 2010, pp. 660-663).

These PGRs provide intercellular communication within a plant, promote and inhibit growth, and regulate levels in response to external environmental conditions. A short summary of the five classes and their known modes of action is listed (Opik \& Rolfe, 2005a, p. 187).

Table 1. Common plant growth regulators and their functions (Taiz \& Zeiger, $2010 \mathrm{p}$. 660)

\begin{tabular}{|l|l|}
\hline Plant Hormone & Function \\
\hline Abscisic acid & $\begin{array}{l}\text { Closes stomata, inhibits germination in seeds, promotes dehydration } \\
\text { tolerance and dormancy in seeds and buds }\end{array}$ \\
\hline Auxins & Apical dominance, cell enlargement, root growth, inhibits axillary buds \\
\hline Cytokinins & Cell division and enlargement, flowering senescence, inhibits auxin \\
\hline Ethylene & Stress is stimulated, root growth, senescence fruit ripening \\
\hline Gibberellins & $\begin{array}{l}\text { Cell elongation, promotes chilling tolerance and dormancy breaking in } \\
\text { seeds, flowering in long day plants (photoperiod response) }\end{array}$ \\
\hline
\end{tabular}

Growth includes morphogenesis, or plant organ formation. This involves three regions of cell expansion: shoot, cambial and root growth (Opik \& Rolfe, 2005a, pp. 164- 
187). The annual growth cycle of perennials follows an three phase S-shaped curve; slow initial growth in late winter and early spring, a period of rapid, almost exponential growth of vegetative axillary buds, vascular and cork cambium and root pericycle tissues in preparation for reproductive maturation and a slowing of final growth before temperatures and resources decrease in the winter (Opik \& Rolfe, 2005a, p. 171).

The tree also undergoes organ differentiation during the vegetative and reproductive development. The differentiation of apical meristems tissues into stem, leaf, bud or flower tissues is necessary for reproduction and survival (Kester \& Gradziel, 1996, p. 164; Opik \& Rolfe, 2005a).

\section{Dormancy}

Lang et al. (1987) completed an extensive review on dormancy, citing numerous issues surrounding the term and its use in research (Lang, Eary, Martin \& Darnell, 1987). These issues included misuse of the term, confusion with the definition and differences across species, varieties, location, and even language meanings. Significant issues have been raised with defining depth and duration of dormancy, as well as measuring dormancy requirements (see Chilling Accumulation) (Lang, et al., 1987).

To simplify classification and establish a universal research nomenclature, Lang et al. (1987) defined dormancy as "a temporary suspension of visible growth of any plant structure containing a meristem" (Lang, et al., 1987). He went on to describe three stages of dormancy; paradormancy, ecodormancy and endodormancy. These three dormant stages combine with one main growing stage to complete the annual life cycle in almonds (Kester \& Gradziel, 1996) (Figure 4). 
Almonds evolved in locations that frequently include unfavorable climactic conditions and dormant periods throughout the year. Trees evolved the ability to enter several states of dormancy to resist freezing and drought stress, and protect sensitive meristematic tissues (Anderson, Kesner \& Richardson, 1986). The annual cycle in almonds begins after buds are released from dormancy and begin sensing warming temperatures in early spring (Jackson, 1999, p. 82).

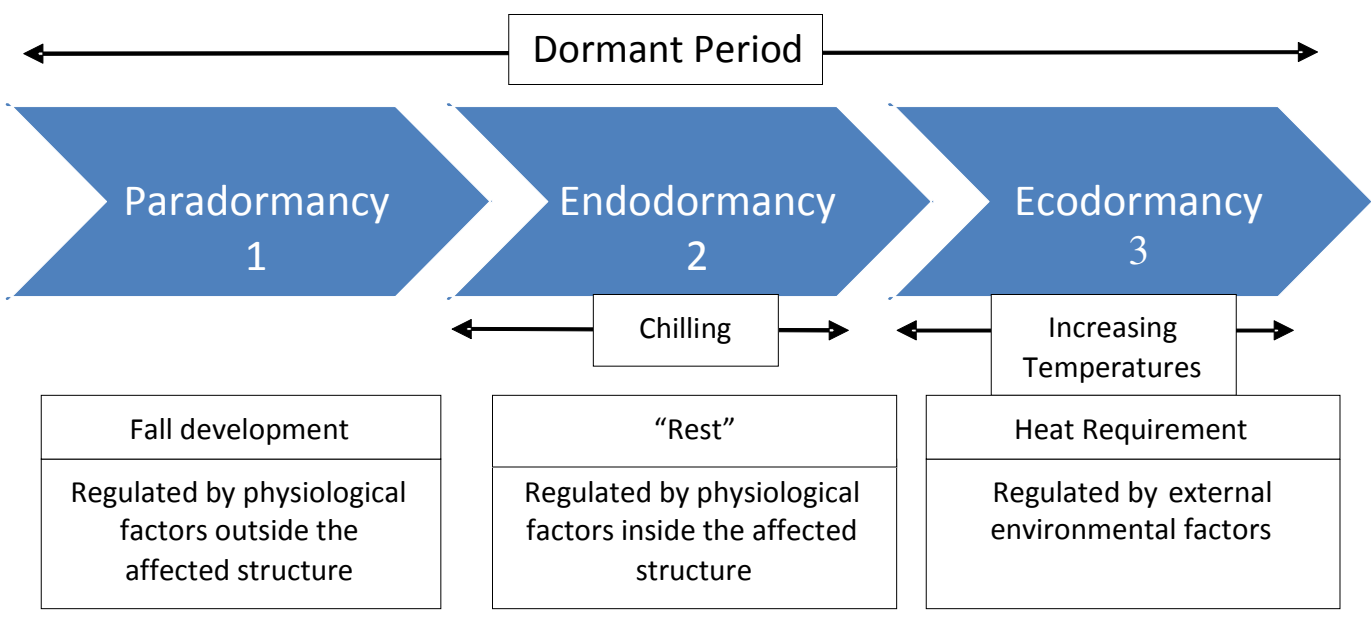

Figure 4. Annual dormant phases in almonds. Adapted from Faust 1989 (Faust, 1989a; Lang, et al., 1987).

Paradormancy. During the period from midsummer to early fall, vegetative buds increase in size and composition with a portion transitioning to flower buds. Research has found that vegetative buds enter a possibly high-temperature or drought stressinduced dormancy (Denisov, 1988), termed paradormancy, defined as growth cessation due to alternative resource needs (Kester \& Gradziel, 1996). Paradormancy can be broken by cultural methods and added inputs to the trees.

By mid-summer, lateral bud growth stops and trees establish apical dominance over lateral buds (Kester \& Gradziel, 1996). Trees gain height during this time and may 
often experience a second flush of growth in autumn if supplementary resources are available or growers employ pruning methods to force the trees to delay dormancy (Opik \& Rolfe, 2005a, p. 175).

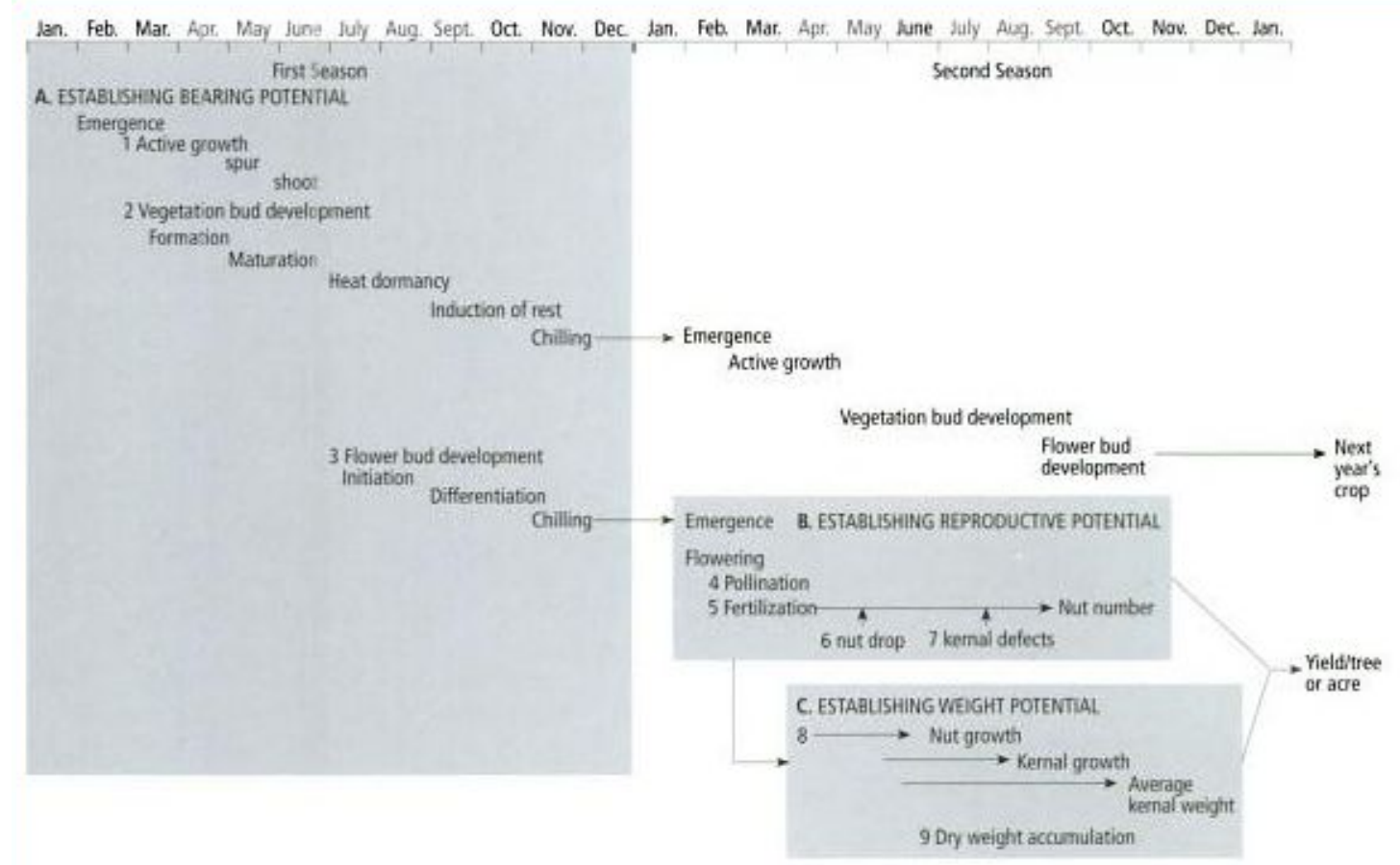

Figure 5. Two year almond growth cycle (Kester \& Gradziel, 1996).

Endodormancy. When temperatures cool in early fall, bud and shoot tissues begin to mature and develop endodormancy (rest period) in response to shortened days, reduced temperatures and certain management practices (Kester \& Gradziel, 1996).

Endodormancy occurs in mid-fall for almond trees and prevents buds from emerging until spring. The tree then undergoes a certain amount of cold ambient temperatures, termed a chilling requirement, before reaching rest completion and progressing to the next stage. Research has found that endodormancy, unlike ecodormancy, is internally 
controlled by physiological factors inside the primordial meristem that change in response to temperature and photoperiod (Erez, 2000a, p. 18; Lang, et al., 1987).

Various methods have been used to determine dormancy stages in trees and their corresponding temperature and photoperiod combinations. Researchers have morphologically dissected vegetative and floral buds to measure the primordial growth capacity and rate, as well as examined nucleic acid content and intracellular $\mathrm{pH}$ levels in buds (Bonhomme, Rageau, Richard, Erez \& Gendraud, 1999). The end-date of endormancy (termed "rest completion") in deciduous tree crops has been determined physiologically from growth chamber experiments on forced budbreak in apples and Prunus species (Ashcroft, Richardson \& Seeley, 1977; Viti \& Monteleone, 2011), including almonds (Egea, Ortega, Martinez-Gomez \& Dicenta, 2003). Other methods used for determining rest completion included morphological studies, shoot- tip culture and correlation models on almond flowering dates and temperatures during rest (Alonso, Anson, Espiau \& Socias i Company, 2005; Kester, Raddi \& Asay, 1977).

Research shows that little is understood about the effect of temperature on rest completion, but that this relationship involves hormones, drought stress and bud exposure to a genetically determined amount of cold ambient temperatures, termed the "chilling requirement." Faust (1989b) indicated that age of tree, soil fertility, soil moisture, PGR levels and fall temperatures combine to influence dormancy initiation (Faust, 1989b). Many cultivars will not grow and set fruit without meeting their chilling requirement (Kester \& Gradziel, 1996).

Ecodormancy. After buds are exposed to a specific amount of chilling in winter, they enter a state termed ecodormancy, or the "end of rest" where they are no longer 
regulated by internal plant growth regulators and can sense external factors, such as ambient warmth, lack of water or cold temperatures (Anderson, et al., 1986). Meristematic buds must accumulate a certain amount of warm temperatures before entering the next stage (Polito, 2009). Warm temperatures are measured in the industry accepted standard of growing degree days $\left(\mathrm{GDH}^{\circ}\right)$ or hours $\left(\mathrm{GDH}^{\circ}\right)($ Zalom, Goodell, Wilson, Barnett \& Bentley, 1983). The required amount of $\mathrm{GDH}^{\circ}$ for almonds is still being researched for most growing locations (Kester \& Gradziel, 1996; Kester, et al., 1996).

In late winter, almond trees undergo a comprehensive nutrient loading and storing process in preparation for vegetative bud break following bloom (Figure 5) (Faust, 1989b). During nutrient loading, gibberellins and cytokinins are highly concentrated in the dormant buds and facilitate starch conversion and cell growth and metabolism processes. Gibberellin is known to promote flowering in annual and perennial species (Opik \& Rolfe, 2005b, p. 186). These processes enable the trees' vegetative buds to grow and break through the bud scales in early spring. Green leaf tips are typically visible on trees by late January and spring growth is driven by carbohydrate stores from the previous year's growth (Kester, et al., 1996).

Growth Elongation and Leaf Expansion. From March to late June, Prunus species including cherry, peach and almond, have been observed to rapidly increase in bearing surfaces, weight and size (Chandler, 1942). This period is accompanied by increased protein, hormone and carbohydrate production in the buds, leading in rapid cell division and emergence of young shoots, consisting of nodes bearing a leaf from terminal and lateral buds. This industry- termed "grand period of growth" lasts longer in young 
trees (Opik \& Rolfe, 2005a, p. 171). Trees remain sensitive to favorable temperatures, nutrient influxes and pruning, which can stimulate further "flushes" in growth throughout the warm season (Kester, et al., 1996).

In mature bearing trees, the period of terminal shoot growth is shortened by various factors, including temperature, crop load, and nutrient and water availability. Short shoots 2 to 5 inches long, commonly known as spurs, grow from lateral buds or by secondary terminal extension of previous spurs. Spurs will develop flower buds later in the growth cycle (Kester, et al., 1996). Under favorable conditions, mature trees may produce lateral shoots that are up to 10 inches long and capable of setting heavy crop loads (Kester, et al., 1991; Martínez-Gómez, et al., 2003).

After the rapid growth periods of young and mature trees, growth ceases and the terminal bud establishes apical dominance. The stems thicken and harden, buds form in leaf axils and bud scales form. Terminal and axillary buds remain dormant from early summer to the next growing season (Jackson, 1999; Kester, et al., 1996).

\section{Temperature and Growth}

Alternating low and high temperatures are more favorable for plant growth than consistent temperatures. Temperature optimums, including lower and upper thresholds, differ across species and varieties, even individual plants, their specific organs and the age or developmental state of those organs (Opik \& Rolfe, 2005a, p. 166). Temperature optimums for a brief period in time may not be the same for a longer period of time (Opik $\&$ Rolfe, 2005a, p. 167).

Chilling Accumulation. The idea that deciduous trees must undergo a period of rest and accumulate cool temperatures in order to progress to the next stage of 
development has been known amongst growers since the late 1930s (Chandler \& Tufts, 1934). Deciduous trees often grow in climates with freezing temperatures and have developed adaptations to avoid internal frost damage during winter. From October to early November, trees will accumulate nutrients in stems and roots and are genetically programmed to endogenously (internally) suspend reproductive growth (quiescence) in preparation for dormancy (Erez, 2000a, p. 18).

Trees develop protective leaf and bud scales over vegetative and reproductive meristems that can withstand below-freezing temperatures. This process, called hardening off, is triggered by short days and lower temperatures (Weiser, 1970). Complete endodormancy in deciduous trees is typically attained by November or December and brief warm periods will not influence growth once trees are hardened off (Larcher, 2005).

Short days and cold temperatures induce production of the plant hormone ABA. ABA influences gene expression of stress proteins synthesis and is associated with regulating dormancy processes (Powell, 1987; Somerville, 1996). ABA levels in dormant seeds have been extensively studied (Goldwin, 1992), but less is known about the interaction between ABA and deciduous tree buds.

In order to overcome dormancy, ABA concentrations must be sufficiently degraded to allow for gibberellin (GA) to promote flowering and growth. Davison and Young, (1973) found that ABA levels in peach in autumn were tenfold the amount found during the summer season, and decreased with bud swell, showing a relationship between decreasing ABA levels and breaking dormancy (Davison \& Young, 1973). An orchard 
site's elevation and climate must be matched accordingly with a variety's chilling requirements to ensure successful bloom timing in the spring.

Most temperate and subtropical perennial plant species require exposure to cold temperatures for their normal development during the dormancy period. Growers must understand the relationship between a variety, its necessary chilling requirement and the orchard's climate for successful production. If winter temperatures do not satisfy a variety's chilling requirement, trees will show signs of delayed bloom and foliation, reduced fruit set and buttoning (flowers which show external signs of successful pollination set but never develop into fruit) and decreased fruit quality (Byrne \& Bacon, 1992).

Chilling Accumulation Models. To measure effective chilling temperatures during tree dormancy, several chilling accumulation models and corresponding chilling temperature values have been proposed for growers over the last sixty years. The three most widely used models are the Chilling Hours Model (Weinberger, 1950), the Utah Chilling Unit Model ( Richardson, et al., 1974), and the Dynamic Model (Fishman, et al., 1987a ).

Chilling Hours $(\mathrm{CH})$ are the simplest way to measure chilling. $\mathrm{CH}$ are measured as the accumulated amount of hours with temperatures $45^{\circ} \mathrm{F}$ or lower during an industry designated time period (typically November $1^{\text {st }}$-March 30) (Glozer \& Grant, 2005; Weinberger, 1950). Various $\mathrm{CH}$ requirements have been proposed for deciduous tree crops. Prunus species are estimated to require between 50 and $1700 \mathrm{CH}$ (Sedgley \& Griffin, 1989, p. 17) while the almond variety Nonpareil has been observed to require $400 \mathrm{CH}$ for rest completion (Weinberger, 1950). 
Issues with the chilling hour model occur when temperatures below $45^{\circ} \mathrm{F}$ alternate with temperatures above $45^{\circ} \mathrm{F}$, resulting in a cancelling effect that is unaccounted for in the chilling hour model (Glozer \& Grant, 2005). This cancelling effect commonly occurs in key almond growing Mediterranean climates. More complex models have been proposed to better measure chilling temperatures.

The Utah Chilling model measures chill accumulation from $36.5^{\circ} \mathrm{F}$ to $54.5^{\circ} \mathrm{F}$ in the form of Chilling Units (CU) (Byrne \& Bacon, 1992; Richardson, et al., 1974). Within this range are several sub-ranges with weighted CU values (Table 2.) (Richardson, 1974). Table 2. Temperature ranges and their corresponding values in weighted Utah Chill Units using the Utah Model (Byrne \& Bacon, 1992).

\begin{tabular}{|l|}
\hline Chill Unit Weights \\
\hline 1 hour below $34 \mathrm{~F}=0.0$ chill unit \\
1 hour $34.01-36 \mathrm{~F}=0.5$ chill unit \\
1 hour $36.01-48 \mathrm{~F}=1.0$ chill unit \\
1 hour $48.01-54 \mathrm{~F}=0.5$ chill unit \\
1 hour $54.01-60 \mathrm{~F}=0.0$ chill unit \\
1 hour $60.01-65 \mathrm{~F}=-0.5$ chill unit \\
1 hour $>65.01 \mathrm{~F}=-1.0$ chill unit \\
\hline
\end{tabular}

Temperatures outside of this range are zero or negatively accumulated. This model works well in cool and cold temperate climates but problematically results in excessive accumulations of negative chill values in sub-tropical climates (Luedeling, Zhang, Leudeling \& Givetz, 2009). The Positive Utah Chilling model is a modification of the Utah model where the negative values are omitted. This model's application in sub-tropical climates has improved upon the Utah's results (Linsley-Noakes, Lou \& Allan, 1995; Richardson, et al., 1974).

The Dynamic Model (Erez, et al., 1988; Fishman, et al., 1987a ) was developed in Israel and is more widely accepted for warm temperate and sub-tropical climates 
(Luedeling, et al., 2009). This model involves a complex function allowing for chill measurements to be reversed by high temperatures until they reach a certain threshold accumulation. Once duration and intensity of chilling reaches its threshold accumulation, or Chilling Portion, the model begins accumulating chilling in an irreversible manner. The model also includes a cancelling effect for temperatures alternating above and below $45^{\circ} \mathrm{F}$.

The chilling hours and Utah Chilling models are widely accepted as industry standards for chilling measurement amongst both annual and perennial crops. The Dynamic model, although formulated around the same time as the Utah Chilling model in the 1970s, is less well known amongst industry leaders and is presented by the UC Davis Fruit and Nut Center website as a research tool rather than an industry standard model.

Growing Degrees. Growing Degrees $\left(\mathrm{GD}^{\circ}\right)$ refer to accumulated warm temperatures that are required for an organism's physiological development (Wilson \& Barnett, 1983). Research shows that growth and development speed up with increasing temperature and slow under cooler temperatures (Zalom, et al., 1983). Cesaraccio et al. (2001) states that 'the accumulation of heat over time is called 'physiological time,' and growing degrees are a more accurate measure of development than physical time" (Cesaraccio, Spano, Duce \& Snyder, 2001).

Growing Degrees can be expressed as growing degree hours $\left(\mathrm{GDH}^{\circ}\right)$ when hourly data is available, or averaged as growing degree days $\left(\mathrm{GDD}^{\circ}\right)$ when only daily minimum and maximum temperatures are available.

Historically, $\mathrm{GDD}^{\circ}$ have been used to estimate entomological reproductive cycles in order to anticipate when to spray crops. They have also been extensively researched 
on annual cropping systems (Idso, Jackson, Pinter, Reginato \& Hatfield, 1981; Russelle, Olson, Wilhelm \& Power, 1984). Research from 1969 until the advent of advanced microprocessing systems relied on averaged daily maximum and minimum temperatures fitted to sine, double sine, rectangular or triangulated functions representing daily diurnal fluctuations (Baskerville \& Emin., 1969; Cesaraccio, et al. 2001; Zalom, et al., 1983). Most historical weather data only reports daily minimum and maximal temperatures.

The simplest $\mathrm{GDD}^{\circ}$ model calculates the average daily maximum and minimum temperatures and subtracts them from the base temperature (Equation 1) (usually 41$50^{\circ} \mathrm{F}$ or $\left.5-10^{\circ} \mathrm{C}\right)$ (Zalom, et al., 1983).

$\mathrm{GDD}^{\circ}=\left[\left(\mathrm{T}_{\mathrm{MAX}}-\mathrm{T}_{\mathrm{MIN}}\right) / 2\right]-\mathrm{T}_{\mathrm{BASE}}$ (Equation 1)

Similar to issues with chilling, Roltsch et al (1999) expresses that due to the site, species and even variety-specific nature of physiological processes, errors are common when using averaged GDD developmental rates and thresholds (Roltsch, Zalom, Stawn., Strand \& Pitcairn, 1999). Ruml (1999) acknowledges that base temperatures vary across environments and also across modeling methods (Ruml, Vukovic \& Milatovic, 2010; Snyder, Spano, Cesaraccio \& Duce, 1999).

$\mathrm{GDH}^{\circ}$ are the most accurate way of measuring true heat accumulation (Roltsch, et al., 1999; Ruml, et al., 2010) and are defined as one degree above a base threshold temperature $\left(\mathrm{T}_{\mathrm{BASE}}\right)$ for one hour (Equation 2$)$. When the base temperature is below the hourly minimum temperature $\left(\mathrm{T}_{\mathrm{HOUR}}\right)$, the base temperature is subtracted from the minimum temperature to determine $\mathrm{GDH}^{\circ}$ accumulation. When the base temperature is above the maximum hourly reading, no $\mathrm{GDH}^{\circ}$ are accumulated (Snyder, 1985). $\mathrm{GDH}=\left(\mathrm{T}_{\mathrm{HOUR}}-\mathrm{T}_{\mathrm{BASE}}\right)$ (Equation 2) 
Roltsch et al. (1999) compared seven GDD ${ }^{\circ}$ models with $\mathrm{GDH}^{\circ}$ summation and found that more complicated models (sine wave, rectangular averaging models) were less accurate than the simple hourly accumulation model. The authors also found that model results were more consistent during warm seasons than during winter months (Roltsch, et al., 1999). They suggest using the single triangulation or sine wave model to calculate $\mathrm{GDD}^{\circ}$ if hourly data are not available.

\begin{abstract}
Almond Bloom
Almonds are one of the earliest deciduous fruit trees to bloom in late winter and early spring (Vargas \& Romero, 2001). Newly formed flower buds are commonly exposed to freezing temperatures and incremental changes in temperature can mean the difference between survival and heavy crop loss for growers. Irregular frost events are more likely to permanently damage bearing surfaces than consistently cold temperatures during bloom.
\end{abstract}

Bloom is defined as the period in the almond tree in which the flowers enter "popcorn stage" where petals have emerged from sepals. Initiation of almond bloom can change from year to year and be affected by location. Varietal sequence of bloom will rarely change but bloom overlap between adjacent varieties varies by year and location (Vargas \& Romero, 2001).

\title{
Annual Reproductive Cycle
}

Almond trees are alternate bearing, meaning that their bearing varies from one year to the next. This is because a tree's crop yield is determined by the previous two years of growth and development cycles (Janick \& Paull, 2008, pp. 711-713). These include growth and dormancy patterns, changes from vegetative growth to initiation of 
reproductive buds, flowering, and nut growth and development (Sedgley \& Griffin, 1989). Different varieties have characteristic bearing habits. These habits are determined by the developmental relationship between terminal and lateral shoots (Kester, et al., 1996).

Almond flower buds grow laterally on spurs or lateral shoots for 4-6 years (Rieger, 2006). Flower bud differentiation for the following year's bloom occurs on shoots and spurs from July to August, and the floral development period ranges from October to December (Janick \& Paull, 2008, pp. 711-713; Kester, et al., 1996). The following spring, flower buds complete development and bloom (Sedgley \& Griffin, 1989, pp. 18-19). After fruit removal at harvest, the nut stem, or 'peduncle,' remains attached to the spur at the end of the cycle. Every year a new cycle begins with flower bud initiation in July (Janick \& Paull, 2008, pp. 711-713; Kester \& Gradziel, 1996)

Flower Development. Almonds are similar to other Prunus species in their morphological flower bud differentiation process. Flowers are perigynous and are formed in three phases (Polito, Micke \& Kester, 1996) that result in increased susceptibility of the pistil to freezing temperatures, resulting in the fact that the almond fruit is most vulnerable the earliest developing stages (Proebsting, 1963; Proebsting \& Mills, 1961; Proebsting \& Mills, 1978; Sedgley \& Griffin, 1989, p. 18).

First, during the induction phase, flower initiation is marked by changes in the size and shape of the shoot apical meristem. Research states that this stage most likely occurs around mid-August, but bud development timing varies across a single tree, as well as across varieties and locations (Sedgley \& Griffin, 1989, p. 19). Lamp et al. (2001) states that Nonpareil differs from other varieties in that a large portion of its floral 
differentiation occurs postharvest (Lamp, Connell, Duncan, Viveros \& Polito, 2001). This would mean that flowering in Nonpareil is more influenced by postharvest stresses occurring during the prior season than other varieties.

In the second stage, the vegetative apical and lateral meristems transition into flower primordia. This transition occurs through hormonally induced organogenetic activity that causes the apical meristem to stop bud-scale production and start forming sequential bracts on the periphery of the meristem (Kester, et al., 1996). The apical meristem then transitions to a terminal floral meristem with no further developmental activity in the bract axils. Research states that the flower bud initiation sequence is not yet fixed at this stage (Kester \& Gradziel, 1996; Sedgley \& Griffin, 1989, p. 20).

During the third stage, morphological and anatomical changes occur in the flower primordia and are observable by September. The third stage consists of gradual growth and development of different parts of the flower; sequences in this order: sepals, petals, stamens and ovaries (Kester \& Gradziel, 1996; Kester \& Ross, 1996).

Andrews et al. (1986) suggests that this third stage of flower bud and early fruit growth and development undergo four periods of low temperature development during spring de-acclimation: a dormant period during the lowest temperatures in winter with buds undergoing "deep supercooling," a transition period with bud swelling as chilling is gradually overcome, a third frost-tolerant period before bud emergence and a frostsensitive period where young flowers and fruit are at their highest susceptibility to frost (Andrews, Proebsting \& Gross, 1986; Rodrigo, 2000; Sedgley \& Griffin, 1989, p. 20). Viti and Monteleone (1991) suggested that extreme variations in winter temperatures during bud development could be the cause of flower bud anomalies in apricot. They 
cited several studies indicating that temperature variation upsets tree physiological equilibrium and causes competition among buds, resulting in browning or malformation of stamens and pistils (Brown, 1960; Legave, 1978; Viti \& Monteleone, 1991).

Prior to pollination and fertilization, flower buds utilize carbohydrate stores to develop into fully formed flowers. Floral buds overcome endormancy more quickly and are more sensitive to warming temperatures than vegetative buds. Flowers bloom before vegetative bud break (Faust, 1989b). Once buds have visibly emerged on the tree, bloom progresses through five stages: green tip (separation of bud scales, protrusion and expansion of sepals), pink bud (initial protrusion of petals), popcorn (expanding and rounding of petals), full bloom (presentation of anthers and stigma) and petal fall (abscission of petals) (Appendix C) (Austin, Hewett, Noiton \& Plummer, 1998). The pattern of blossom opening in an almond tree or branch is a sigmoid response curve where buds slowly break, then rapidly reach full bloom and then slowly progress to petal fall (IPM-ManualGroup, 1985).

Almond flowers are fragrant with five light pink or white petals and vary in size, petal shape, number of stamens, arrangement and length of anthers. Flowers typically have 30-33 stamens and one to two pistils (more than one pistil commonly results in double kernels in several varieties) (Janick \& Paull, 2008, pp. 711-712).

Anthesis refers to the period just before flowering or during flowering when a flower is fully open (Polito, et al., 1996). Pimenta and Vito (1982) observed that unlike other Prunus species, the embryo sac remains undifferentiated until anthesis in almonds (Pimenta \& Polito, 1982). This lack of embryonic development is closely related to self incompatibility and irregularities in fruit set (Polito, et al., 1996). 


\section{Bloom Timing}

Original studies on physiological dormancy and bloom timing in annual and perennial species have proposed a hormone regulated mechanism (involving several combinations between ABA, auxin, cytokinin, GA and ethylene) that drives progression from one stage to the next (Anderson, Chao \& Horvath, 2001; Nooden \& Weber, 1978, pp. 221-226; Suttle \& Hulstrand, 1994). More recent research shows a more complex relationship involving temperature thresholds, drought induced stress and PGRs, that combine to stimulate vegetative and reproductive bud primordia dormancy or growth (Anderson, et al., 1986; Rinne, Tuominen \& Junttila, 1993). Bonhomme found that dormant peach buds exposed to long and short day warm temperatures continued in their endodormant state and proposed that reproductive buds have the potential to stabilize at a state between endodormancy and ecodormancy without losing growth potential (Bonhomme et al., 1999).

The three factors that determine flowering date are amount of chilling (chilling unit requirement), amount of exposure to warm temperatures in spring before bloom $\left(\mathrm{GDH}^{\circ}\right)$, and the genetically determined threshold temperatures required to initiate growth following rest completion (Kester, et al., 1996; Weinbaum, Parfitt \& Polito, 1984). The degree to which each of these factors affects bloom response and timing varies by variety. According to Vargas and Romero (2001), bloom timing may vary by year according to the weather before and during bloom (Vargas \& Romero, 2001)

Flowering time is inherited quantitatively and seems to be caused by a single main gene and several modifier genes (Kester \& Gradziel, 1996; Socias i Company, 1997). Attempts to breed the late blooming characteristic into early blooming varieties 
have only been successful between crosses of mid-late to very late blooming varieties (Vargas \& Romero, 2001).

Occasionally growers will observe a "pre-bloom bloom" with early varieties that appears in mid- to late January. This is commonly observed in Nonpareil, where growers will observe that tree buds will swell and appear that they are going to bloom, only to remain dormant for around nine weeks before they actually open. The timing of this “pre-bloom” also varies with location (Tabuenca, 1972).

California's Central Valley accumulates Tule fog from the Sacramento Valley to the Southern San Joaquin Valley. This fog is associated with colder temperatures along the valley floor, and is thought to contribute to a later almond bloom. Butte County is above the Tule fog range and is frequently warmer than Kern and San Joaquin Counties, resulting in an earlier bloom (Connell, 2011; Kester, et al., 1996).

Bloom coincidence and the order of bloom timing between varieties are essential for determining a successful crop. The earliest blooming varieties are more subject to frost damage and unpredictable pollination weather and thus growers must relate the varieties they plant to their specific climate conditions in early spring. As the spring season progresses, the risk of frost damage decreases and temperatures are more favorable to pollination and fruit set, later blooming varieties are desirable (Kester, et al., 1977). Successful bloom overlap between varieties increases the overlap of receptive flowers and bee attraction across varieties, increasing cross pollination and fruit set.

Order of bloom timing between varieties is also important to ensure that the main producing variety is effectively pollinated. For example, if Nonpareil is the main variety, overlap with early Nonpareil bloom is particularly important because the earlier bloom of 
a variety has a higher-percentage set than does the later bloom. For this reason, Ne Plus Ultra's bloom, which reaches full bloom 6 days earlier than Nonpareil is a better pollinizer for Nonpareil than Mission, which is 5 to 7 days later than Nonpareil (Sedgley \& Griffin, 1989).

Chilling Requirements for Almonds. Almonds have a relatively low chilling requirement compared with other deciduous tree species and are quick to react to warming temperatures in spring (Kester \& Gradziel, 1996). A study on peach determined that cultivar type most greatly determines the degree of tree sensitivity to high temperature stresses during the pre-blooming, blooming and fructification stages (Citadin, Raseira, Herter \& Silva, 2001).The almond is closely related to the apricot in its chilling requirements (Perez \& Pollack, 2005). Richardson et al. (1974) and Ashcroft et al. (1977) studied chilling in peaches and determined that flowering requires two stages; the first in which the bud accumulates exposure to low temperatures (chilling) up to a threshold accumulation and the second in which the flower develops at a rate influenced by temperature (Ashcroft et al., 1977; Richardson, et al., 1974).

Research suggests that the most effective range of temperatures needed to overcome dormancy in almonds is from $40^{\circ} \mathrm{F}$ to $50^{\circ} \mathrm{F}$ and the standard industry model uses accumulated hours below $45^{\circ} \mathrm{F}$ (Alonso, Espiau, Anson \& Company, 2003; Anderson, et al., 1986). Early studies on almonds and chilling accumulation resulted in requirements from 200 to 500 hours below $45^{\circ} \mathrm{F}$, but this requirement varies by variety (Alonso, et al., 2003; Kester, et al., 1977; Rattigan \& Hill, 1986). Rattigan and Hill (1987) claim that Nonpareil requires 340 CU while Mission requires $350 \mathrm{CU}$ (Rattigan \& Hill, 1987). Contrastingly, D.E. Kester found that 
Nonpareil's chilling requirement is estimated to be around 400 chilling units while Mission (Texas) is thought to be around 100 units more (around 500) (Weinbaum, et al., 1984).

Experimentation found that buds reached higher phenological stages more rapidly in shoots exposed to higher field temperatures, although this result was not duplicated under climatic chamber conditions (Nieddu, Giunta \& Mulas, 1990).

Blooming of any cultivar takes place after its chill and heat requirements have been met. The date of blooming depends on whether the chill and heat requirement is met during the ecodormancy or endodormancy developmental stage. The chill and heat requirements of many almond varieties are still unknown.

Although chilling measurement differs amongst researchers and growers alike, the importance of chilling is increasing as climate change progresses. As growers and researchers look to expand production acreage they must understand varietal chilling requirements in new climates and locations to ensure successful production. Various upper and lower temperature thresholds for reproductive bud growth and development have been proposed. These temperatures include a range of upper threshold temperatures between $41^{\circ}$ and $50^{\circ} \mathrm{F}\left(5-10^{\circ} \mathrm{C}\right)$ (Sedgley \& Griffin, 1989). Bonhomme found that floral peach buds rapidly accumulated four times more volume at temperatures $50-64.4^{\circ} \mathrm{F}\left(10-18^{\circ} \mathrm{C}\right)$, compared with temperatures above $68^{\circ} \mathrm{F}\left(20^{\circ} \mathrm{C}\right)$ (Bonhomme, et al., 1999).

The study on peach floral buds concluded that temperature, and not photoperiod, highly influenced endormancy break (Bonhomme, et al., 1999). Studies have found that high temperatures in the period just before bloom and during bloom influenced dormancy 
break and bloom timing (Nava, Dalmago, Bergamachsi, Paniz, Pires dos Santos, \& Marodin, 2009) and caused early flowering and increased spring frost susceptibility (Sedgley \& Griffin, 1989).

Several European studies have attempted to assess the chilling and heat requirements for Spanish cultivars, but many requirements remain to be studied in California. Cultivars with very similar chilling requirements do not necessarily denote similar heat requirements. Alonso and Socias I Company (2009) concluded that bloom timing is more related to heat requirements than chilling and the late blooming genotypes have the highest heat requirements (Alonso \& Socias i Company, 2009).

Conversely, Egea et al. (2003) had the opposite conclusion, citing that flowering time in almonds has less to do with heat requirements and more to the chilling requirements of different genotypes (Egea, Ortega, Martinez-Gomez \& Dicenta, 2003). Unlike Alonso and Socias (2009), Egea et al. used varieties with a wide range of chilling requirements and very similar heat requirements.

Research on chilling and its accumulation involves several controversies and conflicting research studies. One of these is the effect of chilling negation over upper temperature thresholds. The Utah model poorly measures this effect while the chilling hour model does not include a measurement for this effect at all (Luedeling \& Brown, 2011). Another is the fact that species and cultivars widely vary in their total chilling requirements and effective temperature ranges. Growing locations differ in climate and experimental results cannot be directly translated to other sites (Luedeling \& Brown, 2011). 
Influence of Location on Bloom Timing. Alonso and Socias (2009) observed that in very cold climates where the chill requirements are met early in the winter, the heat requirements become much more important in influencing bloom timing. This study was done in the Ebro Central Valley where chilling completion is completed in the first ten days of December on average, which is similar to the California's northern Sacramento Valley. Varieties with high heat requirements may be adapted to diverse climates and locations and retain more consistent yields than those with lower heat requirements (Alonso \& Socias i Company, 2009; Citadin, et al., 2001).

Growing Degree Requirements in Almonds. Rattigan and Hill (1986) states that 5300 to $8900 \mathrm{GDD}^{\circ}\left(220-370 \mathrm{GDD}^{\circ}\right)$ above $4.5 \mathrm{C}^{\circ}$ are needed to reach $50 \%$ bloom (Rattigan \& Hill, 1986). The Richardson (1975) study averaged the growing degree days from placement in greenhouse conditions to full bloom for the model (Richardson, Seely, Walker., Anderson \& Ashcroft, 1975). This model was only based on two trees. The study then evaluated the model in the field by comparing the observed and calculated dates of full bloom. Seven orchards of Elberta peaches evaluated for phenological development according to the model's forecast and predictions were within 3.3 days of observed dates (Rattigan \& Hill, 1986; Richardson, et al., 1974).

Another study continued this modeling approach and calculated the date of rest completion and determined a chill unit and $\mathrm{GDH}^{\circ}$ requirement for deciduous trees. $\mathrm{GDH}^{\circ}$ were taken from the end of rest until sufficient $\mathrm{GDH}^{\circ}$ were accumulated to reach a pre-calculated stage of growth. Since specific chill requirements could not be physiologically determined, researchers estimated seven CU requirements and compared these with $\mathrm{GDH}^{\circ}$. Based on the two constants of $\mathrm{CU}$ requirement and $\mathrm{GDH}^{\circ}$ required for 
full bloom, the study hypothesized that any growth stage for peach could be successfully predicted (Ashcroft, et al., 1977).

Richardson et al. (1974) found that spring bud development in Redhaven and Elberta peaches is related to accumulated growing degree hours following rest completion. This study was followed with further study on the relationship to develop a chill unit model that estimates when each stage of bud growth and develop should begin (Richardson, et al., 1974; Richardson, et al., 1975). The GDH ${ }^{\circ}$ model used lower and upper thresholds of $40^{\circ}$ and $77^{\circ} \mathrm{F}\left(40.1^{\circ} \mathrm{F}\right.$ and $\left.77^{\circ} \mathrm{F}\right)$, respectively. Their hypothesis was that after rest completion, the temperature above some base level will result in growth and bud development. Richardson et al. used the Utah State chill model for cooler season crops to determine $40^{\circ} \mathrm{F}$ and $77^{\circ} \mathrm{F}\left(4.44-25^{\circ} \mathrm{C}\right)$ lower and upper thresholds, respectively (Richardson, et al., 1974; Richardson, et al., 1975).

Degrandi-Hoffman et al. (1996) estimated a specific base temperature for five almond cultivars and formed a model to predict the "progression," or rate of flowering, based on accumulated $\mathrm{GDH}^{\circ}$ (Degrandi-Hoffman, Thorp, Loper \& Eisikowitch, 1996). They assumed that the differences in bloom lengths across cultivars were the result of these different base temperatures and not each cultivar's chilling requirement. Their results indicated that Nonpareil and Mission had base temperatures of $35.2^{\circ} \mathrm{F}\left(1.7^{\circ} \mathrm{C}\right)$ and $48^{\circ} \mathrm{F}\left(8.9^{\circ} \mathrm{C}\right)$, respectively. The $\mathrm{GDH}^{\circ}$ for the bloom period for Nonpareil and Mission were 232 and 72, respectively. DeGrandi-Hoffman et al. (1996) state that the experiment resulted in more accurate predictions of pre-peak bloom than post-peak bloom. The age of the petals is claimed to cause the flowers to be more affected by rain or wind and therefore progress the bloom more rapidly than just by temperature alone, 
thus complicating the predictive model (Degrandi-Hoffman, Thorp, Loper \& Eisikowitch, 1996).

The relationship between bloom and heat accumulations is not clear cut. As one of the earliest trees to bloom in early spring, heat accumulations in almonds are subjected to slowly warming temperatures that often dip below the base threshold, resulting in no GDD accumulation. Ruml (2010) stated that base developmental threshold temperatures for apricot varied more for harvest date than for full bloom because of the greater range of harvest dates than full bloom dates (Ruml, et al., 2010). Sharp changes in temperatures just before and during bloom have been observed to influence flower tolerance to freezing temperatures, with warming temperatures decreasing tree flower tolerance while cooler temperatures may increase pistil survival (Proebsting \& Mills, 1978).

Egea et al. (2003) suggested that almond bloom is more compact in locations with higher CUs because the chilling requirements are overcome more quickly. Growers who plant high chill cultivars in warmer locations run the risk of their trees not satisfying CU requirements and failing to break dormancy (Egea, et al., 2003).

Increases in pre-blossom temperatures have been discovered to speed up flower bud development and thus accelerate bloom progression. In apricot, warmer temperatures $\left(6-7.6^{\circ} \mathrm{C}\right.$ above average ambient temperatures) resulted in an earlier bloom and rapid flowering over a shortened period of time, but were detrimental to final fruit yields (Rodrigo \& Herrero, 2002) . In apple, bloom length was shortened and bloom density was low under warm weather conditions (Abbott, 1962).

\section{Bee Pollination}


A colony's field bee population is diversified into pollen foragers or nectar foragers. Pollen foraging bees are the most effective pollinators because they favor newly opened flowers and contact the anthers and stigmas where pollen presentation and stigma receptivity is highest. Nectar foraging bees are not as effective because they typically visit older flowers that have lost their stigma receptivity and remain on flower petals and feed from the nectar cup without coming into contact with the pollen. Colony quality, flower age, cultivar and time of day or season are all determinate factors in the proportion of pollen to nectar foragers (Camazine, 1993; Thorp, 1996).

Beekeepers can influence the amount of bees involved in pollen foraging by installing pollen traps which reduce pollen accumulation in the hive, or by feeding bees sugar syrup during bloom to reduce the need for nectar collection. Flight activity is also related to a colony's developing brood and worker populations. Beekeepers can also increase bee density which quickly depletes food sources near to the hive and forces bees to forage over a larger area, increasing cross pollination potential (Burgett, et al., 1984; Degrandi-Hoffman, et al., 1992).

Colony Management. Colonies must be monitored throughout the year to ensure optimal bee health and pollinating potential. Colony quality and strength during almond bloom is the result of the previous year's management. Bees lost to colony collapse or pesticide poisoning during summer crop pollination are not recovered in time for successful pollination during almond bloom the next spring (Thomson \& Goodell, 2002) Colony strength is defined by frames of bees and square inches of brood. A high quality and strongly populated colony has six to eight frames of bees, active laying queen and one to two frames of brood in each colony (Burgett, et al., 1984). Strong colonies are 
especially needed at the beginning of bloom because the earliest flowers of each variety have the highest potential to set nuts. If bloom is rapid and dense, low worker populations will not be able to match the rate of opening flowers (Thorp, 1996) (Bosch, Kemp \& Peterson, 2000; Burgett, et al., 1984).

Colony Distribution. When pollinating almonds, beekeepers usually maintain two to three hives at regular intervals throughout an orchard (Figure 6) (Delaplane \& Mayer, 2000). Hives are placed in sunny locations to encourage flight activity. These locations can be throughout and around the orchard to allow for optimal bee density. Orchards on 40 acres or less can be effectively pollinated with hives placed just around the perimeter (Thorp, 1996). For larger orchards, bee colonies should be clustered at every other interval and placed inside the orchard (Degrandi-Hoffman, et al., 1992).

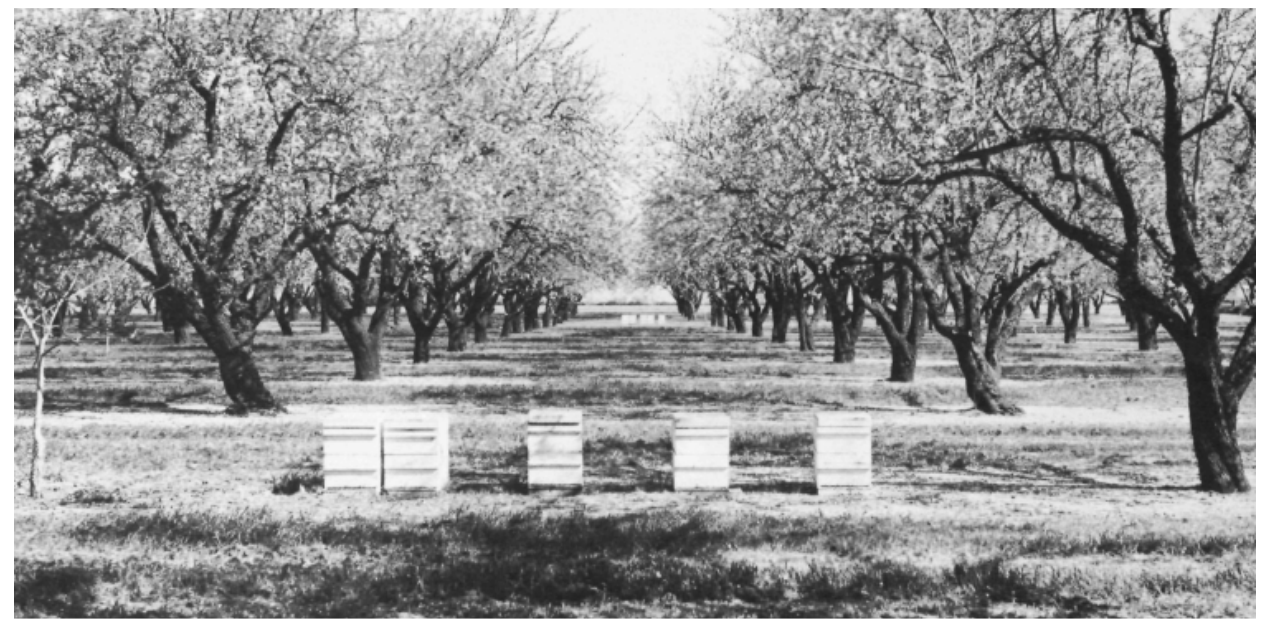

Figure 6 . Honey bee colonies are placed at $1 / 4$ acre intervals in almond orchards to promote successful cross pollination.

\section{Yield}

Final yield of a tree is determined by bloom density, pollinated blossom percentage and the amount of damaged blossoms/fruits. Many factors contribute to blossom damage, decreased fruit set and yield losses, including: the previous year's crop, 
orchard defoliation due to disease pressure or water stresses, unfavorable honey bee conditions during bloom, weather conditions in the 30 days or so following bloom, drought stress in summer and early fall and excessive moisture in root zones (Connell, 2011; Kester \& Grasselly, 1987). Temperatures before bloom, during bloom and in the period following bloom are the greatest and most unpredictable factors affecting final crop yields (Rodrigo \& Herrero, 2002).

\section{Fruit Set and the Effective Pollination Period (EPP)}

Williams (1970) defined EPP as the "period during which pollination is effective at producing fruit" (Williams, 1970). Similarly, Sanzol and Herrero (2001) state that the duration of the EPP in fruit trees is defined by stigma receptively, pollen tube kinetics and ovule longevity minus the lag between pollination and fertilization (Sanzol \& Herrero, 2001).

Yield in almonds following pollination hinges mainly upon the EPP and the number of fertilized flowers per tree, but also includes additional factors such as temperature, flower quality and chemical treatments (Connell, 2011; Degrandi-Hoffman, et al., 1996), as well as bud density and floriferous capability of different genotypes (Dicenta, Ortega, Cánovas \& Egea, 2002; Kodad \& Socias i Company, 2009). Studies on peach flower quantities (Cristoso, 2002) post-fertilization fruit drop (Goldwin, 1992) and apple cropping variability (Jackson \& Hamer, 1980) all showed that EPP was the most important factor in fruit yield.

The studies on EPP's exact timing during bloom (early in bloom, mid-bloom, or during the late stages of bloom) are contradictory. A study on EPP in almonds discovered that the cultivar Guara had maximum fruit set and stigma receptivity two days 
after pollination (Kodad \& Socias i Company, 2009). They attributed the higher fruit set in their experiment to better flower longevity at cooler temperatures during pollination.

Ortega et al. (2007) also observed respectable fruit set counts from day 0 to day 4 following emasculation (flower stamen removal in the process of artificial crosspollination) (Ortega, Dicenta \& Egea, 2007). Griggs and Iwakiri (1964) detected that Nonpareil was more receptive from day 1-4 after the onset of anthesis and had very poor fruit set when pollinated more than 5 days after anthesis(Griggs \& Iwakiri, 1964).

Just before and during the anthesis stage, flower bud development and pollen tube growth are both sensitive to extreme temperatures (Rodrigo \& Herrero, 2002; Williams, 1970) and rain or high relative humidity can be detrimental to successful pollination. Humidity also increases disease in flowers (Gradziel \& Weinbaum, 1999)

\section{Pollen Grain Germination, Pollen Tube Growth and Ovary Fertilization}

Once the pollen comes into contact with the stigma, the pollen grain must gain the necessary hydration to germinate (Shivanna \& Heslop-Harrison, 1981). Temperatures below $44.6-50^{\circ} \mathrm{F}$ cause the pollen grain and tube membrane to lose contact. Almonds have a positive membrane hydration response to low temperatures compared to peach and fertilization of the ovary occurs within a few days of successful pollination, around 3.5 days after initial growth of the pollen tube (Weinbaum, et al., 1984)

Rodrigo and Herreo (2002) observed that warmer conditions $\left(42.8-45.68^{\circ} \mathrm{F}\right.$ above ambient temperatures) decreased style length and underdeveloped pistils in apricot, resulting in slowed ovary growth. The authors concluded that pre-blossom temperatures affect fruit set and subsequent yields and that warmer temperature during flower development has a negative effect on flower viability and fruit set (Rodrigo \& Herrero, 
2002). Studies have shown clear negative relationships between warm pre-blossom temperatures and fruit set in apple (Beattie \& Folley, 1978; Jackson \& Hamer, 1980) and delays in the formation of male and female gametophytes resulting in low pollen viability in almonds (Nava, et al., 2009).

\section{Fruit and Nut Development}

Once flowers open, those that are pollinated and successfully fertilized develop into nuts. Part of the mature almond fruit can be tied to parallel structures within the flower. The base of the flower, or ovary, normally has two ovules in each flower carpel. Though most varieties produce one kernel per fruit, some varieties are prone to producing double kernelled nuts under favorable pollination conditions (Egea \& Burgos, 1995; Grasselly \& Gall, 1967).

The fruit consists of the exocarp, mesocarp (hull) and endocarp (shell). The fertilized gametes develop into the ovule which fills the ovary cavity and becomes the seed, or almond kernel (Hawker \& Buttrose, 1979; Kester, et al., 1996).

During the first stage of hull, shell and integument growth, the entire fruit remains soft and pliable. Unfertilized fruit remains on the tree for 3 weeks until an abscission layer forms and drops the empty fruit. In the fertilized fruit, cell division is complete in 3-4 weeks and cell expansion is responsible for the remainder of nut development. Cell division, growth rates and final fruit size have all been discovered to be positively correlated with warmer daily temperatures, resulting in larger fruit size under warmer temperature regimes (Corelli-Grappadelli \& Lakso, 2002).

Fruit development occurs over a two month period from late February to early May. The actual length of time required for development is inversely proportional to the 
tree's accumulated $\mathrm{GDH}^{\circ}$ during this stage (Degrandi-Hoffman, et al., 1996; Egea, et al., 2003).

An orchard will undergo three typical periods of flower and nut drop; (1) within a few days of flowering because flowers were defective and ovules did not enlarge (2) after several weeks, unpollinated flowers and fruit abscise from the tree, and (3) in April or May, larger nuts that stop growing will drop because an abscission layer develops at the nut stem (Kester \& Griggs., 1959). This last drop is thought to be a natural thinning process that the tree undergoes to avoid resource competition between nuts (Hill, Stephenson \& Taylor, 1985).

Nuts undergo the second stage hardening and embryo growth from the end of April to May, depending on location and variety. The shell portion of the nut begins to harden and growth of the developing nut can cause splits in the shell, leading to reduced quality and marketing losses. Almond varieties can be divided into hard and soft shelled varieties. Hard shelled varieties that are grown in Europe have 25-30 \% shelling and harden completely at this stage. California varieties also experience shell hardening but have a higher shelling percentage, typically $65 \%$ for Nonpareil, $45 \%$ for Mission and $35 \%$ for Peerless. At the end of the shell hardening stage, the dry weight of the seed increases (Asai, et al., 1996; Moulton, 1996).

At stage three of nut development, maturity and ripening occur. During this stage, the anatomical differentiation of the fruit (hull), nut (shell) and seed (kernel) is finished. As the nut approaches maturity, it undergoes both dehiscence and formation of an abscission layer at the nut-peduncle connection. Dehiscence (or opening, at maturity, to release its contents) involves the splitting of the hull along the suture line, and drying 
of the hull and shell. When the in-hull nut is shaken from the tree, the short peduncle remains and serves as a record of previous production (Kester, et al., 1996).

\section{Temperature and Yield}

Almond crop yields frequently suffer damage by late frosts or poor fruit set because of reduced pollination and fertilization during cold (below $45^{\circ} \mathrm{F}$ ), overcast or rainy weather(Vargas \& Romero, 2001). Almonds have shown resilience to cold weather during late winter bloom dates by demonstrating continued pollen germination and tube growth at low temperatures. Weinbaum et al. (1984) observed a small amount of pollen germination and tube elongation at $39.2^{\circ} \mathrm{F}$ (Vargas \& Romero, 2001; Weinbaum, et al., 1984).

A study conducted on the variation among Prunus species and within almond varieties in male gametophytic response (i.e., pollen germination and tube elongation) to temperature found that both 'Nonpareil' and 'Mission' had maximum pollen germination at $60.8^{\circ} \mathrm{F}$. These two varieties also had $100 \%$ tube elongation at $75.2^{\circ} \mathrm{F}$ (Weinbaum, et al., 1984). Socias i Company (1976) observed a similar threshold for 'Ne Plus Ultra' pollen tube growth in vivo (Socias i Company, Kester \& Bradley, 1976). All almond varieties studied showed declines in germination at temperatures above $82.4^{\circ} \mathrm{F}$, showing that high temperatures are more detrimental during and just after almond bloom than lower temperatures (below $4^{\circ} \mathrm{C}$ ) (Weinbaum, et al., 1984).

Although it is commonly known that temperatures during bloom significantly affect yields, a study on apples discovered that pre-blossom temperatures also greatly influences yield. In an effort to integrate meteorological variables influencing crop production Beattie and Folley (1977) conducted multiple regression analysis which 
showed that weather at flowering time had an effect on the subsequent apple fruit production, but pre-blossom temperatures also had a clear effect on yield.

These results were later confirmed showing a negative correlation between crop load and warm pre-blossom temperatures (lack of chilling) in apple (Beattie \& Folley, 1977). It was also identified that mean and maximum temperatures are the most important parameters influencing fruit set (Jackson \& Hamer, 1980, Jackson, Hamer \& Wickenden, 1983). In pear, cold temperatures have been positively correlated to yield in pear (Browning \& Miller, 1992).

Unfortunately, studies on Prunus species are contradictory. One greenhouse study on sweet cherry potted trees showed reduced fruit set under high pre-blossom temperature regimes, but another on almonds resulted in no significant change in fruit set percentages (Beppu, Okamoto, Sugiyama \& Kataoka, 1997; Egea \& Burgos, 1995). Many of these experiments have been environmentally controlled and cannot be directly compared to the behavior of mature trees under orchard conditions.

To provide information that can be directly compared to field conditions, Rodrigo and Herrero (2002) suggested a method using plastic covered trees in the orchard to evaluate temperature effects on yield as an alternative to greenhouse experimentation. They enclosed adult apricot trees in a "mobile greenhouse" structure in order to increase both the mean and maximum temperatures the tree was exposed to. Year to year variations in crop yields were found to be highly correlated early spring temperatures before and during bloom (Rodrigo \& Herrero, 2002)

A study on the effect of pre-blossom temperatures and double kernelled almonds found that increased temperatures decreased the percentage of double kernelled nuts. 
Because high ovule viability causes double kernelled nut percentages to increase, the decrease in doubles under above normal temperatures infers that flower viability is influenced by pre-blossom temperatures $\left(3-4^{\circ} \mathrm{C}\right.$ daytime increases in maximum temperatures). The authors did not find a significant effect on fruit set (Egea \& Burgos, 1995).

\section{Conclusion}

Almonds are a delicious and dynamic nut crop that has been cultivated and enjoyed by humans for centuries. Currently, California is the top producer of almonds worldwide, and the industry has successfully increased acreage and production over the past 60 years (Kester \& Ross, 1996) thanks to successful marketing, continued agricultural research and improved production methods.

Almond bloom timing, duration of bloom and final crop yield are essential elements in the industry production line from orchard to processing. These growth and developmental processes are closely related to seasonal temperature rhythms and depend on specific ranges to remain physiologically viable. Greater knowledge on the relationship between temperature change and physiological stages in almond development has the potential to extend to increased acreage and the successful vernalization of new varieties. An understanding of how almond varieties will fare under shifting climates and seasonal fluctuations will greatly benefit future growers in the industry. 


\section{CHAPTER}

\section{MATERIALS AND METHODS}

The purpose of this study was to investigate the effect of temperature on almond floral budbreak, flowering duration and final crop yields. This study focused on hourly temperatures prior to bloom and their influence on bloom timing and length, as well as temperatures during bloom and their relationship to bloom length and almond crop yields. A greater understanding of the factors affecting bloom timing and length and the relationship between bloom and nut set would allow growers to anticipate bloom dates, optimize bee activity during bloom and plan for crop yields. With this knowledge, growers may be able to select the most complementary cultivars to Nonpareil and Mission with respect to their region (Kester \& Ross, 1996).

\section{Project Descriptions}

Data for this study were taken from the University of California Cooperative Extension Regional Almond Variety Trials (RAVT) located in Butte, San Joaquin and Kern County (Lampinen, Gradziel, Yeager, Thorpe \& Micke, 2002). Funding and support for the projects were provided by the Almond Board of California, local nurseries, the staffs at California State University at Chico, San Joaquin Delta College and Paramount Farming Company.

\section{Regional Almond Variety Trials (1993-2006 RAVT)}

The RAVT experimental orchards were planted in Butte County at the CSU Chico farm, in San Joaquin County at the Delta College farm near Manteca, and in Kern County at a Paramount Farming Company orchard south of Shafter, CA. These three trials represent tree data for 32 almond cultivars, but only data from the varieties 
Nonpareil and Mission were used for this study. The orchards were planted in 1993 and came into bearing in 1996, data for this study include the years from 1996 to 2006 when the orchards were pulled out (Lampinen, et al., 2002).

The RAVT trials were simultaneously established in 1993 to evaluate 30-34 almond cultivars (depending on site). New varieties were planted in 1:1 ratios with rows of standard cultivars Nonpareil or Mission to provide effective cross pollination and data comparison. The Butte County trial was planted at 158 trees per hectare with $20-25$ trees per row and was supervised by Farm Advisor Joe Connell. The San Joaquin County trial was planted at 185 trees per hectare with 29-38 trees per row and observations were made by Farm Advisor Paul Verdegaal. The Kern County trial was planted at 213 trees per hectare on 29-38 trees per row and observations were made by Farm Advisor Mario Viveros (Lampinen, et al., 2002; Tombesi, Scalia, Connell, Lampinen \& DeJong, 2010). Trees in these trials were observed and evaluated for growth characteristics, bloom timing and progression, pest and disease susceptibility and noninfectious bud failure symptoms, as well as hull split and harvest dates, average yield, and nut quality (Lampinen, et al., 2002).

\section{Almond Bloom Project}

For this study, data on bloom dates were collected from the three RAVT trials. Observations on bloom progression were made at two to three day intervals and data were estimated as the percentage of open flowers on tree varieties across the entire row (i.e. $10 \%$ is equal to $10 \%$ of the flowers on trees across the entire being open on that date). Data included dates that trees reached $10 \%$ and $90 \%$ bloom for all three sites. The date of $90 \%$ bloom was used to define "bloom timing" because $90 \%$ bloom was the most 
consistent measurement of bloom timing across all three experimental sites. The length of bloom duration for each cultivar in the trial is represented as the number of days between $10 \%$ bloom and $90 \%$ bloom. Yield data are in pounds per tree and pest data denotes "worm damage" (including navel orangeworm (NOW), Peach Twig Borer (PTB) and Oriental Fruit Moth (OFM)) percentages affecting the final crop (Lampinen, et al., 2002).

\section{Hypotheses}

\section{Objective 1. Evaluate correlations between temperature patterns prior to bloom and}

\section{bloom timing}

Hypothesis A. A specific amount of cold temperature in the form of $\mathrm{CH}, \mathrm{CU}$ or $\mathrm{CP}$ followed by a specific amount of $\mathrm{GDH}^{\circ}$ prior to almond bloom will have a significant relationship with bloom timing for each year, variety and site

Hypothesis B. A combination of chilling and heat accumulation prior to bloom will have a greater influence on almond bloom timing than either calendar date or solely heat accumulation prior to bloom for each year, variety and site.

Hypothesis C. The date of $90 \%$ bloom will depend on an accumulated total amount of $\mathrm{GDH}^{\circ}$ from a fixed date (January $1^{\text {st }}$ ) until the actual date of $90 \%$ bloom.

\section{Objective 2: Evaluate correlations between temperature patterns during bloom and}

\section{bloom length}

Hypothesis: A greater amount of $\mathrm{GDH}^{\circ}$ during the duration of bloom will result in a significantly abbreviated bloom length for each year, variety and site. To explore the relationship between temperature conditions during bloom and the total length of bloom, the total accumulated $\mathrm{GDH}^{\circ}$ during bloom (from $10 \%$ bloom date to $90 \%$ bloom date). 


\section{Objective 3: Evaluate correlations between the length of bloom, temperature}

\section{patterns during bloom, and corresponding yields}

Hypothesis: A greater amount of $\mathrm{GDH}^{\circ}$ during the first four days of bloom will result in below average crop yields in each variety, when controlling for pest pressure, bloom length, site and year.

\section{Differences between Nonpareil and Mission}

Hypothesis: The Mission variety will have a significantly larger amount of chilling and heat accumulation requirements for bloom than Nonpareil at each year and site. Mission bloom timing will occur later than Nonpareil bloom.

\section{Experimental Design}

\section{Objective 1. Evaluate correlations between temperature patterns prior to bloom and bloom timing}

Five models were used to compare predicted $90 \%$ bloom dates with actual $90 \%$ bloom dates in Nonpareil and Mission by site and year.

Calendar Model. To explore the alternative hypothesis that bloom always occurs around the same date for each location, independent of temperature patterns (chilling and $\mathrm{GDH}^{\circ}$ ), the average date of $90 \%$ bloom for each year, site and variety was used to predict the actual date of $90 \%$ bloom. Nonpareil and Mission $90 \%$ bloom dates at the Butte, San Joaquin and Kern County sites were collected by year from the Regional Almond Variety Trial reports located online on the UC Davis Fruit and Nut Research and Information Center website. The bloom dates for Nonpareil and Mission from 1996-2006 were averaged by site and used to predict the actual date of $90 \%$ bloom by variety, year and 
site. For each predicted date, the standard error in prediction (days off the actual date of 90\% bloom) was determined.

Chilling Models. To explore the relationship between chilling accumulation and bloom timing, "Chill Date" was found using three different chilling accumulation models; the Chill Hours model (CH), the Utah Model (CU) and the Dynamic model (CP).

\section{Chill Hours Model and Chill Hour Requirements}

Chill Hours (CH) were calculated as follows:

$$
\mathrm{CH}=\sum_{i-1}^{t} T_{7.2,} \text { with } T_{7.2}= \begin{cases}0^{\circ} \mathrm{C}<T<7.2^{\circ} \mathrm{C} & : 1 \\ \text { else } & : 0\end{cases}
$$

In Mediterranean climates, temperatures typically begin to decrease around midOctober to mid-November, with the most effective chilling occurring during December and January, therefore November $1^{\text {st }}$ was the date corresponding to the start of chilling accumulation (Ruiz, Campoy \& Egea, 2008). Growers, industry leaders and agricultural research professionals traditionally use this date to start accumulating $\mathrm{CH}$ in order to monitor orchard management practices and compare the past year's weather and crop load.

The $\mathrm{CH}$ model involved calculating $\mathrm{CH}$ according to the equation above, starting on November $1^{\text {st }}$ and accumulating $\mathrm{CH}$ until the date Nonpareil and Mission reached their $\mathrm{CH}$ requirement for each site and year. The $\mathrm{CH}$ requirements used for the Nonpareil and Mission varieties were 400 and $500 \mathrm{CH}$, respectively (Table 3) (Bradley \& Maurer, 2002). The date at which Nonpareil reached $400 \mathrm{CH}$ and Mission reached $500 \mathrm{CH}$ were used as the end dates of $\mathrm{CH}$ accumulation and the dates at which to begin accumulating Growing Degree Hours $\left(\mathrm{GDH}^{\circ}\right)$. $\mathrm{GDH}^{\circ}$ accumulation is further explained in the next 
section. The average amount of $\mathrm{GDH}^{\circ}$ between the $\mathrm{CH}$ date and the date of $90 \%$ bloom at each site was then used as a threshold to predict the date of $90 \%$ bloom at a given site in a given year according to when that $\mathrm{GDH}^{\circ}$ threshold was achieved. Temperatures were taken from the CIMIS website and summed through R software according to the $\mathrm{CH}$ equation for each year, site and variety.

Table 3. Calculated chill requirements for Nonpareil and Mission in the form of Chill Hours $\left(\mathrm{CH}^{\mathrm{a}}\right)$, Chill Units $\left(\mathrm{CU}^{\mathrm{b}}\right)$ and Chill Portions $\left(\mathrm{CP}^{\mathrm{c}}\right)$

\begin{tabular}{|c|c|c|c|c|}
\hline Variety & $\mathbf{C H}$ & $\mathbf{C U}$ & $\mathbf{C P}$ & \\
\hline Nonpareil & 400 & 300 & 30 & \\
\hline Mission & 500 & 320 & 38 & \\
\hline $\begin{array}{l}{ }^{2} \text { Chill Hour Model= Pr } \\
\text { Date) and yearly averas } \\
{ }^{6} \text { Utah Chill Units (Utah } \\
35-36^{\circ} \mathrm{F}=0.5 \mathrm{CU} ; 37-48 \\
\text { average } \Sigma \mathrm{GDH}{ }^{\circ} \text { from } \\
{ }^{\circ} \text { Chill Portion (Dynam }\end{array}$ & $\begin{array}{l}\mathrm{d} \text { date of } 90 \\
\mathrm{DHH}^{\circ} \text { from } \\
\mathrm{el} \text { ) }=\text { Predi }\end{array}$ & $\begin{array}{l}\text { using the } \\
\text { until Non } \\
\text { f } 90 \% \text { bl } \\
55-60^{\circ} \circ \\
\text { ached } 90\end{array}$ & 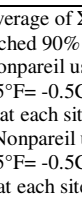 & $\begin{array}{l}\text { Number of hours } \leq 45^{\circ} \mathrm{F}\left(7.2^{\circ} \mathrm{C}\right) \text { ) from November } 1^{\text {st }} \text { until Nonpareil reached } 400 \mathrm{CH}(\mathrm{CH} \\
\text { at each site. } \\
\text { arly average } \Sigma \mathrm{CU} \text { (Number of hours corresponding to a weighted unit; } 1 \text { hour } \leq 34^{\circ} \mathrm{F}=0 \mathrm{CU} \text {; } \\
\left.\text { our }>65^{\circ} \mathrm{F}=-1 \mathrm{CU}\right) \text { from November } 1^{\text {st }} \text { until Nonpareil reached } 300 \mathrm{CU} \text { (CU Date) and yearly } \\
\text { yearly average } \Sigma \mathrm{CP} \text { (Number of hours corresponding to a weighted unit; } 1 \text { hour } \leq 34^{\circ} \mathrm{F}=0 \mathrm{CU} \text {; } \\
\left.\text { tour }>65^{\circ} \mathrm{F}=-1 \mathrm{CU}\right) \text { from November } 1^{\text {st }} \text { until Nonpareil reached } 30 \mathrm{CP}(\mathrm{CP} \text { Date) and yearly }\end{array}$ \\
\hline
\end{tabular}

\section{Utah Chill Unit Model and Utah Chill Unit Requirements}

Utah Chill Units (CU) are the summation of weighted hourly temperatures

between 34 and 64F (Richardson), beginning on November $1^{\text {st }}$ of each year. CU at time $\mathrm{T}$ (in hours) are calculated as follows:

$$
\begin{aligned}
& \mathrm{CU}=\sum_{i-1}^{t} T_{C U}, \text { with } \mathrm{T}_{\mathrm{CU}} \\
& = \begin{cases}T \leq 34^{\circ} \boldsymbol{F} & : 0.0 \\
35^{\circ} \mathrm{F}<T \leq 36^{\circ} \mathrm{F} & : 0.5 \\
37^{\circ} \mathrm{F}<T \leq 48^{\circ} \mathrm{F} & : 1.0 \\
49^{\circ} \mathrm{F}<T \leq 54^{\circ} \mathrm{F} & : 0.5 \\
55^{\circ} \mathrm{F}<T \leq 60^{\circ} \mathrm{F} & : 0.0 \\
61^{\circ} \mathrm{F}<T \leq 65^{\circ} \mathrm{F} & : 0.5 \\
T>65^{\circ} \mathrm{F} & :-1.0\end{cases}
\end{aligned}
$$

The CU model involved calculating CU according to the equation above, starting on November $1^{\text {st }}$ and accumulating CU until the date Nonpareil and Mission reached their CU requirement for each site and year. Nonpareil requires $300 \mathrm{CU}$ to break dormancy while Mission requires 320 CU (Table 3) (Alonso, et al., 2005; Kester, Raddi \& Asay, 
1973). The dates at which Nonpareil reached $300 \mathrm{CU}$ and Mission reached $320 \mathrm{CU}$ were used as the end dates of chilling accumulation using the CU model and the dates at which to begin accumulating $\mathrm{GDH}^{\circ}$. The average amount of $\mathrm{GDH}^{\circ}$ between the $\mathrm{CU}$ date and the date of $90 \%$ bloom at each site was then used as a threshold to predict the date of $90 \%$ bloom at a given site in a given year according to when that $\mathrm{GDH}^{\circ}$ threshold was achieved. Temperatures were taken from the CIMIS website and summed through $\mathrm{R}$ software according to the CU equation for each year, site and variety (Byrne \& Bacon, 1992).

\section{Dynamic Chill Portion Model and Chill Portion Requirements}

Chill Portions were calculated using the downloadable Microsoft ${ }^{\circledR}$ Excel file available through the UC Davis Fruit and Nut Center website. Hourly CIMIS weather data for from November $1^{\text {st }}$ until January $31^{\text {st }}$ were downloaded for the years 1996-2006 at following stations: Durham \#12 (Butte), Manteca \#70 (San Joaquin) and Shafter \#5 (Kern). These data were imported into the Dynamic Model Microsoft@ Excel file, which automatically calculated the Chill Portions when the Chill Portion formula was applied to new data.

The formula used for calculating Chill Portions (CP) is as follows:

$$
\begin{aligned}
& \mathrm{X}_{\mathrm{i}}=\mathrm{e} \operatorname{slp} \bullet \text { tetmlt } \frac{\mathrm{t}}{\mathrm{K}_{\mathrm{K}}} \frac{\text { - tetmlt }}{\mathrm{T}_{\mathrm{K}}} \\
& 1+\mathrm{e} \operatorname{slp} \bullet \text { tetmlt }^{\wedge} \frac{\mathrm{t}}{\mathrm{K}}_{\mathrm{T}_{\mathrm{K}}} \frac{\text { tetmlt }}{\mathrm{T}_{\mathrm{N}}} \\
& \mathrm{x}_{\mathrm{s}}=\left(\mathrm{a}_{0} / \mathrm{a}_{1}\right) \cdot \mathrm{e}^{\frac{\mathrm{e} 1-\mathrm{e} 0}{\mathrm{~T}_{\mathrm{k}}}} \\
& \mathrm{ak}_{1}=\mathrm{a}_{1} \cdot \mathrm{e}^{-\frac{\mathrm{e} 1-\mathrm{e} 0}{\mathrm{~T}_{\mathrm{k}}}} \\
& \text { inter }_{\mathrm{E}}=\mathrm{x}_{\mathrm{s}}-\left(\mathrm{x}_{\mathrm{s}}-\text { inter }_{\mathrm{s}}\right) \bullet \mathrm{e}^{-\mathrm{ak}}
\end{aligned}
$$




$$
\begin{aligned}
& t=t_{0} \quad: 0 \\
& \text { inter }_{\mathrm{s}}= \begin{cases}t>t_{0} \wedge \text { inter }_{E_{t-1}} & <1 \quad: \text { inter }_{E_{t-1}}\end{cases} \\
& t<t_{0} \wedge \text { inter }_{E_{t-1}} \geq 1 \quad: \text { inter }_{E_{t-1}} \cdot 1-x_{i} \\
& \left\{\begin{array}{cc}
t=t_{0} & : 0
\end{array}\right. \\
& \text { delt }= \begin{cases}t>t_{0} \wedge \text { inter }_{E}<1 & : 0\end{cases} \\
& t<t_{0} \wedge \text { inter }_{E} \geq 1 \quad: x_{i} \cdot \text { inter }_{E} \\
& \mathrm{CP}= \begin{cases}t-t_{0} & : \text { delt } \\
t>t_{0}<1 & : \text { delt }+C P_{t-1}\end{cases} \\
& \mathrm{e}_{0}=4.15 \mathrm{E}+03 \\
& \mathrm{e}_{1}=1.29 \mathrm{E}+04 \\
& \mathrm{a}_{0}=1.4 \mathrm{E}+05 \\
& \mathrm{a}_{1}=2.57 \mathrm{E}+18 \\
& \operatorname{slp}=1.6 \\
& \text { tetmlt }=277 \\
& \mathrm{aa}=\mathrm{a}_{0} / \mathrm{a}_{1}=5.43 \mathrm{E}-14 \\
& \mathrm{ee}=\mathrm{e}_{1}-\mathrm{e}_{0}=8.74 \mathrm{E}+03 \\
& \mathrm{t}=\text { time }
\end{aligned}
$$

The equation constants used were originated from horticultural standards used in field experimentation (Fishman, et al., 1987a ; Glozer \& Grant, 2005; Luedeling, et al., 2009).

$\mathrm{CP}$ requirements for Nonpareil and Mission varieties are currently unknown in California. $\mathrm{CP}$ requirements were calculated using an experimentally determined winter chill ratio for the California Central Valley (Luedeling \& Brown, 2011) that converted known $\mathrm{CH}$ requirements (400 $\mathrm{CH}$ for Nonpareil and $500 \mathrm{CH}$ for Mission; Table 3) to $\mathrm{CP}$. The Central Valley winter chill ratio for $\mathrm{CH}$ to $\mathrm{CP}$ is 13:1 (Luedeling \& Brown, 2011).

The $\mathrm{CP}$ model involved calculating $\mathrm{CP}$ according to the equation above, starting on November $1^{\text {st }}$ and accumulating $\mathrm{CP}$ until the date Nonpareil and Mission reached their $\mathrm{CP}$ requirement for each site and year. Using the winter chill ratio determined by Luedeling and Brown (2011), the dates at which Nonpareil reached 30CP and Mission 
reached $38 \mathrm{CP}$ were used as the end dates of chilling accumulation using the $\mathrm{CP}$ model and the dates at which to begin accumulating $\mathrm{GDH}^{\circ}$ (Table 3) (Luedeling \& Brown, 2011). The average amount of $\mathrm{GDH}^{\circ}$ between the $\mathrm{CP}$ date and the date of $90 \%$ bloom at each site was then used as a threshold to predict the date of $90 \%$ bloom at a given site in a given year according to when that $\mathrm{GDH}^{\circ}$ threshold was achieved. Temperatures were taken from the CIMIS website and summed through R software according to the $\mathrm{CP}$ equation for each year, site and variety.

\section{Growing Degree Hour $\left(\mathrm{GDH}^{\circ}\right)$ Calculation and Heat Model}

To explore the consistency of the relationship between bloom timing and calendar date, we calculated the total $\mathrm{GDH}^{\circ}$ (or heat units) via R software from January $1^{\text {st }}$ of each year until the date of $90 \%$ bloom at each site. This number was then averaged by site and used as a threshold. Yearly $\mathrm{GDH}^{\circ}$ accumulations were calculated from January $1^{\text {st }}$ until $90 \%$ bloom and bloom completion ( $90 \%$ date) to find if this gave us a more consistent $\mathrm{GDH}^{\circ}$ accumulation across years that the accumulation from the "Chill Date." January first was chosen because previous research shows that the period from late October until late December allows for sufficient chilling unit accumulation and dormancy completion in almond .

There have been very few on accurate estimations of growing degree hour $\left(\mathrm{GDH}^{\circ}\right)$ requirements in Prunus species in general, and especially in almonds (Wilson \& Barnett, 1983). For this study, hourly $\mathrm{GDH}^{\circ}$ were sourced from the CIMIS website for each year and site and calculated via R software. Temperatures outside of the $41^{\circ} \mathrm{F}$ (lower threshold) to $95^{\circ} \mathrm{F}$ (upper threshold) range were not accumulated as GDH. Temperatures within this range were subtracted from the lower threshold and summed 
over a 24 hour period to find the daily heat accumulation and labeled $\mathrm{GDH}^{\circ}$ (Tombesi, et al., 2010). These daily $\mathrm{GDH}^{\circ}$ values were then summed across time periods as appropriate for temperature pattern analysis. For the each year (1996-2006) of Nonpareil bloom dates, the sums of $\mathrm{GDH}^{\circ}$ from the date the trees reached their $\mathrm{CH}, \mathrm{CU}$ or $\mathrm{CP}$ defined chill requirements until $90 \%$ bloom were recorded as each varieties' $\mathrm{GDH}^{\circ}$ total by site and year.

The Heat Model summed the total $\mathrm{GDH}^{\circ}$ from January $1^{\text {st }}$ until the date of $90 \%$ bloom for each variety, site and year. Total $\mathrm{GDH}^{\circ}$ was averaged by site and then used to predict the date of $90 \%$ bloom for each variety. The average amount of $\mathrm{GDH}^{\circ}$ between the January $1^{\text {st }}$ until the date of $90 \%$ bloom at each site was then used as a threshold to predict the date of $90 \%$ bloom at a given site in a given year according to when that $\mathrm{GDH}^{\circ}$ threshold was achieved. Student's paired t-tests were used to find the absolute errors between the actual dates of $90 \%$ bloom and the Heat Model's prediction dates.

\section{Objective 2: Evaluate correlations between temperature patterns during bloom and}

\section{bloom length}

Bloom length (date of $10 \%$ bloom to $90 \%$ bloom date) for each year and site was calculated using CIMIS temperature readings and $\mathrm{R}$ software. $\mathrm{GDH}^{\circ}$ during bloom was correlated with the length of bloom (number of days beginning on the $10 \%$ bloom date and ending on the $90 \%$ bloom date for each year and site).

\section{Objective 3: Evaluate correlations between the length of bloom, temperature patterns during bloom, and corresponding yields}

To explore the relationship between temperature conditions during almond flower pollination and harvest yield, total $\mathrm{GDH}^{\circ}$ during bloom $\left(\mathrm{GDH}^{\circ}\right.$ accumulated from the 
date of $10 \%$ bloom to the date of $90 \%$ bloom) were correlated with yield (averaged pounds per tree) for each year and site. Length of bloom (number of days from the date of $10 \%$ bloom until the date of $90 \%$ bloom) and yield (averaged pounds per tree) were correlated as well.

\section{Weather Data}

Chilling (Chilling Units (CU), Chilling Hours (CH) and Chilling Portions (CP), Growing Degree Hours $\left(\mathrm{GDH}^{\circ}\right)$ were gathered from the CIMIS (California Irrigation Management Information System) website(http://wwwcimis.water.ca.gov/cimis/data.jsp).

CIMIS sources meteorological information from weather stations across the state. This study utilized data collected from weather stations nearest to each of the experimental orchards. Data was collected from the following CIMIS stations for each site: Durham \#12 (Butte), Manteca \#70 (San Joaquin) and Shafter \#5 (Kern). Hourly temperature data were imported into R statistical software (www.R-project.org) which was then used to calculate chilling and heat accumulations. CIMIS stations recorded air temperatures on an hourly basis.

\section{Data analysis}

Statistical analyses were conducted using R software (www.R-project.org). The student's paired t-test was used to compare models. In particular, each model (calendar, Heat, $\mathrm{CU}, \mathrm{CP}$ and $\mathrm{CH}$ ) produced a set of predicted $90 \%$ bloom dates. The paired t-test was used to assess whether the absolute prediction errors were larger for one method than for the other. The test statistic, $\mathrm{t}_{\mathrm{s}}$, was found by dividing the mean by the standard error of the mean. $\mathrm{T}_{\mathrm{s}}$ is $\mathrm{t}$-distributed with degrees of freedom equal to one less than the number of pairs $(n=33)$. P-values were found using a standard t-distribution table. Objective two 
was correlated with a scatterplot and R coefficients. Objective three was analyzed using multiple regression output. 


\section{CHAPTER}

\section{RESULTS}

The purpose of this project was to investigate three objectives: (1) correlate temperatures preceding the initiation of almond bloom with bloom timing, (2) correlate temperatures occurring throughout the duration of bloom with bloom length in days, and (3) correlate temperatures occurring during bloom with both bloom length and harvest yields.

Objective 1. Evaluate correlations between temperature patterns prior to bloom and

\section{bloom timing}

\section{Nonpareil and Mission Bloom Timing}

To evaluate the influence of temperatures prior to bloom on bloom timing (date of $90 \%$ bloom), chilling, heat accumulation and calendar models were used to predict $90 \%$ bloom for Nonpareil and Mission from the years 1996-2006 at the Butte, San Joaquin and Kern County sites. Predicted dates were compared with actual 90\% bloom dates for Nonpareil and Mission for each site and year (Figures $7 \& 8$ ).

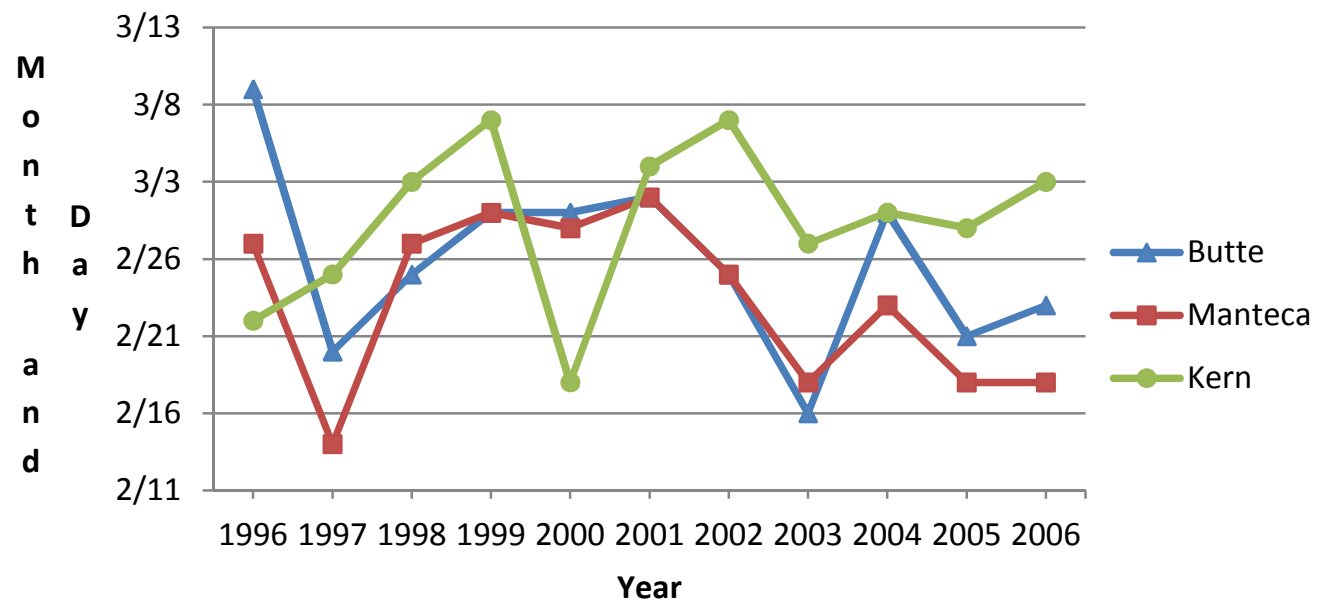

Figure 7. Observed yearly dates of $90 \%$ bloom in Nonpareil for Butte, Manteca (San Joaquin) and Kern Counties. 


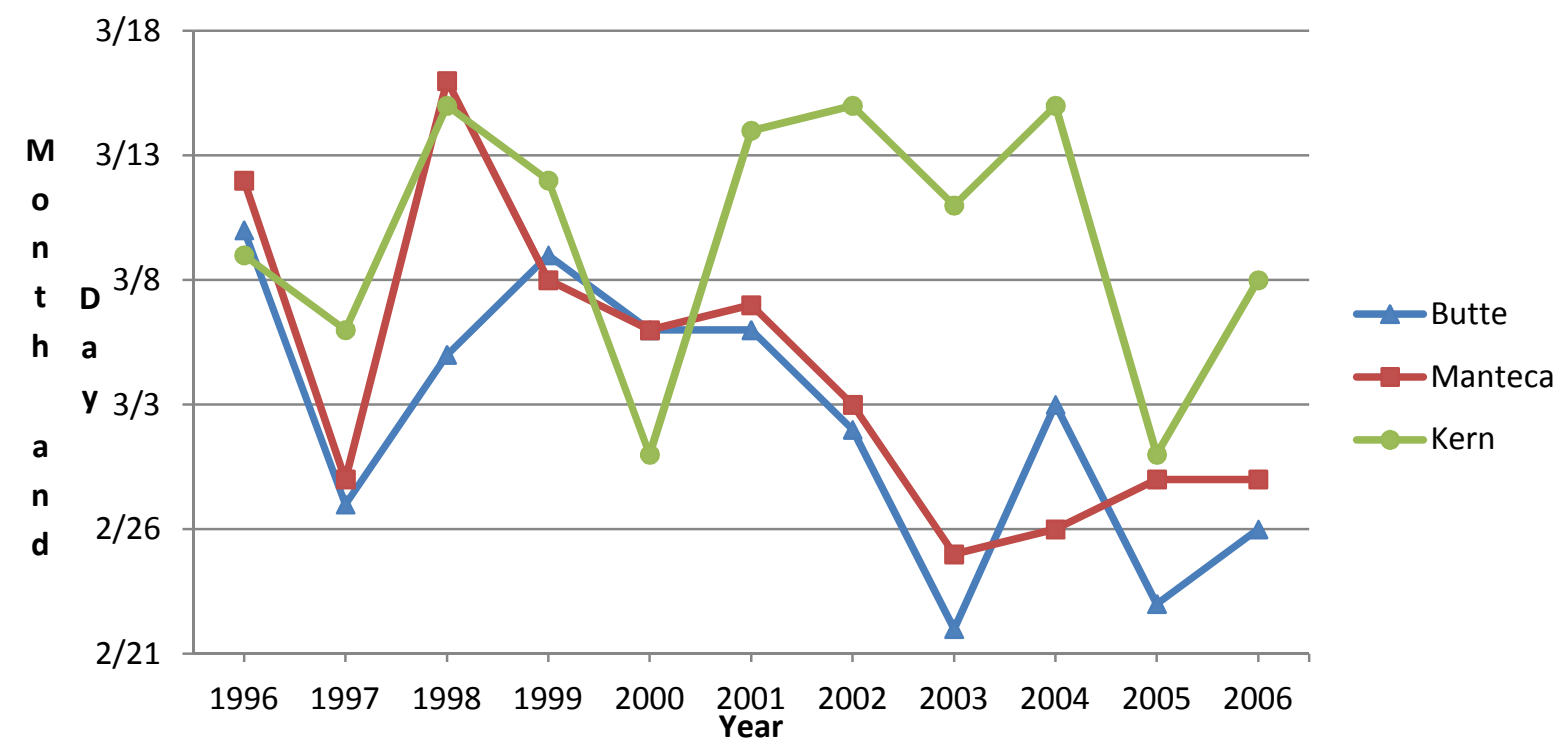

Figure 8. Observed yearly dates of $90 \%$ bloom in Mission for Butte, Manteca (San Joaquin) and Kern Counties.

Kern County $90 \%$ bloom dates were later in the spring for both varieties with an average of February $28^{\text {th }}$ for Nonpareil and March $9^{\text {th }}$ for Mission. Average Butte and San Joaquin 90\% bloom dates occurred earlier than Kern for both varieties (Table 4). Mean $90 \%$ bloom dates were very similar for Butte and San Joaquin County for both varieties, occurring within a three day span for Nonpareil and within a seven day span for Mission (Figures $7 \& 8$, Table 4).

Table 4. Mean dates of $90 \%$ bloom for Nonpareil and Mission by County

\begin{tabular}{ccccc}
\hline & Nonpareil & \multicolumn{3}{c}{ Mission } \\
\hline Site & Mean & $( \pm$ S.D. $)$ & Mean & $( \pm$ S.D. $)$ \\
\hline Butte & $25-$ Feb & \pm 5.8 & 2-Mar & \pm 5.4 \\
San Joaquin & $23-F e b$ & \pm 5.5 & 4-Mar & \pm 6.1 \\
Kern & $28-F e b$ & \pm 5.1 & 9-Mar & \pm 5.3 \\
\hline
\end{tabular}

\section{Predictive Models}

Actual bloom start date (10\% bloom) averaged 5 to 15 days before corresponding $90 \%$ bloom dates for both varieties. Average date of $90 \%$ bloom by site occurred within a three day span for Nonpareil while Mission site dates ranged over seven days. Mean 
Nonpareil 90\% bloom date occurred earliest in San Joaquin County while mean Mission $90 \%$ bloom date occurred earliest on average in Butte County (Table 4).

\section{Predictive Models versus Bloom Date in Nonpareil}

The standard errors of each model's predicted $90 \%$ bloom date in Nonpareil versus the actual date of $90 \%$ bloom were calculated by year and site and averaged (Table 5). Comparing the Calendar model to each Chilling and Heat model, the Calendar model had significantly smaller average errors in predicting the actual date of 90\% bloom in Nonpareil than the Chill Hour $(\mathrm{CH})(\mathrm{p}=0.003)$, Chill Unit $(\mathrm{CU})(\mathrm{p}=0.006)$ and Heat models $(\mathrm{p}<0.001)$. The Calendar model did not have significantly smaller average errors in predicting $90 \%$ bloom date than the Chill Portion $(\mathrm{CP})(\mathrm{p}=0.105)$ model's predictions (Table 5).

Table 5. Mean standard errors from comparing the capacity of the Calendar ${ }^{\mathrm{a}}$ Model vs. $\mathrm{CH}^{\mathrm{b}}, \mathrm{CU}^{\mathrm{c}}, \mathrm{CP}^{\mathrm{d}}$ and Heat ${ }^{\mathrm{e}}$ Models to accurately predict the date of $90 \%$ bloom in Nonpareil for the years 1996-2006 in Butte, San Joaquin and Kern Counties.

\begin{tabular}{|c|c|c|}
\hline Model & t-statistic & p-value* \\
\hline Calendar $^{\mathrm{a}}$ vs. $\mathrm{CH}^{\mathrm{b}}$ & 2.891 & 0.003 \\
\hline Calendar vs. CU ${ }^{\mathrm{c}}$ & 2.675 & 0.006 \\
\hline Calendar vs. $\mathrm{CP}^{\mathrm{d}}$ & 1.278 & 0.105 \\
\hline Calendar vs. Heat ${ }^{\mathrm{e}}$ & 4.332 & $<0.001$ \\
\hline
\end{tabular}

*Contrasts significant at $\mathrm{P}<0.05$

${ }^{a}$ Calendar Model $=$ Predicted date of $90 \%$ bloom using the average yearly date of 90\% bloom for Nonpareil from 1996-2006 at Butte, San Joaquin and Kern Co. sites

${ }^{\mathrm{b}}$ Chill Hour Model $=$ Predicted date of $90 \%$ bloom using the yearly average of $\Sigma \mathrm{CH}$ (Number of hours $\leq 45^{\circ} \mathrm{F}\left(7.2^{\circ} \mathrm{C}\right)$ ) from November $1^{\text {st }}$ until Nonpareil reached $400 \mathrm{CH}\left(\mathrm{CH}\right.$ Date) and yearly average $\Sigma \mathrm{GDH}^{\circ}$ from $\mathrm{CH}$ Date until Nonpareil reached $90 \%$ bloom at each site.

${ }^{c}$ Utah Chill Units (Utah Model) = Predicted date of $90 \%$ bloom in Nonpareil using yearly average $\Sigma$ CU (Number of hours corresponding to a weighted unit; 1 hour $\leq 34^{\circ} \mathrm{F}=0 \mathrm{CU} ; 35-36^{\circ} \mathrm{F}=0.5 \mathrm{CU} ; 37-48^{\circ} \mathrm{F}=1 \mathrm{CU} ; 49-54^{\circ} \mathrm{F}=0.5 \mathrm{CU} ; 55-60^{\circ} \mathrm{F}=0 ; 61-65^{\circ} \mathrm{F}=-0.5 \mathrm{CU} ; 1$ hour $\left.>65^{\circ} \mathrm{F}=-1 \mathrm{CU}\right)$ from November $1^{\text {st }}$ until Nonpareil reached $300 \mathrm{CU}$ (CU Date) and yearly average $\Sigma \mathrm{GDH}^{\circ}$ from CU Date until Nonpareil reached $90 \%$ bloom at each site.

${ }^{\mathrm{d}}$ Chill Portion (Dynamic Model) $=$ Predicted date of $90 \%$ bloom in Nonpareil using yearly average $\Sigma \mathrm{CP}$ (Number of hours corresponding to a weighted unit; 1 hour $\leq 34^{\circ} \mathrm{F}=0 \mathrm{CU} ; 35-36^{\circ} \mathrm{F}=0.5 \mathrm{CU} ; 37-48^{\circ} \mathrm{F}=1 \mathrm{CU} ; 49-54^{\circ} \mathrm{F}=0.5 \mathrm{CU} ; 55-60^{\circ} \mathrm{F}=0 ; 61-65^{\circ} \mathrm{F}=-0.5 \mathrm{CU} ; 1$ hour $>65^{\circ} \mathrm{F}=-1 \mathrm{CU}$ ) from November $1^{\text {st }}$ until Nonpareil reached $30 \mathrm{CP}(\mathrm{CP}$ Date $)$ and yearly average $\Sigma \mathrm{GDH}^{\circ}$ from $\mathrm{CP}$ Date until Nonpareil reached $90 \%$ bloom at each site.

${ }^{e} \mathrm{H}$ eat $=$ Predicted date of $90 \%$ bloom in Nonpareil using yearly average $\Sigma \mathrm{GDH}^{\circ}$ (Growing Degree Hours $=\Sigma\left(\mathrm{T}_{\mathrm{M}}-41.5^{\circ} \mathrm{F}\right)$ where $\mathrm{T}_{\mathrm{M}}=$ temperature $^{\circ}$ measured at a given hour in the day; and where if $\mathrm{T}_{\mathrm{M}} \geq 98.5^{\circ} \mathrm{F}\left(35^{\circ} \mathrm{C}\right)$ or $\mathrm{T}_{\mathrm{M}} \leq 41.5^{\circ} \mathrm{F}\left(5^{\circ} \mathrm{C}\right), \mathrm{GDH}^{\circ}=0$; GDH are accumulated over a 24 hour period for a daily total) from January $1^{\text {st }}$ until the date Nonpareil reached $90 \%$ bloom at each site.

The chill model results were compared separately from the Calendar and Heat models to assess which chilling model had the smallest mean errors in predicting the date of $90 \%$ bloom in Nonpareil (Table 6). The CP model had smaller average errors than the 
$\mathrm{CH}$ model. There was no significant difference in average errors between the $\mathrm{CU}$ and $\mathrm{CP}$ model results for Nonpareil ( $\mathrm{p}=0.267)$ (Table 6).

Table 6. Mean standard errors from comparing the capacity of the $\mathrm{CH}^{\mathrm{a}} \mathrm{vs.} \mathrm{CP}^{\mathrm{c}}$ and the $\mathrm{CU}^{\mathrm{b}}$ vs. CP Models to accurately predict the date of $90 \%$ bloom in Nonpareil for the years 1996-2006 in Butte, San Joaquin and Kern Counties.

\begin{tabular}{ccc}
\hline Model & t-statistic & p-value* \\
\hline CP vs. CH & 1.838 & 0.038 \\
CU vs. CP & 0.630 & 0.267 \\
\hline
\end{tabular}

*Contrasts significant at $\mathrm{P}<0.05$

${ }^{a}$ Chill Hour Model $=$ Predicted date of $90 \%$ bloom using the yearly average of $\Sigma \mathrm{CH}$ (Number of hours $\leq 45^{\circ} \mathrm{F}\left(7.2^{\circ} \mathrm{C}\right)$ ) from November $1^{\text {st }}$ until Nonpareil reached $400 \mathrm{CH}\left(\mathrm{CH}\right.$ Date) and yearly average $\Sigma \mathrm{GDH}^{\circ}$ from $\mathrm{CH}$ Date until Nonpareil reached $90 \%$ bloom at each site.

${ }^{\mathrm{b}}$ Utah Chill Units (Utah Model) $=$ Predicted date of $90 \%$ bloom in Nonpareil using yearly average $\Sigma \mathrm{CU}$ (Number of hours corresponding to a weighted unit; 1 hour $\leq 34^{\circ} \mathrm{F}=0 \mathrm{CU} ; 35-36^{\circ} \mathrm{F}=0.5 \mathrm{CU} ; 37-48^{\circ} \mathrm{F}=1 \mathrm{CU} ; 49-54^{\circ} \mathrm{F}=0.5 \mathrm{CU} ; 55-60^{\circ} \mathrm{F}=0 ; 61-65^{\circ} \mathrm{F}=-0.5 \mathrm{CU} ; 1$ hour $\left.>65^{\circ} \mathrm{F}=-1 \mathrm{CU}\right)$ from November $1^{\text {st }}$ until Nonpareil reached $300 \mathrm{CU}$ (CU Date) and yearly average $\Sigma \mathrm{GDH}^{\circ}$ from CU Date until Nonpareil reached $90 \%$ bloom at each site.

${ }^{\mathrm{c}}$ Chill Portion $($ Dynamic Model) $=$ Predicted date of $90 \%$ bloom in Nonpareil using yearly average $\Sigma \mathrm{CP}$ (Number of hours corresponding to a weighted unit; 1 hour $\leq 34^{\circ} \mathrm{F}=0 \mathrm{CU} ; 35-36^{\circ} \mathrm{F}=0.5 \mathrm{CU} ; 37-48^{\circ} \mathrm{F}=1 \mathrm{CU} ; 49-54^{\circ} \mathrm{F}=0.5 \mathrm{CU} ; 55-60^{\circ} \mathrm{F}=0 ; 61-65^{\circ} \mathrm{F}=-0.5 \mathrm{CU} ; 1$ hour $\left.>65^{\circ} \mathrm{F}=-1 \mathrm{CU}\right)$ from November $1^{\text {st }}$

until Nonpareil reached $30 \mathrm{CP}\left(\mathrm{CP}\right.$ Date) and yearly average $\Sigma \mathrm{GDH}^{\circ}$ from $\mathrm{CP}$ Date until Nonpareil reached $90 \%$ bloom at each site.

Actual dates of $90 \%$ bloom for Nonpareil in Butte, San Joaquin and Kern County

differed both in range and timing when compared to the predicted dates of $90 \%$ bloom

using the $\mathrm{CH}, \mathrm{CU}, \mathrm{CP}$, Calendar and Heat Models (Figure 9). For Butte County, the Heat

model tended to predict $90 \%$ bloom dates 2-8 days later than the other model's

predictions. The $\mathrm{CP}$ and Calendar model most closely reflected the actual bloom dates.

The $\mathrm{CH}$ and $\mathrm{CU}$ models tended to predict similar dates but over and underestimated

actual $90 \%$ bloom dates for several years in Butte County. 


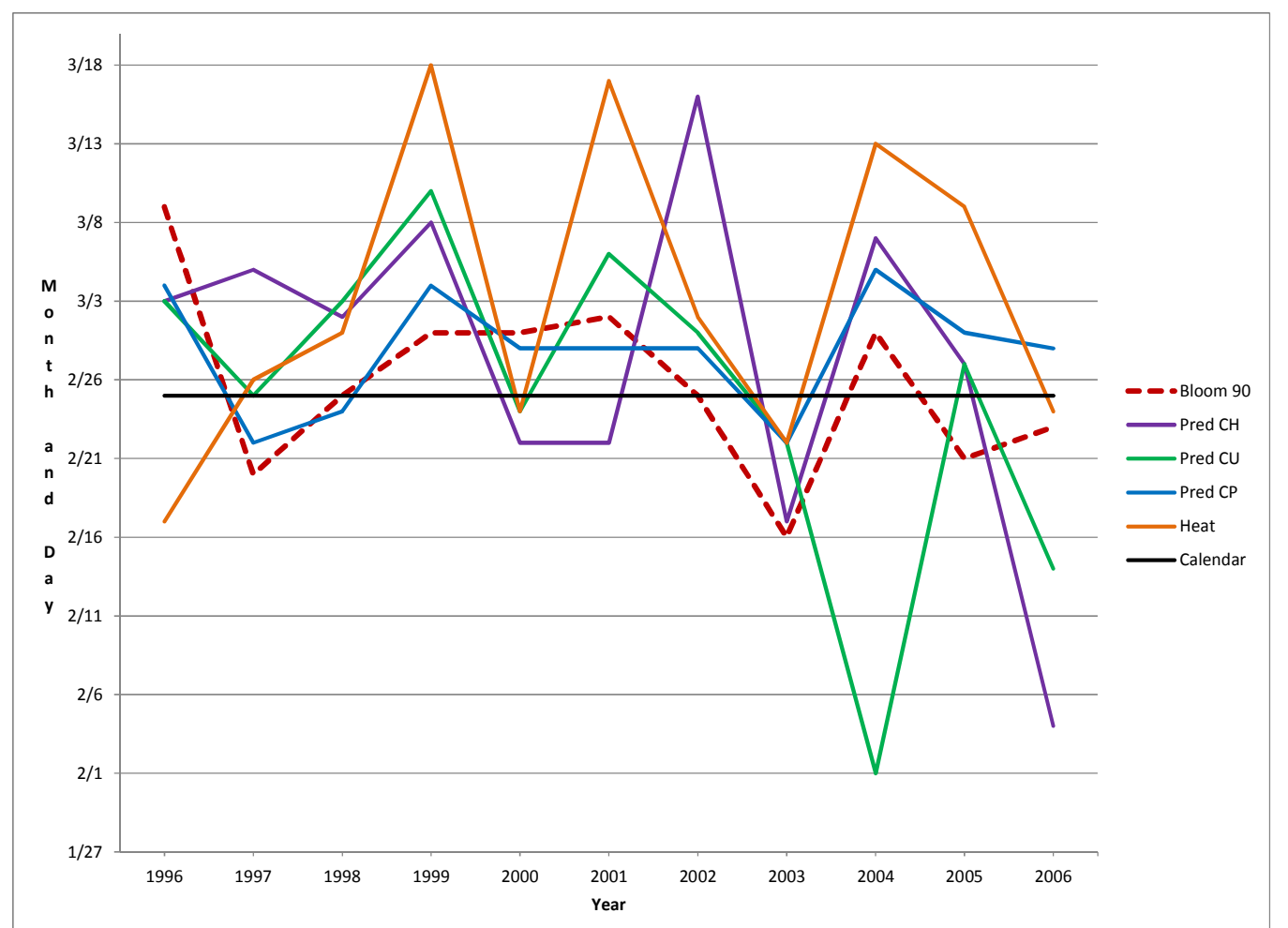

Figure 9. Butte County predicted dates of $90 \%$ Nonpareil bloom using the $\mathrm{CH}, \mathrm{CU}, \mathrm{CP}$, Calendar and Heat models compared with the actual dates of $90 \%$ bloom

${ }^{a}$ Calendar Model= Predicted date of $90 \%$ bloom using the average yearly date of 90\% bloom for Nonpareil from 1996-2006 at Butte, San Joaquin and Kern Co. sites

${ }^{b}$ Chill Hour Model $=$ Predicted date of $90 \%$ bloom using the yearly average of $\Sigma \mathrm{CH}$ (Number of hours $\left.\leq 45^{\circ} \mathrm{F}\left(7.2^{\circ} \mathrm{C}\right)\right)$ from November $1^{\text {st }}$ until Nonpareil reached $400 \mathrm{CH}\left(\mathrm{CH}\right.$ Date) and yearly average $\Sigma \mathrm{GDH}^{\circ}$ from $\mathrm{CH}$ Date until Nonpareil reached $90 \%$ bloom at each site.

${ }^{\mathrm{c}}$ Utah Chill Units (Utah Model) = Predicted date of $90 \%$ bloom in Nonpareil using yearly average $\Sigma \mathrm{CU}$ (Number of hours corresponding to a weighted unit; 1 hour $\leq 34^{\circ} \mathrm{F}=0 \mathrm{CU} ; 35-36^{\circ} \mathrm{F}=0.5 \mathrm{CU} ; 37-48^{\circ} \mathrm{F}=1 \mathrm{CU} ; 49-54^{\circ} \mathrm{F}=0.5 \mathrm{CU} ; 55-60^{\circ} \mathrm{F}=0 ; 61-65^{\circ} \mathrm{F}=-0.5 \mathrm{CU} ; 1$ hour $\left.>65^{\circ} \mathrm{F}=-1 \mathrm{CU}\right)$ from November $1^{\mathrm{st}}$ until Nonpareil reached $300 \mathrm{CU}$ (CU Date) and yearly average $\Sigma \mathrm{GDH}^{\circ}$ from CU Date until Nonpareil reached $90 \%$ bloom at each site.

${ }^{\mathrm{d}}$ Chill Portion (Dynamic Model) $=$ Predicted date of $90 \%$ bloom in Nonpareil using yearly average $\Sigma \mathrm{CP}$ (Number of hours corresponding to a weighted unit; 1 hour $\leq 34^{\circ} \mathrm{F}=0 \mathrm{CU} ; 35-36^{\circ} \mathrm{F}=0.5 \mathrm{CU} ; 37-48^{\circ} \mathrm{F}=1 \mathrm{CU} ; 49-54^{\circ} \mathrm{F}=0.5 \mathrm{CU} ; 55-60^{\circ} \mathrm{F}=0 ; 61-65^{\circ} \mathrm{F}=-0.5 \mathrm{CU} ; 1$ hour $\left.>65^{\circ} \mathrm{F}=-1 \mathrm{CU}\right)$ from November $1^{\mathrm{st}}$ until Nonpareil reached $30 \mathrm{CP}(\mathrm{CP}$ Date $)$ and yearly average $\Sigma \mathrm{GDH}^{\circ}$ from $\mathrm{CP}$ Date until Nonpareil reached $90 \%$ bloom at each site.

${ }^{e} \mathrm{Heat}=$ Predicted date of $90 \%$ bloom in Nonpareil using yearly average $\Sigma \mathrm{GDH}^{\circ}$ (Growing Degree Hours $=\Sigma\left(\mathrm{T}_{\mathrm{M}}-41.5^{\circ} \mathrm{F}\right)$ where $\mathrm{T}_{\mathrm{M}}=$ temperature measured at a given hour in the day; and where if $\mathrm{T}_{\mathrm{M}} \geq 98.5^{\circ} \mathrm{F}\left(35^{\circ} \mathrm{C}\right)$ or $\mathrm{T}_{\mathrm{M}} \leq 41.5^{\circ} \mathrm{F}\left(5^{\circ} \mathrm{C}\right), \mathrm{GDH}^{\circ}=0$; GDH are accumulated over a 24 hour period for a daily total) from January $1^{\text {st }}$ until the date Nonpareil reached $90 \%$ bloom at each site.

San Joaquin County actual 90\% bloom dates for Nonpareil tended to occur earlier

than the predictive model dates except for years 1996, 1998 and 2000 (Figure 10). The

Heat model predicted the latest bloom timing while the Chill Portion and Chill Unit

models correlated well with actual $90 \%$ bloom dates. The Calendar model correlated best with the actual $90 \%$ bloom dates in Nonpareil. Heat, CU and CP models tended to occur 3-10 days later than actual 90\% Nonpareil bloom dates in San Joaquin County. 


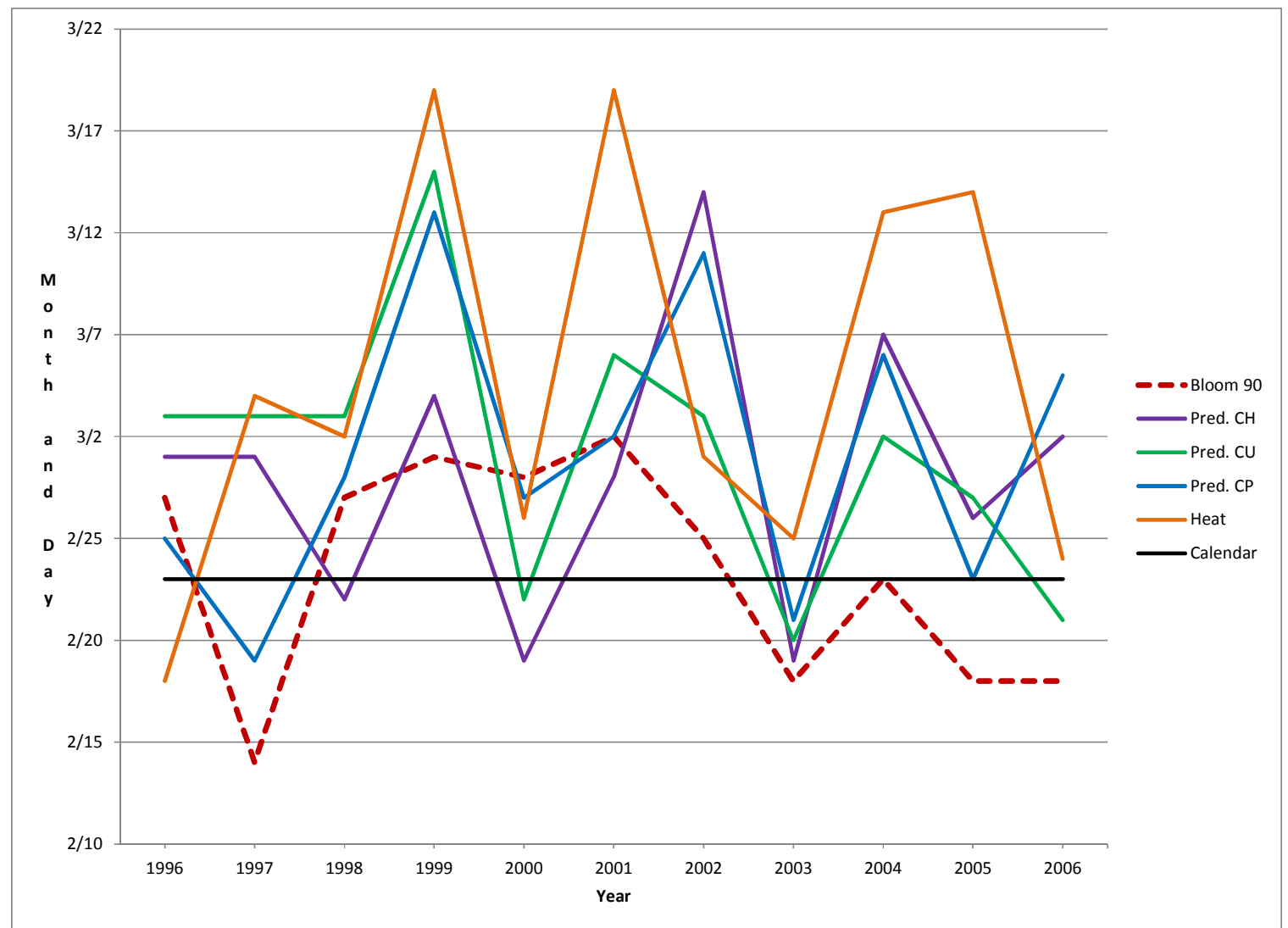

Figure 10. San Joaquin County predicted dates of $90 \%$ Nonpareil bloom using the $\mathrm{CH}$, CU, CP, Calendar and Heat models compared with the actual dates of $90 \%$ bloom

${ }^{a}$ Calendar Model $=$ Predicted date of $90 \%$ bloom using the average yearly date of 90\% bloom for Nonpareil from 1996-2006 at Butte, San Joaquin and Kern Co. sites

${ }^{\mathrm{b}} \mathrm{Chill}$ Hour Model $=$ Predicted date of $90 \%$ bloom using the yearly average of $\Sigma \mathrm{CH}$ (Number of hours $\left.\leq 45^{\circ} \mathrm{F}\left(7.2^{\circ} \mathrm{C}\right)\right)$ from November $1^{\text {st }}$ until Nonpareil reached $400 \mathrm{CH}$ (CH Date) and yearly average $\Sigma \mathrm{GDH}^{\circ}$ from $\mathrm{CH}$ Date until Nonpareil reached $90 \%$ bloom at each site.

${ }^{c}$ Utah Chill Units (Utah Model) $=$ Predicted date of $90 \%$ bloom in Nonpareil using yearly average $\Sigma$ CU (Number of hours corresponding to a weighted unit; 1 hour $\leq 34^{\circ} \mathrm{F}=0 \mathrm{CU} ; 35-36^{\circ} \mathrm{F}=0.5 \mathrm{CU} ; 37-48^{\circ} \mathrm{F}=1 \mathrm{CU} ; 49-54^{\circ} \mathrm{F}=0.5 \mathrm{CU} ; 55-60^{\circ} \mathrm{F}=0 ; 61-65^{\circ} \mathrm{F}=-0.5 \mathrm{CU} ; 1$ hour $\left.>65^{\circ} \mathrm{F}=-1 \mathrm{CU}\right)$ from November $1^{\mathrm{st}}$ until Nonpareil reached $300 \mathrm{CU}$ (CU Date) and yearly average $\Sigma \mathrm{GDH}^{\circ}$ from CU Date until Nonpareil reached $90 \%$ bloom at each site.

${ }^{\mathrm{d}}$ Chill Portion (Dynamic Model) $=$ Predicted date of $90 \%$ bloom in Nonpareil using yearly average $\Sigma$ CP (Number of hours corresponding to a weighted unit; 1 hour $\leq 34^{\circ} \mathrm{F}=0 \mathrm{CU} ; 35-36^{\circ} \mathrm{F}=0.5 \mathrm{CU} ; 37-48^{\circ} \mathrm{F}=1 \mathrm{CU} ; 49-54^{\circ} \mathrm{F}=0.5 \mathrm{CU} ; 55-60^{\circ} \mathrm{F}=0 ; 61-65^{\circ} \mathrm{F}=-0.5 \mathrm{CU} ; 1$ hour $\left.>65^{\circ} \mathrm{F}=-1 \mathrm{CU}\right)$ from November $1^{\mathrm{st}}$ until Nonpareil reached $30 \mathrm{CP}(\mathrm{CP}$ Date $)$ and yearly average $\Sigma \mathrm{GDH}^{\circ}$ from $\mathrm{CP}$ Date until Nonpareil reached $90 \%$ bloom at each site.

${ }^{e}$ Heat $=$ Predicted date of $90 \%$ bloom in Nonpareil using yearly average $\Sigma \mathrm{GDH}^{\circ}\left(\right.$ Growing Degree Hours $=\Sigma\left(\mathrm{T}_{\mathrm{M}}-41.5^{\circ} \mathrm{F}\right)$ where $\mathrm{T}_{\mathrm{M}}=$ temperature measured at a given hour in the day; and where if $\mathrm{T}_{\mathrm{M}} \geq 98.5^{\circ} \mathrm{F}\left(35^{\circ} \mathrm{C}\right)$ or $\mathrm{T}_{\mathrm{M}} \leq 41.5^{\circ} \mathrm{F}\left(5^{\circ} \mathrm{C}\right), \mathrm{GDH}^{\circ}=0$; GDH are accumulated over a 24 hour period for a daily total) from January $1^{\text {st }}$ until the date Nonpareil reached $90 \%$ bloom at each site.

The $\mathrm{CU}, \mathrm{CH}, \mathrm{CP}$ and Heat models predicted later dates than the Calendar model

for all years in Kern County. Kern County had the latest occurring actual $90 \%$ bloom dates of all three sites for Nonpareil (Figure 11). The CP and Heat predicative models tended to overestimate Kern County bloom dates by a large margin, especially in the years 1999 and 2005, while the CU model more closely reflected 90\% bloom dates, especially in 2003 and 2006. 


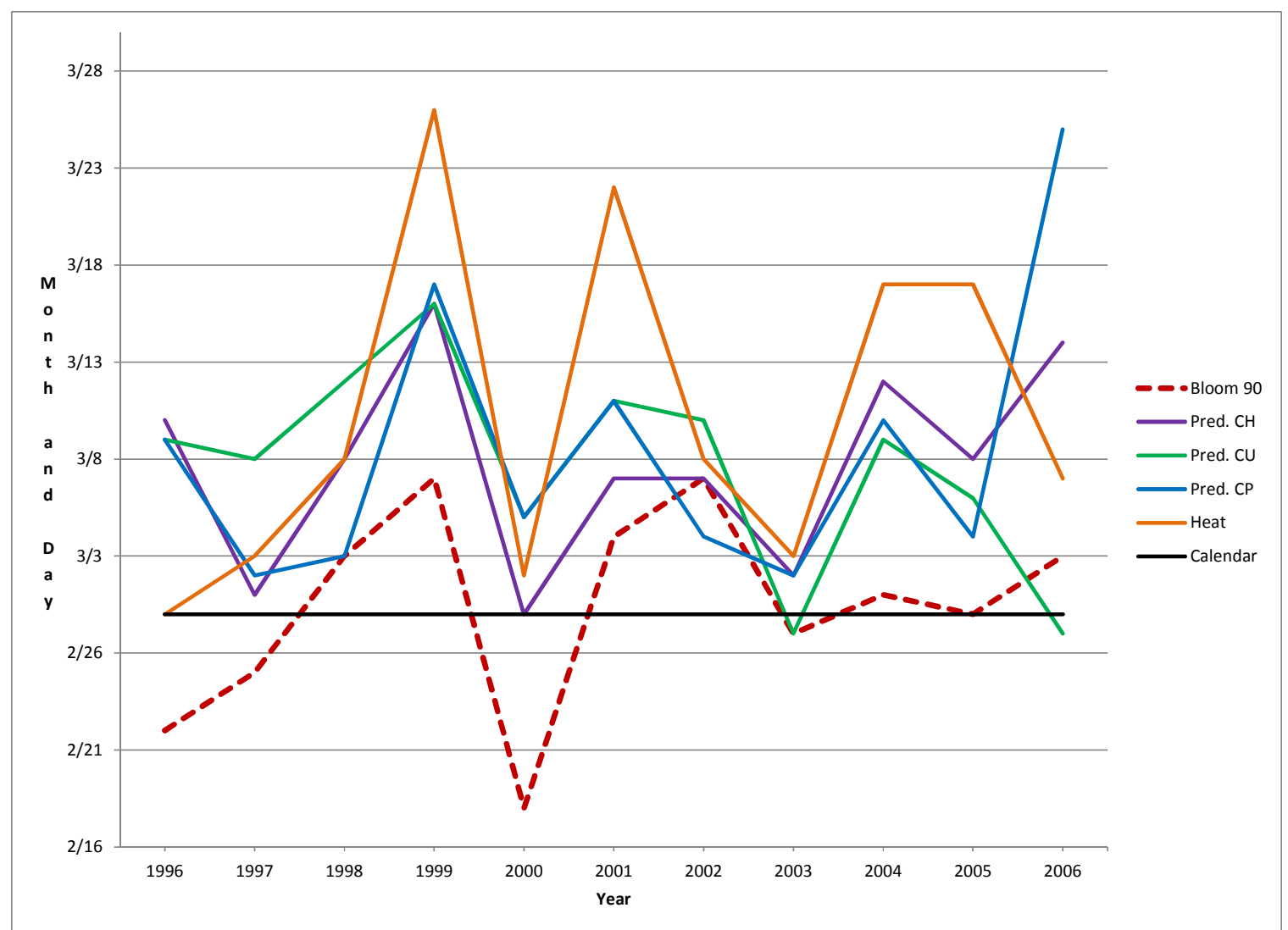

Figure 11. Kern County predicted and actual dates of $90 \%$ Nonpareil bloom using the CP, $\mathrm{CH}$ and CU Models.

${ }^{a}$ Calendar Model $=$ Predicted date of $90 \%$ bloom using the average yearly date of 90\% bloom for Nonpareil from 1996-2006 at Butte, San Joaquin and Kern Co. sites

${ }^{\mathrm{b}}$ Chill Hour Model $=$ Predicted date of $90 \%$ bloom using the yearly average of $\Sigma \mathrm{CH}$ (Number of hours $\leq 45^{\circ} \mathrm{F}\left(7.2^{\circ} \mathrm{C}\right)$ ) from November $1^{\text {st }}$ until Nonpareil reached $400 \mathrm{CH}$ (CH Date) and yearly average $\Sigma \mathrm{GDH}^{\circ}$ from $\mathrm{CH}$ Date until Nonpareil reached $90 \%$ bloom at each site.

${ }^{c}$ Utah Chill Units (Utah Model) = Predicted date of $90 \%$ bloom in Nonpareil using yearly average $\Sigma$ CU (Number of hours corresponding to a weighted unit; 1 hour $\leq 34^{\circ} \mathrm{F}=0 \mathrm{CU} ; 35-36^{\circ} \mathrm{F}=0.5 \mathrm{CU} ; 37-48^{\circ} \mathrm{F}=1 \mathrm{CU} ; 49-54^{\circ} \mathrm{F}=0.5 \mathrm{CU} ; 55-60^{\circ} \mathrm{F}=0 ; 61-65^{\circ} \mathrm{F}=-0.5 \mathrm{CU} ; 1$ hour $\left.>65^{\circ} \mathrm{F}=-1 \mathrm{CU}\right)$ from November $1^{\mathrm{st}}$ until Nonpareil reached $300 \mathrm{CU}$ (CU Date) and yearly average $\Sigma \mathrm{GDH}^{\circ}$ from CU Date until Nonpareil reached $90 \%$ bloom at each site.

${ }^{\mathrm{d}}$ Chill Portion (Dynamic Model) $=$ Predicted date of $90 \%$ bloom in Nonpareil using yearly average $\Sigma \mathrm{CP}$ (Number of hours corresponding to a weighted unit; 1 hour $\leq 34^{\circ} \mathrm{F}=0 \mathrm{CU} ; 35-36^{\circ} \mathrm{F}=0.5 \mathrm{CU} ; 37-48^{\circ} \mathrm{F}=1 \mathrm{CU} ; 49-54^{\circ} \mathrm{F}=0.5 \mathrm{CU} ; 55-60^{\circ} \mathrm{F}=0 ; 61-65^{\circ} \mathrm{F}=-0.5 \mathrm{CU} ; 1$ hour $\left.>65^{\circ} \mathrm{F}=-1 \mathrm{CU}\right)$ from November $1^{\mathrm{st}}$ until Nonpareil reached $30 \mathrm{CP}\left(\mathrm{CP}\right.$ Date) and yearly average $\Sigma \mathrm{GDH}^{\circ}$ from CP Date until Nonpareil reached $90 \%$ bloom at each site.

${ }^{e}$ Heat $=$ Predicted date of $90 \%$ bloom in Nonpareil using yearly average $\Sigma \mathrm{GDH}^{\circ}\left(\right.$ Growing Degree Hours $=\Sigma\left(\mathrm{T}_{\mathrm{M}}-41.5^{\circ} \mathrm{F}\right)$ where $\mathrm{T}_{\mathrm{M}}=$ temperature measured at a given hour in the day; and where if $\mathrm{T}_{\mathrm{M}} \geq 98.5^{\circ} \mathrm{F}\left(35^{\circ} \mathrm{C}\right)$ or $\mathrm{T}_{\mathrm{M}} \leq 41.5^{\circ} \mathrm{F}\left(5^{\circ} \mathrm{C}\right), \mathrm{GDH}^{\circ}=0$; $\mathrm{GDH}^{\circ}$ are accumulated over a 24 hour period for a daily total) from January $1^{\text {st }}$ until the date Nonpareil reached $90 \%$ bloom at each site.

\section{Predictive Models versus Bloom Date in Mission}

When comparing the Calendar model's ability to predict the date of $90 \%$ bloom in Mission to the predictions made using the four temperature models, the Calendar model was found to have smaller average errors than the $\mathrm{CH}(\mathrm{p}=0.007), \mathrm{CP}(\mathrm{p}=0.048)$ and Heat models $(\mathrm{p}<0.001)($ Table 7$)$. There was not a significant difference in average errors between the $\mathrm{CU}(\mathrm{p}=0.095)$ and the Calendar model. 
Table 7. Mean standard errors from comparing the capacity of the Calendar ${ }^{\mathrm{a}}$ Model vs. $\mathrm{CH}^{\mathrm{b}}, \mathrm{CU}^{\mathrm{c}}, \mathrm{CP}^{\mathrm{d}}$ and Heat ${ }^{\mathrm{e}}$ Models, and $\mathrm{CP}$ vs. $\mathrm{CH}, \mathrm{CP}$ Models to accurately predict the date of $90 \%$ bloom in Mission for the years 1996-2006 in Butte, San Joaquin and Kern Counties.

\begin{tabular}{lcc}
\hline \multicolumn{1}{c}{ Model } & t-statistic & p-value \\
\hline Calendar $^{\mathrm{a}}$ vs. $\mathrm{CH}^{\mathrm{b}}$ & 2.589 & 0.007 \\
Calendar vs. CU $^{\mathrm{c}}$ & 1.231 & 0.095 \\
Calendar vs. CP $^{\mathrm{d}}$ & 1.712 & 0.048 \\
Calendar vs. Heat $^{\mathrm{e}}$ & 3.648 & $<0.001$ \\
\hline
\end{tabular}

*Contrasts significant at $\mathrm{P}<0.05$

${ }^{a}$ Calendar Model= Predicted date of $90 \%$ bloom using the average yearly date of 90\% bloom for Nonpareil from 1996-2006 at Butte, San Joaquin and Kern Co. sites

${ }^{\mathrm{b}}$ Chill Hour Model $=$ Predicted date of $90 \%$ bloom using the yearly average of $\Sigma \mathrm{CH}$ (Number of hours $\leq 45^{\circ} \mathrm{F}\left(7.2^{\circ} \mathrm{C}\right)$ ) from November $1^{\text {st }}$ until Nonpareil reached $400 \mathrm{CH}\left(\mathrm{CH}\right.$ Date) and yearly average $\Sigma \mathrm{GDH}^{\circ}$ from $\mathrm{CH}$ Date until Nonpareil reached $90 \%$ bloom at each site.

${ }^{c}$ Utah Chill Units $($ Utah Model) $=$ Predicted date of $90 \%$ bloom in Nonpareil using yearly average $\Sigma$ CU (Number of hours corresponding to a weighted unit; 1 hour $\leq 34^{\circ} \mathrm{F}=0 \mathrm{CU} ; 35-36^{\circ} \mathrm{F}=0.5 \mathrm{CU} ; 37-48^{\circ} \mathrm{F}=1 \mathrm{CU} ; 49-54^{\circ} \mathrm{F}=0.5 \mathrm{CU} ; 55-60^{\circ} \mathrm{F}=0 ; 61-65^{\circ} \mathrm{F}=-0.5 \mathrm{CU} ; 1$ hour $\left.>65^{\circ} \mathrm{F}=-1 \mathrm{CU}\right)$ from November $1^{\mathrm{st}}$ until Nonpareil reached $300 \mathrm{CU}$ (CU Date) and yearly average $\Sigma \mathrm{GDH}^{\circ}$ from CU Date until Nonpareil reached $90 \%$ bloom at each site.

${ }^{\mathrm{d}}$ Chill Portion (Dynamic Model) $=$ Predicted date of $90 \%$ bloom in Nonpareil using yearly average $\Sigma \mathrm{CP}$ (Number of hours corresponding to a weighted unit; 1 hour $<34^{\circ} \mathrm{F}=0 \mathrm{CU} ; 35-36^{\circ} \mathrm{F}=0.5 \mathrm{CU} ; 37-48^{\circ} \mathrm{F}=1 \mathrm{CU} ; 49-54^{\circ} \mathrm{F}=0.5 \mathrm{CU} ; 55-60^{\circ} \mathrm{F}=0 ; 61-65^{\circ} \mathrm{F}=-0.5 \mathrm{CU} ; 1$ hour $\left.>65^{\circ} \mathrm{F}=-1 \mathrm{CU}\right)$ from November $1^{\mathrm{st}}$ until Nonpareil reached $30 \mathrm{CP}(\mathrm{CP}$ Date $)$ and yearly average $\Sigma \mathrm{GDH}^{\circ}$ from $\mathrm{CP}$ Date until Nonpareil reached $90 \%$ bloom at each site.

${ }^{\mathrm{e}} \mathrm{Heat}=$ Predicted date of $90 \%$ bloom in Nonpareil using yearly average $\Sigma \mathrm{GDH}^{\circ}$ (Growing Degree Hours $=\Sigma\left(\mathrm{T}_{\mathrm{M}}-41.5^{\circ} \mathrm{F}\right)$ where $\mathrm{T}_{\mathrm{M}}=$ temperature measured at a given hour in the day; and where if $\mathrm{T}_{\mathrm{M}} \geq 98.5^{\circ} \mathrm{F}\left(35^{\circ} \mathrm{C}\right)$ or $\mathrm{T}_{\mathrm{M}} \leq 41.5^{\circ} \mathrm{F}\left(5^{\circ} \mathrm{C}\right), \mathrm{GDH}^{\circ}=0$; $\mathrm{GDH}^{\circ}$ are accumulated over a 24 hour period for a daily total) from January $1^{\text {st }}$ until the date Nonpareil reached $90 \%$ bloom at each site.

The chill model results were compared separately from the Calendar and Heat

models to assess which chilling model had the smallest mean errors in predicting the date

of $90 \%$ bloom in Mission. There was no significant difference in average errors between

the $\mathrm{CH}$ versus $\mathrm{CP}(\mathrm{p}=0.254)$ or the $\mathrm{CU}$ versus $\mathrm{CP}(\mathrm{p}=0.474)$ models in Mission (Table 8$)$.

Table 8. Mean standard errors from comparing the capacity of the $\mathrm{CH}^{\mathrm{a}}$ vs. $\mathrm{CP}$ and the $\mathrm{CU}^{\mathrm{b}}$ vs. $\mathrm{CP}^{\mathrm{c}}$ Models to accurately predict the date of $90 \%$ bloom in Mission for the years 1996-2006 in Butte, San Joaquin and Kern Counties.

\begin{tabular}{ccc}
\hline Model & t-statistic & p-value* \\
\hline CH vs. CP & 1.161 & 0.254 \\
CU vs. CP & -.0724 & 0.474 \\
\hline
\end{tabular}

*Contrasts significant at $\mathrm{P}<0.05$

${ }^{\mathrm{a}} \mathrm{Chill}$ Hour Model= Predicted date of $90 \%$ bloom using the yearly average of $\Sigma \mathrm{CH}$ (Number of hours $\leq 45^{\circ} \mathrm{F}\left(7.2^{\circ} \mathrm{C}\right)$ ) from November $1^{\text {st }}$ until Nonpareil reached $400 \mathrm{CH}\left(\mathrm{CH}\right.$ Date) and yearly average $\Sigma \mathrm{GDH}^{\circ}$ from $\mathrm{CH}$ Date until Nonpareil reached $90 \%$ bloom at each site.

${ }^{\mathrm{b}}$ Utah Chill Units (Utah Model) $=$ Predicted date of $90 \%$ bloom in Nonpareil using yearly average $\Sigma \mathrm{CU}$ (Number of hours corresponding to a weighted unit; 1 hour $\leq 34^{\circ} \mathrm{F}=0 \mathrm{CU} ; 35-36^{\circ} \mathrm{F}=0.5 \mathrm{CU} ; 37-48^{\circ} \mathrm{F}=1 \mathrm{CU} ; 49-54^{\circ} \mathrm{F}=0.5 \mathrm{CU} ; 55-60^{\circ} \mathrm{F}=0 ; 61-65^{\circ} \mathrm{F}=-0.5 \mathrm{CU} ; 1$ hour $\left.>65^{\circ} \mathrm{F}=-1 \mathrm{CU}\right)$ from November $1^{\text {st }}$ until Nonpareil reached $300 \mathrm{CU}$ (CU Date) and yearly average $\Sigma \mathrm{GDH}^{\circ}$ from CU Date until Nonpareil reached $90 \%$ bloom at each site.

${ }^{c}$ Chill Portion $($ Dynamic Model $)=$ Predicted date of $90 \%$ bloom in Nonpareil using yearly average $\Sigma \mathrm{CP}$ (Number of hours corresponding to a weighted unit; 1 hour $\leq 34^{\circ} \mathrm{F}=0 \mathrm{CU} ; 35-36^{\circ} \mathrm{F}=0.5 \mathrm{CU} ; 37-48^{\circ} \mathrm{F}=1 \mathrm{CU} ; 49-54^{\circ} \mathrm{F}=0.5 \mathrm{CU} ; 55-60^{\circ} \mathrm{F}=0 ; 61-65^{\circ} \mathrm{F}=-0.5 \mathrm{CU} ; 1$ hour $\left.>65^{\circ} \mathrm{F}=-1 \mathrm{CU}\right)$ from November $1^{\text {st }}$ until Nonpareil reached $30 \mathrm{CP}\left(\mathrm{CP}\right.$ Date) and yearly average $\Sigma \mathrm{GDH}^{\circ}$ from $\mathrm{CP}$ Date until Nonpareil reached $90 \%$ bloom at each site.

For Mission in Butte County, the Calendar model tended to predict earlier dates

for Mission than the $\mathrm{CU}, \mathrm{CP}, \mathrm{CH}$ and Heat models for most years (Figure 12). Years

1999 and 2004 were largely overestimated in predicted bloom dates using the CU, CP, 
$\mathrm{CH}$ and Heat models (Figure 12). The CU and CP models most closely reflected the actual $90 \%$ bloom dates but the CU had smaller mean errors overall (Table 8).

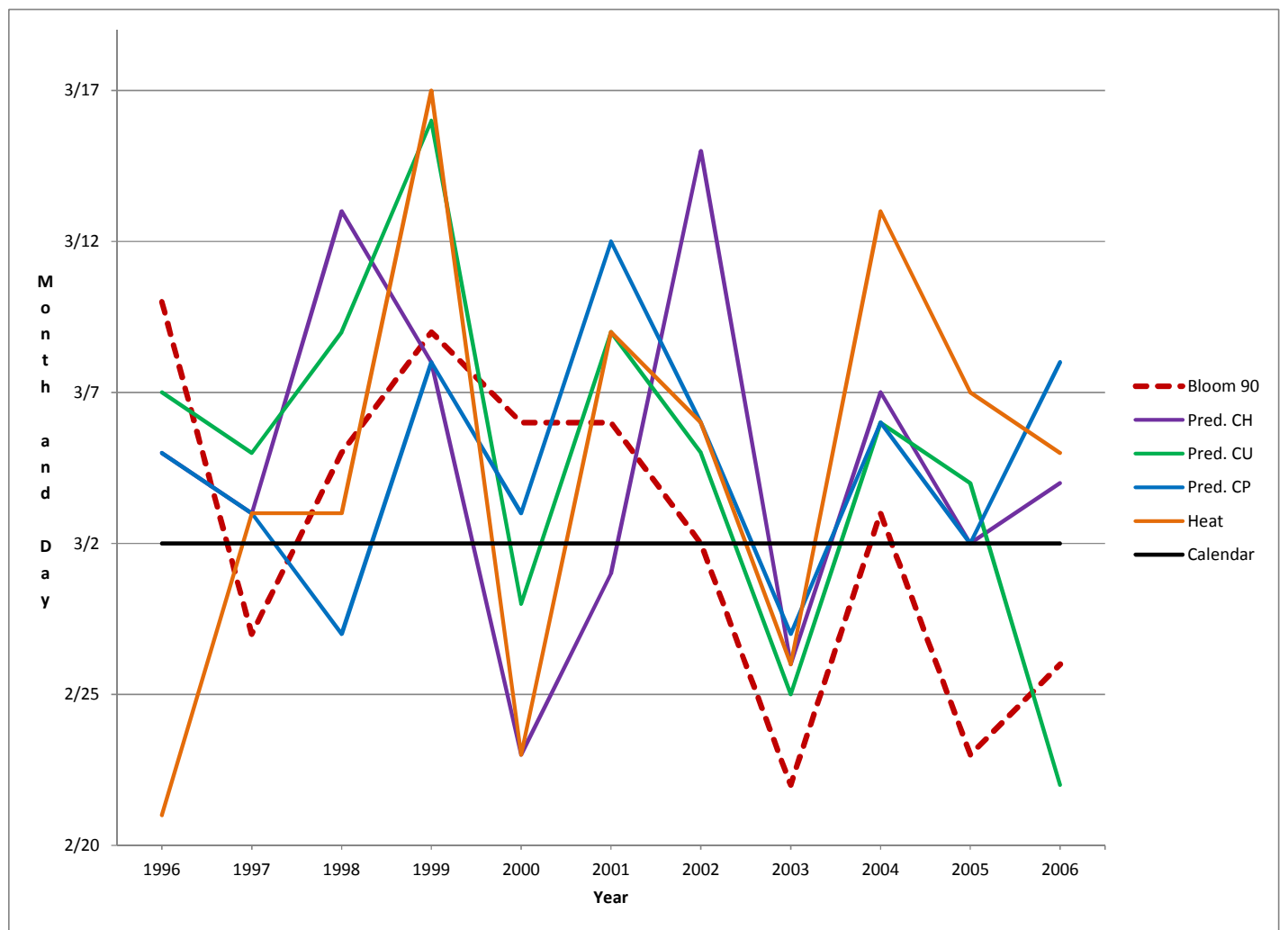

Figure 12. Butte County predicted dates of $90 \%$ Mission bloom using the $\mathrm{CH}, \mathrm{CU}, \mathrm{CP}$, Calendar and Heat models compared with the actual dates of $90 \%$ bloom

.${ }^{a}$ Calendar Model $=$ Predicted date of $90 \%$ bloom using the average yearly date of 90\% bloom for Nonpareil from 1996-2006 at Butte, San Joaquin and Kern Co. sites

${ }^{\mathrm{b}}$ Chill Hour Model $=$ Predicted date of $90 \%$ bloom using the yearly average of $\Sigma \mathrm{CH}$ (Number of hours $\leq 45^{\circ} \mathrm{F}\left(7.2^{\circ} \mathrm{C}\right)$ ) from November $1^{\text {st }}$ until Nonpareil reached $400 \mathrm{CH}$ (CH Date) and yearly average $\Sigma \mathrm{GDH}^{\circ}$ from $\mathrm{CH}$ Date until Nonpareil reached $90 \%$ bloom at each site.

${ }^{c}$ Utah Chill Units (Utah Model) $=$ Predicted date of $90 \%$ bloom in Nonpareil using yearly average $\Sigma \mathrm{CU}$ (Number of hours corresponding to a weighted unit; 1 hour $\leq 34^{\circ} \mathrm{F}=0 \mathrm{CU} ; 35-36^{\circ} \mathrm{F}=0.5 \mathrm{CU} ; 37-48^{\circ} \mathrm{F}=1 \mathrm{CU} ; 49-54^{\circ} \mathrm{F}=0.5 \mathrm{CU} ; 55-60^{\circ} \mathrm{F}=0 ; 61-65^{\circ} \mathrm{F}=-0.5 \mathrm{CU} ; 1$ hour $\left.>65^{\circ} \mathrm{F}=-1 \mathrm{CU}\right)$ from November $1^{\mathrm{st}}$ until Nonpareil reached $300 \mathrm{CU}$ (CU Date) and yearly average $\Sigma \mathrm{GDH}^{\circ}$ from CU Date until Nonpareil reached $90 \%$ bloom at each site.

${ }^{\mathrm{d}}$ Chill Portion (Dynamic Model) $=$ Predicted date of $90 \%$ bloom in Nonpareil using yearly average $\Sigma$ CP (Number of hours corresponding to a weighted unit; 1 hour $\leq 34^{\circ} \mathrm{F}=0 \mathrm{CU} ; 35-36^{\circ} \mathrm{F}=0.5 \mathrm{CU} ; 37-48^{\circ} \mathrm{F}=1 \mathrm{CU} ; 49-54^{\circ} \mathrm{F}=0.5 \mathrm{CU} ; 55-60^{\circ} \mathrm{F}=0 ; 61-65^{\circ} \mathrm{F}=-0.5 \mathrm{CU} ; 1$ hour $\left.>65^{\circ} \mathrm{F}=-1 \mathrm{CU}\right)$ from November $1^{\mathrm{st}}$ until Nonpareil reached $30 \mathrm{CP}\left(\mathrm{CP}\right.$ Date) and yearly average $\Sigma \mathrm{GDH}^{\circ}$ from $\mathrm{CP}$ Date until Nonpareil reached $90 \%$ bloom at each site.

${ }^{\mathrm{e}} \mathrm{Heat}=$ Predicted date of $90 \%$ bloom in Nonpareil using yearly average $\Sigma \mathrm{GDH}^{\circ}$ (Growing Degree Hours $=\Sigma\left(\mathrm{T}_{\mathrm{M}}-41.5^{\circ} \mathrm{F}\right)$ where $\mathrm{T}_{\mathrm{M}}=$ temperature measured at a given hour in the day; and where if $\mathrm{T}_{\mathrm{M}} \geq 98.5^{\circ} \mathrm{F}\left(35^{\circ} \mathrm{C}\right)$ or $\mathrm{T}_{\mathrm{M}} \leq 41.5^{\circ} \mathrm{F}\left(5^{\circ} \mathrm{C}\right), \mathrm{GDH}^{\circ}=0$; $\mathrm{GDH}^{\circ}$ are accumulated over a 24 hour period for a daily total) from January $1^{\text {st }}$ until the date Nonpareil reached $90 \%$ bloom at each site.

For the San Joaquin County site, Mission actual 90\% bloom dates occurred much earlier on average than the predicted dates by the $\mathrm{CU}, \mathrm{CP}, \mathrm{CH}$ and Heat models, especially after the year 2003 (Figure 13). The Calendar model had the smallest average error when predicting actual $90 \%$ bloom dates, although the CU and CP models closely reflect the actual $90 \%$ bloom dates. It is interesting to note that actual $90 \%$ bloom in 
Mission occurred much later during the years 1996 and 1998 compared with overall average date of March $4^{\text {th }}$ for San Joaquin County.

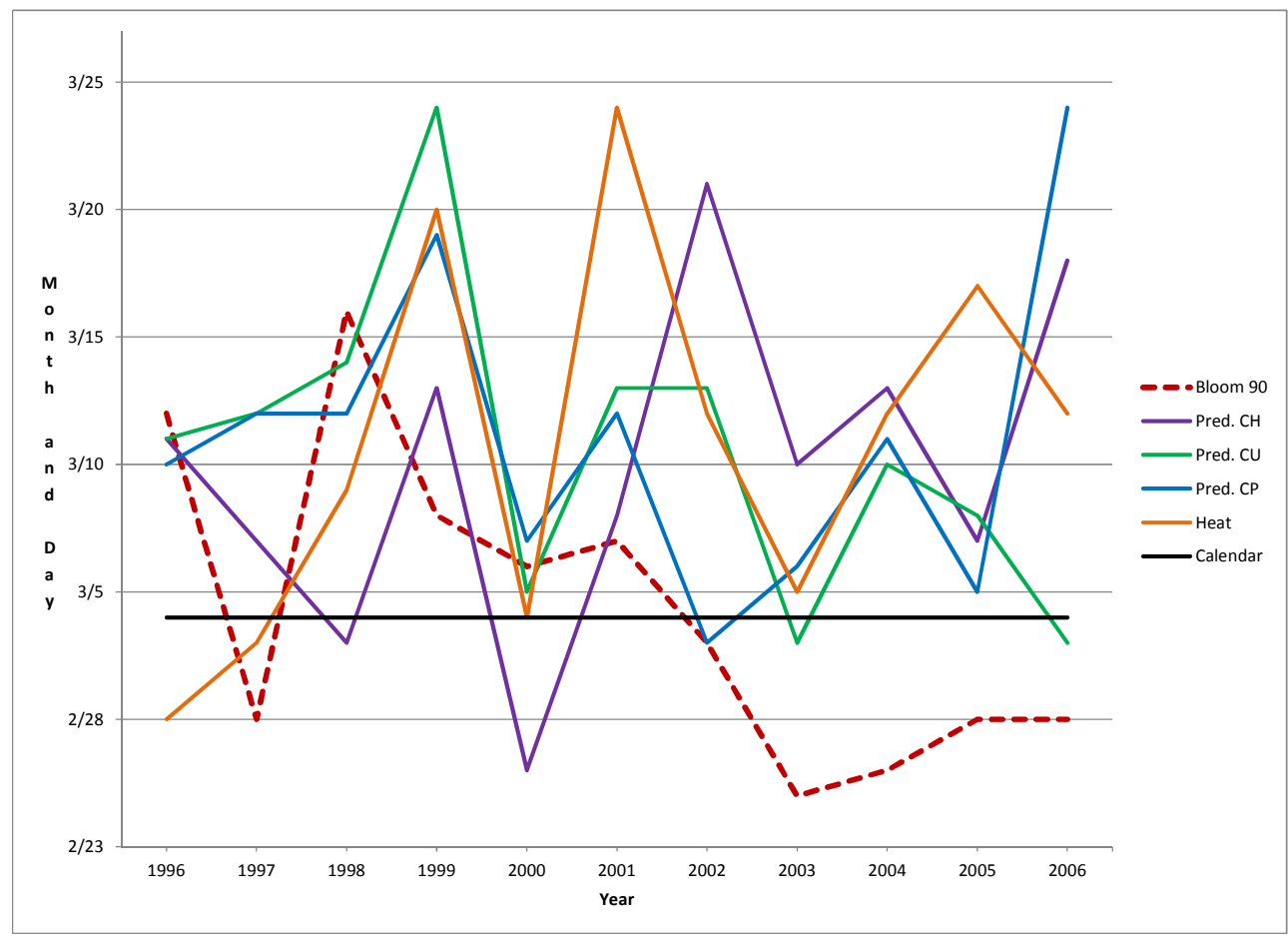

Figure 13. San Joaquin County predicted dates of $90 \%$ Mission bloom using the $\mathrm{CH}$, CU, CP, Calendar and Heat models compared with the actual dates of $90 \%$ bloom.

${ }^{a}$ Calendar Model= Predicted date of $90 \%$ bloom using the average yearly date of 90\% bloom for Nonpareil from 1996-2006 at Butte, San Joaquin and Kern Co. sites

${ }^{\mathrm{b}}$ Chill Hour Model $=$ Predicted date of $90 \%$ bloom using the yearly average of $\Sigma \mathrm{CH}$ (Number of hours $\left.\leq 45^{\circ} \mathrm{F}\left(7.2^{\circ} \mathrm{C}\right)\right)$ from November $1^{\text {st }}$ until Nonpareil reached $400 \mathrm{CH}\left(\mathrm{CH}\right.$ Date) and yearly average $\Sigma \mathrm{GDH}^{\circ}$ from $\mathrm{CH}$ Date until Nonpareil reached $90 \%$ bloom at each site

${ }^{c}$ Utah Chill Units (Utah Model) = Predicted date of $90 \%$ bloom in Nonpareil using yearly average $\Sigma \mathrm{CU}$ (Number of hours corresponding to a weighted unit; 1 hour $\leq 34^{\circ} \mathrm{F}=0 \mathrm{CU} ; 35-36^{\circ} \mathrm{F}=0.5 \mathrm{CU} ; 37-48^{\circ} \mathrm{F}=1 \mathrm{CU} ; 49-54^{\circ} \mathrm{F}=0.5 \mathrm{CU} ; 55-60^{\circ} \mathrm{F}=0 ; 61-65^{\circ} \mathrm{F}=-0.5 \mathrm{CU} ; 1$ hour $\left.>65^{\circ} \mathrm{F}=-1 \mathrm{CU}\right)$ from November $1^{\mathrm{st}}$ until Nonpareil reached $300 \mathrm{CU}$ (CU Date) and yearly average $\Sigma \mathrm{GDH}^{\circ}$ from CU Date until Nonpareil reached $90 \%$ bloom at each site.

${ }^{\mathrm{d}}$ Chill Portion (Dynamic Model) $=$ Predicted date of $90 \%$ bloom in Nonpareil using yearly average $\Sigma$ CP (Number of hours corresponding to a weighted unit; 1 hour $\leq 34^{\circ} \mathrm{F}=0 \mathrm{CU} ; 35-36^{\circ} \mathrm{F}=0.5 \mathrm{CU} ; 37-48^{\circ} \mathrm{F}=1 \mathrm{CU} ; 49-54^{\circ} \mathrm{F}=0.5 \mathrm{CU} ; 55-60^{\circ} \mathrm{F}=0 ; 61-65^{\circ} \mathrm{F}=-0.5 \mathrm{CU} ; 1$ hour $\left.>65^{\circ} \mathrm{F}=-1 \mathrm{CU}\right)$ from November $1^{\mathrm{st}}$ until Nonpareil reached $30 \mathrm{CP}(\mathrm{CP}$ Date $)$ and yearly average $\Sigma \mathrm{GDH}^{\circ}$ from $\mathrm{CP}$ Date until Nonpareil reached $90 \%$ bloom at each site.

${ }^{e}$ Heat $=$ Predicted date of $90 \%$ bloom in Nonpareil using yearly average $\Sigma \mathrm{GDH}^{\circ}$ (Growing Degree Hours $=\Sigma\left(\mathrm{T}_{\mathrm{M}}-41.5^{\circ} \mathrm{F}\right)$ where $\mathrm{T}_{\mathrm{M}}=$ temperature measured at a given hour in the day; and where if $\mathrm{T}_{\mathrm{M}} \geq 98.5^{\circ} \mathrm{F}\left(35^{\circ} \mathrm{C}\right)$ or $\mathrm{T}_{\mathrm{M}} \leq 41.5^{\circ} \mathrm{F}\left(5^{\circ} \mathrm{C}\right), \mathrm{GDH}^{\circ}=0$; GDH are accumulated over a 24 hour period for a daily total) from January $1^{\text {st }}$ until the date Nonpareil reached $90 \%$ bloom at each site.

Kern County $90 \%$ bloom dates for Mission occurred earlier than the predictive models for most years (Figure 14). The Calendar model again had the smallest average errors when predicting actual bloom dates while the other four predictive models tended to largely overestimate actual bloom, especially in the years 1999, 2002 and 2006. The 
$\mathrm{CU}$ and $\mathrm{CP}$ predictive dates were again very similar to each other and tended to have the

\section{smallest average errors overall.}

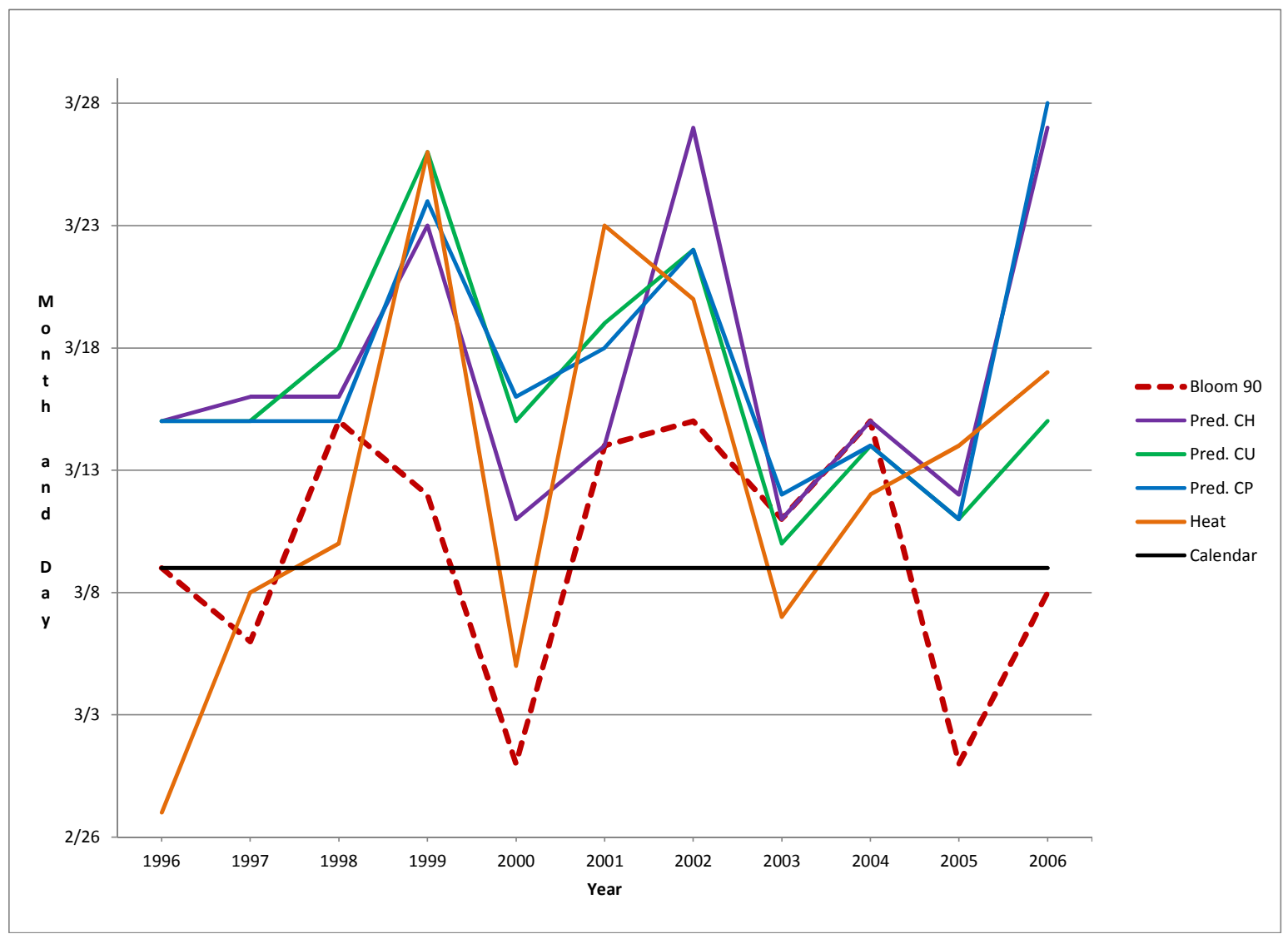

Figure 14. Kern County predicted dates of $90 \%$ Mission bloom using the $\mathrm{CH}, \mathrm{CU}, \mathrm{CP}$, Calendar and Heat models compared with the actual dates of $90 \%$ bloom

${ }^{a}$ Calendar Model= Predicted date of 90\% bloom using the average yearly date of 90\% bloom for Nonpareil from 1996-2006 at Butte, San Joaquin and Kern Co. sites

${ }^{\mathrm{b}} \mathrm{Chill}$ Hour Model= Predicted date of $90 \%$ bloom using the yearly average of $\Sigma \mathrm{CH}$ (Number of hours $\leq 45^{\circ} \mathrm{F}\left(7.2^{\circ} \mathrm{C}\right)$ ) from November $1^{\text {st }}$ until Nonpareil reached $400 \mathrm{CH}$ (CH Date) and yearly average $\Sigma \mathrm{GDH}^{\circ}$ from $\mathrm{CH}$ Date until Nonpareil reached $90 \%$ bloom at each site.

${ }^{c}$ Utah Chill Units (Utah Model) $=$ Predicted date of $90 \%$ bloom in Nonpareil using yearly average $\Sigma \mathrm{CU}$ (Number of hours corresponding to a weighted unit; 1 hour $\leq 34^{\circ} \mathrm{F}=0 \mathrm{CU} ; 35-36^{\circ} \mathrm{F}=0.5 \mathrm{CU} ; 37-48^{\circ} \mathrm{F}=1 \mathrm{CU} ; 49-54^{\circ} \mathrm{F}=0.5 \mathrm{CU} ; 55-60^{\circ} \mathrm{F}=0 ; 61-65^{\circ} \mathrm{F}=-0.5 \mathrm{CU} ; 1$ hour $\left.>65^{\circ} \mathrm{F}=-1 \mathrm{CU}\right)$ from November $1^{\text {st }}$ until Nonpareil reached $300 \mathrm{CU}$ (CU Date) and yearly average $\Sigma \mathrm{GDH}^{\circ}$ from CU Date until Nonpareil reached $90 \%$ bloom at each site.

${ }^{\mathrm{d}}$ Chill Portion (Dynamic Model) $=$ Predicted date of $90 \%$ bloom in Nonpareil using yearly average $\Sigma$ CP (Number of hours corresponding to a weighted unit; 1 hour $\leq 34^{\circ} \mathrm{F}=0 \mathrm{CU} ; 35-36^{\circ} \mathrm{F}=0.5 \mathrm{CU} ; 37-48^{\circ} \mathrm{F}=1 \mathrm{CU} ; 49-54^{\circ} \mathrm{F}=0.5 \mathrm{CU} ; 55-60^{\circ} \mathrm{F}=0 ; 61-65^{\circ} \mathrm{F}=-0.5 \mathrm{CU} ; 1$ hour $>65^{\circ} \mathrm{F}=-1 \mathrm{CU}$ ) from November $1^{\text {st }}$ until Nonpareil reached $30 \mathrm{CP}\left(\mathrm{CP}\right.$ Date) and yearly average $\Sigma \mathrm{GDH}^{\circ}$ from $\mathrm{CP}$ Date until Nonpareil reached $90 \%$ bloom at each site.

${ }^{\mathrm{e}} \mathrm{Heat}=$ Predicted date of $90 \%$ bloom in Nonpareil using yearly average $\Sigma \mathrm{GDH}^{\circ}$ (Growing Degree Hours $=\Sigma\left(\mathrm{T}_{\mathrm{M}}-41.5^{\circ} \mathrm{F}\right)$ where $\mathrm{T}_{\mathrm{M}}=$ temperature measured at a given hour in the day; and where if $\mathrm{T}_{\mathrm{M}} \geq 98.5^{\circ} \mathrm{F}\left(35^{\circ} \mathrm{C}\right)$ or $\mathrm{T}_{\mathrm{M}} \leq 41.5^{\circ} \mathrm{F}\left(5^{\circ} \mathrm{C}\right), \mathrm{GDH}^{\circ}=0 ; \mathrm{GDH}^{\circ}$ are accumulated over a 24 hour period for a daily total) from January $1^{\text {st }}$ until the date Nonpareil reached $90 \%$ bloom at each site. 


\section{Objective 2: Evaluate correlations between temperature patterns during bloom and}

\section{bloom length}

When looking at Nonpareil and Mission bloom length by site, the Kern site had a longer bloom length on average than either the Butte or San Joaquin County sites. There was a positive correlation between total accumulated $\mathrm{GDH}^{\circ}$ during bloom and bloom length in days for both Nonpareil and Mission (Figures 15 \& 16). When looking at the average $\mathrm{GDH}^{\circ}$ per day (total $\mathrm{GDH}^{\circ}$ during bloom divided by the number of days of bloom), there was no determinable relationship between bloom length and $\mathrm{GDH}^{\circ}$ during bloom for either variety (Table 9).

Table 9. Mean bloom length in Nonpareil and Mission in days by County

\begin{tabular}{ccccc}
\hline & Nonpareil & \multicolumn{3}{c}{ Mission } \\
\hline Site & Mean Days & $( \pm$ S.D.) & Mean Days & $( \pm$ S.D. $)$ \\
Butte & 9 & \pm 4.3 & 6 & \pm 1.9 \\
San Joaquin & 7 & \pm 2.2 & 9 & \pm 3.8 \\
Kern & 15 & \pm 5.1 & 17 & \pm 3.2 \\
\hline
\end{tabular}

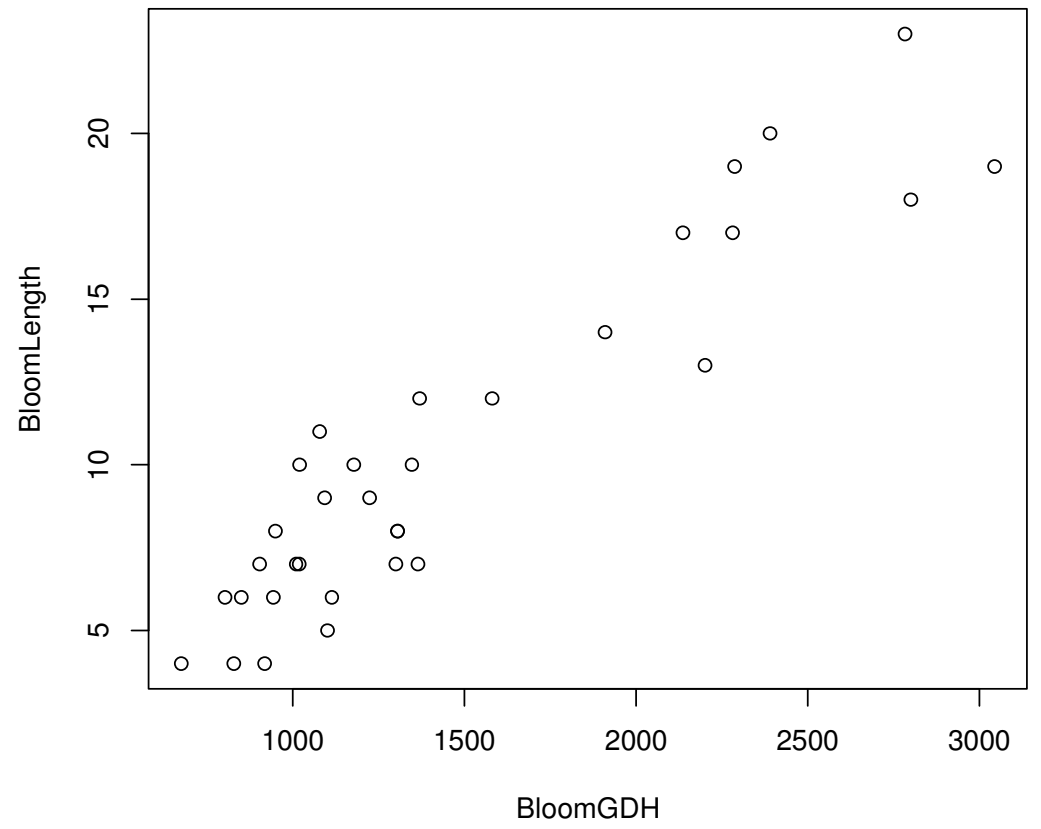

Figure 15. Scatterplot of bloom length (in days) versus $\mathrm{GDH}^{\circ}$ during bloom for Nonpareil. 


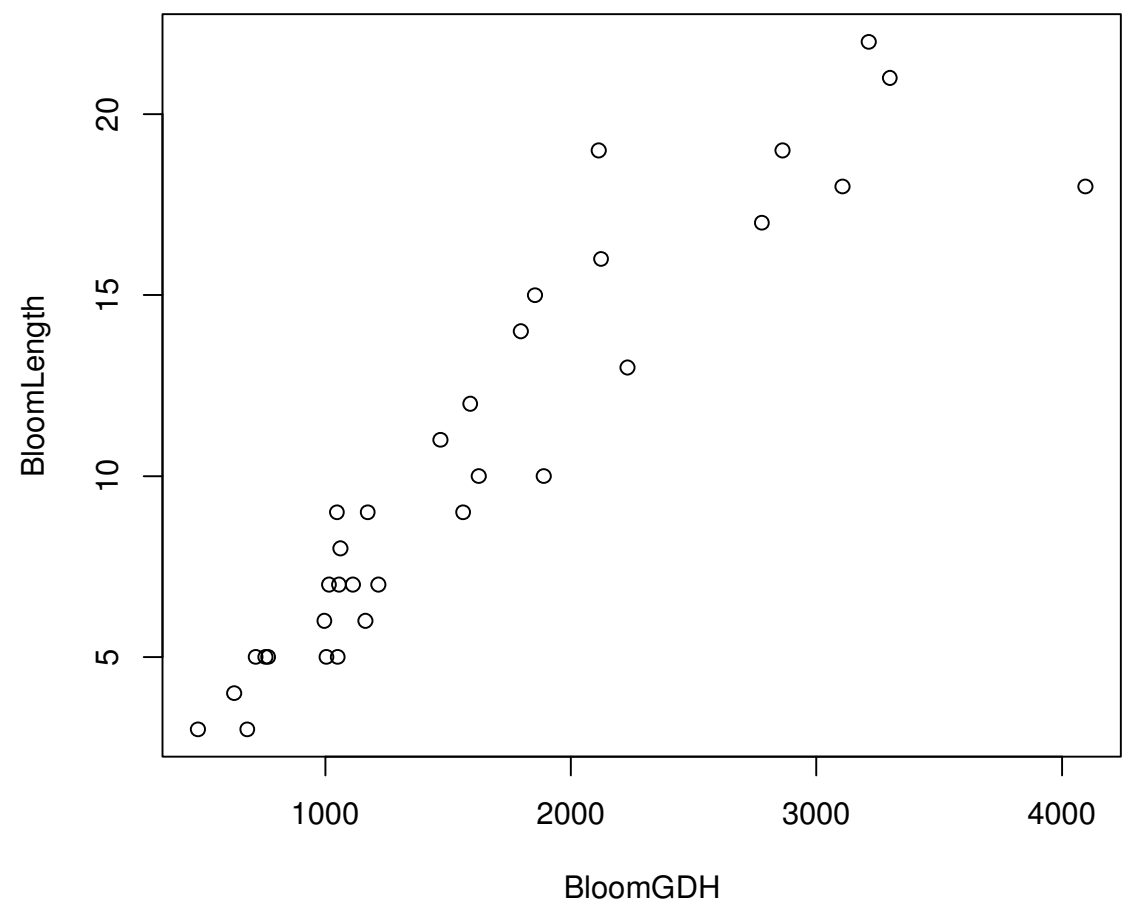

Figure 16. Scatterplot of bloom length (in days) versus $\mathrm{GDH}^{\circ}$ during bloom for Mission.

Objective 3: Evaluate correlations between the length of bloom, temperature patterns during bloom, and corresponding yields

Average Nonpareil yields were highest in Butte and Kern Counties while Mission yields were highest in Kern County (Table 10). There was no significant relationship between bloom length and yield in Nonpareil $(\mathrm{p}=0.56)$ or Mission $(\mathrm{p}=0.63)$ when controlling for site (Table 11). The pest damage factor was omitted for Mission due to missing values for some years.

Table 10. Almond yield in Nonpareil and Mission (lbs. /tree) by County

\begin{tabular}{ccccc}
\hline & Nonpareil & \multicolumn{3}{c}{ Mission } \\
\hline Site & Mean Yield & $\mathbf{( \pm \text { S.D.) }}$ & Mean Yield & $\mathbf{( \pm \text { S.D. } )}$ \\
\hline Butte & 28.9 & \pm 10.6 & 22.9 & \pm 10.4 \\
San Joaquin & 20.8 & \pm 9.5 & 20.8 & \pm 7.7 \\
Kern & 29.7 & \pm 9.4 & 26.1 & \pm 7.8 \\
\hline
\end{tabular}


Table 11. Multiple Regression Analysis of yield versus bloom length.

\begin{tabular}{cccc}
\hline Variety & Standard Error & t-statistic & p-value* \\
\hline Nonpareil & 0.68 & 0.59 & 0.56 \\
Mission & 0.92 & -0.49 & 0.63 \\
\hline $\begin{array}{l}\text { *Contrasts significant at } \mathrm{P}<0.05 \text {. Site and worm damage factors were controlled in Nonpareil, while only site was } \\
\text { controlled for in Mission. }\end{array}$
\end{tabular}

Nonpareil yield was significantly influenced by $\mathrm{GDH}^{\circ}$ during the first four days of bloom (10\% bloom date was considered the start of bloom) when controlling for worm damage, bloom length and site $(\mathrm{p}=0.0 .13)$ (Table 12). Each additional $\mathrm{GDH}^{\circ}$ during the first four days of bloom was correlated with a yield increase of 0.04 pounds per tree. Accumulated $\mathrm{GDH}^{\circ}$ during the first four days of Nonpareil bloom was significantly related to yield when not controlling for worm damage as well.

No significant relationship was found between $\mathrm{GDH}^{\circ}$ during the first four days of bloom and Mission yield while controlling for site and bloom length $(\mathrm{p}=0.14)$. The pest damage factor was omitted due to missing values for some years (Table 12).

Table 12. Multiple Regression Analysis of yield versus $\mathrm{GDH}^{\circ}$ during the first four days of bloom.

\begin{tabular}{cccc}
\hline Variety & Standard Error & t-value & p-value* \\
\hline Nonpareil & 0.02 & 2.67 & 0.013 \\
Mission & 0.02 & 1.5 & 0.14 \\
\hline
\end{tabular}

*Contrasts significant at $\mathrm{P}<0.05$. Bloom length, site and worm damage factors were controlled in Nonpareil, while only bloom length and site were controlled for in Mission. 


\section{CHAPTER}

\section{DISCUSSION AND CONCLUSIONS}

The purpose of this research project was to investigate the relationship between temperatures preceding almond bloom and bloom timing, between temperatures during bloom and bloom length in days, and to investigate the relationship between temperatures during bloom, bloom length and harvest yields.

\section{Objective 1. Evaluate correlations between temperature patterns prior to bloom and bloom timing}

For Nonpareil, the averaged $90 \%$ bloom dates across eleven years by site (Calendar model) better predicted the actual date of 90\% bloom than the Chill Hour $(\mathrm{CH})$, Chill Unit (CU), Chill Portion (CP) or Heat model. There was also no significant difference in average error between the Calendar and the $\mathrm{CP}$ model in predicting the actual date of $90 \%$ bloom in Nonpareil.

For Mission, the Calendar model better predicted the date of $90 \%$ bloom by year and site than the $\mathrm{CP}, \mathrm{CH}$ and Heat models in predicting $90 \%$ bloom, although the Calendar model was not statistically better at predicting the $90 \%$ bloom date than the $\mathrm{CU}$ model. There was also no significant difference in average error between the $\mathrm{CH}$ and $\mathrm{CP}$ models or the CU and CP models in predicting the date of $90 \%$ bloom for Mission.

\section{Calendar Model}

The Calendar Model was based on the hypothesis that bloom timing is better predicted using an average calendar date than specific temperature variables. Although the Calendar Model resulted in the smallest average errors when predicted bloom timing in both Mission and Nonpareil, it is difficult to use it for future predictions because its 
accuracy was measured against dates that had already occurred. Use of the Calendar Model's average bloom timing dates to predict bloom in the future would more clearly demonstrate whether it can be used as a viable model for commercial use.

\section{Heat Model}

The absence of significant differences between the Heat model and the averaged dates of $90 \%$ bloom for each variety and site indicates that this model was lacking explanatory factors relating to bloom timing. The Heat model solely accounted for Growing Degree Hour accumulation from January 1st until the date of $90 \%$ bloom for each variety, site and year. The model did not account for the chilling requirement factor which is an essential part of floral bud development prior to breaking dormancy and initiating growth in the early spring (Tombesi, et al., 2010).

Although research shows that almonds have a very low chilling requirement and thus satisfy this requirement by mid- December in Mediterranean climates (Tabuenca, 1972), bloom timing can be significantly altered by irregular chilling or lack of chilling during the endodormant period (Rodrigo \& Herrero, 2002) and may be prolonged by cool periods during the tree's ecodormancy period in the early spring (Hill 1985). The progress, intensity and date of chilling accumulation must be included into a predictive heat model to effectively assess bloom timing.

The minimum and maximum temperatures used for measuring effective heat accumulation, or Growing Degree Days (GDD) were 41.5 and $98.5 \mathrm{~F}$ ( $5^{\circ}$ and $35 \mathrm{C}$ ). These thresholds were used for both the Heat Model in objective one and for the GDH ${ }^{\circ}$ measured during bloom in objective three. This range was appropriate for temperatures measured after bloom to predict hull split dates in almonds (Tombesi, et al., 2010). The 
upper threshold was inconsequential because temperatures in early spring did not reach 98.5F during bloom, but the minimum threshold may have been too high to fully encompass heat sensed by floral buds prior to and during bloom. In apricot, there have been a variety of base temperature thresholds found for full bloom including $-2^{\circ} \mathrm{C}$ for earlier blooming cultivars (Ruml, et al., 2010), 4.5C (Richardson, et al., 1975) and 4.4C (Valentino, 1986). Temperatures below freezing have typically been disregarded as ineffective for growth and development and measured as "zero" in the GDD ${ }^{\circ}$ model (Ruml, et al., 2010). Temperatures just above the freezing temperature threshold may be important for almonds during their pre-bloom development.

In conclusion, the Heat Model may not have accurately predicted average dates of $90 \%$ bloom due to incorrect threshold levels used in the model. Additionally, the Heat Model did not take into account the possibility that temperature thresholds may vary throughout annual tree development.

\section{Chilling Models}

There are a variety of explanations for why the chilling models did not perform better against the Calendar model. For one, the date chosen to determine bloom timing was the date of $90 \%$ bloom, which typically occurred close to the end of the bloom period. The actual bloom start date occurred an average of five to fifteen days before the 90\% bloom date (Appendix A-C). Secondly, the three County sites were subjectively evaluated by different researchers, possibly creating variation in what is actually considered $90 \%$ bloom. Thirdly, the chilling requirements for both Nonpareil and Mission were evaluated using different chill models in various locations (CH in Davis, CU in Australia, CP generalized for the Central Valley; (Luedeling, et al., 2009; Rattigan 
\& Hill, 1986; Weinberger, 1950), respectively). Luedeling (2009) states that chill models must be specifically calibrated for microclimates and cannot be directly translated across locations (Luedeling, et al., 2009). More work has been done on Nonpareil than Mission because of the former's dominate status as the most popular and widely planted variety across the state. More confidence is associated with Nonpareil's chilling requirements (400 CH, 300 CU, 30 CP) than Mission's (500 CH, 320 CU, 38 CP; (Luedeling, et al., 2009; Rattigan \& Hill, 1986; Weinbaum, et al., 1984), respectively). The combination of inconsistent data on chilling models used in California and the ability to translate chilling requirements across locations and climates combined with the potential variation in actual bloom timing versus the date of $90 \%$ bloom may have contributed to the inability of the $\mathrm{CH}, \mathrm{CU}$ or $\mathrm{CP}$ models to outperform the Calendar models.

It is interesting to note that the Calendar model did not perform statistically better than the $\mathrm{CP}$ model in Nonpareil and the $\mathrm{CU}$ model in Mission, while the $\mathrm{CH}$ failed to compete with the Calendar model in both varieties. This may be attributed to the fact that issues arise with the $\mathrm{CH}$ model when temperatures below $45^{\circ} \mathrm{F}$ alternate with temperatures above $45^{\circ} \mathrm{F}$, resulting in a cancelling effect that is unaccounted for in the chilling hour model (Glozer \& Grant, 2005). Warmer temperatures that rise above a certain threshold lack the ability to promote dormancy break in floral and vegetative buds (Erez, 2000b). This cancelling effect commonly occurs in warm climates, such as California.

The CU and CP models both include controls for this cancelling effect in their calculations (Luedeling, et al., 2009). Both of these models were expected to perform better than the $\mathrm{CH}$ model which simply sums the hours below $45^{\circ} \mathrm{F}\left(7.2^{\circ} \mathrm{C}\right)$. 
Luedeling (2009) completed a study assessing 100 years of global temperatures using all three chilling models and ascertained that the $\mathrm{CP}$ model is the most consistent and accurate of the three (Luedeling, et al., 2009). When compared against each other, the $\mathrm{CP}$ did not perform better than the $\mathrm{CU}$ in Nonpareil and did not perform better than either the $\mathrm{CU}$ or $\mathrm{CH}$ in Mission. This may be explained by lack of research in determining the actual $\mathrm{CP}$ or $\mathrm{CH}$ chilling requirement of Mission in California.

\section{Almond Bloom Timing}

Several studies have confirmed a relationship between bloom timing and temperatures prior to and during bloom. Sharp changes in temperatures just before and during bloom have been observed to influence flower tolerance to freezing temperatures, with warming temperatures decreasing tree flower tolerance while cooler temperatures may increase pistil survival (E.L. Proebsting \& Mills, 1978). In apricot, warmer temperatures $\left(6-7.6^{\circ} \mathrm{C}\right.$ above average ambient temperatures) just before and during flowering resulted in an earlier bloom and rapid flowering over a shortened period of time, but were detrimental to final fruit yields (Rodrigo \& Herrero, 2002). In apple, bloom length was shortened and bloom density was low under warm weather conditions Abbott 1962.

Average dates of $90 \%$ bloom were fairly similar across sites with Butte being the earliest and Kern the latest to reach 90\% bloom for both Mission and Nonpareil. The northern portion of the Sacramento Valley, including Butte County, is above the Tule fog area. The lack of fog reduces air insulation and exposes orchards to greater amounts of cold temperatures, thus allowing them to complete their chill requirement earlier and bloom earlier (Cline, 2006). 


\section{Objective 2: Evaluate correlations between temperature patterns during bloom and bloom length}

Bloom length was found to be positively correlated with accumulated heat during bloom. Increases in pre-blossom temperatures have been discovered to speed up flower bud development and thus accelerate bloom progression (Degrandi-Hoffman, et al., 1996). It is interesting to note that bloom length was longest at the Kern site for Nonpareil, possibly due to warmer temperatures during the dormant period, causing inconsistent flowering.

It is difficult to determine whether heat truly influenced bloom length because longer bloom duration automatically accumulated more $\mathrm{GDH}^{\circ}$. A more controlled study would be needed to fully explore the effect of additional heat units on bloom length, as well as to understand temperature optimums and their effect on flowering rates within the range of temperatures measured throughout bloom.

\section{Objective 3: Evaluate correlations between the length of bloom, temperature patterns during bloom, and corresponding yields}

When performing a multiple regression analysis on bloom characteristics (defined by bloom length and $\mathrm{GDH}^{\circ}$ for the first four days of bloom) and yield and controlling for worm damage to nuts (primarily by navel orangeworm), $\mathrm{GDH}^{\circ}$ during the first four days of bloom was significantly related to yield in Nonpareil. This finding is consistent with previous pollination studies showing almond flower receptivity is correlated with timing and temperature. In terms of timing, flowers are most receptive to pollen from anthesis (day zero) to day four of bloom (Kodad \& Socias i Company, 2009). This period is known as the effective pollination period (EPP) and involves several complicated factors, 
including effective bloom overlap timing, pollen compatibility across cultivars, orchard planting arrangement, healthy honey bee colonies and favorable weather conditions during bloom (Connell 2000).

The finding that each additional $\mathrm{GDH}^{\circ}$ during bloom in Nonpareil was correlated with a 0.4 pound per tree yield increase was further evidence that almond flower receptivity and possibly honey bee good bee hours (temperatures $59-100^{\circ} \mathrm{F}$ or $15-38^{\circ} \mathrm{C}$ with winds below $15 \mathrm{mph}$ and no rain) are positively affected by warming temperatures. Previous studies have outlined several optimal temperatures for pollination; specifically, anther pollen shed $\left(65-80^{\circ} \mathrm{F}\right.$ or $\left.18.3-26.6^{\circ} \mathrm{C}\right)$, pollen grain germination, $\left(50-70^{\circ} \mathrm{F}\right.$ or $10-$ $\left.21^{\circ} \mathrm{C}\right)$ and pollen tube growth $\left(70-87^{\circ} \mathrm{F}\right.$ or $\left.21-30.5^{\circ} \mathrm{C}\right)($ Connell, 2000). In Prunus species, studies have shown that exposure to temperatures above the upper threshold decreases pollen viability, pollen germination and nut set (Couto, Raseira, Herter \& Silva, 2010; Connell, 2000) while below threshold temperatures decrease growth and prolong bloom (Byrne \& Bacon, 1992). A rapid increase in temperatures during bloom caused desynchronization in pollen tube growth and stigma receptivity, resulting in decreased fruit set in peach (Hedhly, Hormanza \& Herrero, 2008) and apricot (Egea \& Burgos, 1995).

It is important to note that yield increases do not exponentially increase with increasing temperature. As temperatures reach upper thresholds for pollen and ovule viability, as well as honey bee flight, yields have the potential to decrease. High temperatures over $70-80^{\circ} \mathrm{F}$ rarely occur in early spring during almond bloom and yield losses due to heat spells are less likely to occur. 
It would have been interesting to correlate temperatures prior to bloom and just after bloom with yield in this study. Nava et al. (2009) found that increasing temperatures above $25^{\circ} \mathrm{C}(77 \mathrm{~F})$ during the pre-bloom and bloom stages delayed fertilization and resulted in lowered almond nut set (Nava, et al., 2009). Tombesi positively correlated GDD during 30, 50 and 90 day periods after bloom with hullsplit timing, suggesting that nut development continues to be dependent on temperature after bloom (Tombesi, et al., 2010). Pre-bloom temperatures were negatively correlated with double kernels in almonds, leading to a conclusion that ovule viability is related to increasing temperatures just before bloom (Egea \& Burgos, 1995).

A study on honeybee flight activity found that pollen foraging bees increase their activity as a function of temperature, colony size, time of day and interaction with the adult bee population (Danka, Sylvester \& Boykin, 2006). Colony size and strength varied in response to temperature fluctuations throughout the season with coinciding increases in flight and population with temperatures up to a threshold (Danka et al., 2006). Weather must not only be suitable within "good bee hours" parameters (no rain, no wind above $15 \mathrm{mph}$, temperatures $59-85^{\circ} \mathrm{F}$ ) for optimal cross pollination (Lampinen, et al., 2002; Thorp, 1996). This study assumed that honey bee colony strength and location within each orchard site were optimal throughout the EPP for each year and variety. $\mathrm{GDH}^{\circ}$ parameters during bloom included the optimal temperature range for bee activity, but "good bee hours" but were not studied discretely because they were not included in the data set for Kern or San Joaquin County.

No significant relationship was found between Mission bloom length or $\mathrm{GDH}^{\circ}$ during bloom and crop yield. This may be attributed to the fact that the pest damage 
factor was omitted due to missing values for some years. The Butte, San Joaquin and Kern sites also included yield data on hull rot, alternaria and gumming on nuts for some years (Lampinen, et al., 2002), but not all, therefore this information could not be used to correlate with yields in either variety.

Additional factors influencing final crop yields which were not accounted for in this study include the temperatures, stresses and yields from the previous growing season. Murua et al. (1994) found that alternate bearing habits in almonds vary by climate and developed a model accounting for past yields and the weather during bloom (frost days and rainfall) to predict future crop yields (Murua, 1994), while Viti and Monteleone (1991) found that high winter temperatures and drought conditions during the previous summer contributed to low yields and flower anomalies in almonds (Viti \& Monteleone, 1991).

Relative humidity or rainfall during bloom would have been interesting to include as a variable affecting crop yields. A study found that anther dehiscence decreases with increased relative humidity during bloom, resulting in pollen failures and poor nut set (Gradziel \& Weinbaum, 1999). Rain affects pollen grain adhesion to floral stigmas in almond (Ortega, et al., 2007).

\section{Differences between Nonpareil and Mission}

In addition to their bearing and growth habits, size and shape of the tree and popularity, Nonpareil and Mission differ in flowering time. Flowering time is a genetic trait which can be influenced by seasonal patterns, but is largely consistent due to evolutionary adaption over thousands of years (Kochmer and Handel, 1986). Different flowering times are the result of varied timing in development over the late fall and 
winter seasons, as well as genotype (Vargas \& Romero, 2001). As a late bloomer, Mission is genetically programmed to begin growth after a larger chilling requirement is reached and thus is released from dormancy at a later stage than Nonpareil. As an early bloomer, Nonpareil is often exposed to colder temperatures during ecodormancy and bloom than Mission. Ruiz (2008) found that late flowering apricot cultivars with high chilling requirements resulted in increased percentages of abscised buds than earlier flowering apricot cultivars (Ruiz, et al., 2008).

The fact that the trees at each site bloomed within three days of each other in Nonpareil and within a week at each site for Mission for all eleven years suggests that variety and genotype is more highly correlated with bloom timing than chilling or heat requirements during the pre-bloom period. This is confirmed by Weinbaum's (1989) study comparing peach and almond developmental processes with temperature optimums. It was found that species and variety more greatly influenced temperature dependent processes, specifically pollen development, tube elongation and germination timing, than chill requirement (Weinbaum, Polito \& Muraoka, 1989). Genetic studies that found flowering time is related to a major gene and two quantitative trait loci in almond suggest that there is a genotype related control in each variety that influences bloom timing more than heat or chilling accumulation (Silva, Garcia-Mas, Sanchez-Perez, Arus \& Oliveira, 2005).

\section{Conclusion}

As their international popularity grows, demands are driving almond acreage to continue to increase across California. Further studies on varietal chilling requirements relating to specific microclimates within the state will better assist growers in reducing 
the chances of missed bloom overlap. Chilling models must also be studied for accuracy and regional application in order to increase understanding of the factors affecting almond bloom timing and length of bloom as well as and the relationship between bloom characteristics and effective nut set.

The first observations were that bloom timing in Nonpareil and Mission are better predicted using an average calendar date than either chilling units (CU), chilling hours $(\mathrm{CH})$, chilling portions $(\mathrm{CP})$, growing degree hours $\left(\mathrm{GDH}^{\circ}\right)$, or a combination of these values. When solely temperature data were used to predict bloom timing in Nonpareil, models incorporating either chilling units or chilling portions generally performed better than chilling hours. There was no difference in predictive error between models with chilling units, portions or hours when predicting bloom timing in Mission.

The second major findings were that bloom length is positively correlated with increasing $\mathrm{GDH}^{\circ}$ in both Nonpareil and Mission, but temperature optimums were not studied, and it can be assumed that this relationship will be eventually limited when temperatures reach an upper threshold.

The last major findings were that yield is positively correlated with $\mathrm{GDH}^{\circ}$ in Nonpareil but not in Mission. In Nonpareil, a yield increase of 0.04 pounds per tree was associated with each additional $\mathrm{GDH}^{\circ}$. Accumulated $\mathrm{GDH}^{\circ}$ during the first four days of Nonpareil bloom was significantly related to yield when not controlling for worm damage as well. No significant relationship was found between $\mathrm{GDH}^{\circ}$ and Mission yield.

In conclusion, climate continues to strongly influence where almonds are grown across California. Growers must take care to cultivate varieties in climates with adequate chilling, but also to protect young shoots and buds from frost damage. Further research is 
needed on specific temperature thresholds and their relationship to physiological changes during almond bloom and pollination. However, the simple practice of monitoring chilling and heat accumulation will allow growers to anticipate flowering; prepare to optimize bee activity during bloom and plan for possible crop losses during extremely warm bloom periods. 


\section{REFERENCES}

Abbott, D. L. (1962). The effect of four controlled winter temperatures on the flowering and fruiting of the apple. Journal of Horticultural Science, 87, 272-284.

Alonso, J., Anson, J., Espiau, M., \& Socias i Company, R. (2005). Determination of endodormancy break in almond flower buds by a correlation model using the average temperature of different day intervals and its application to the estimation of chill and heat requirements and blooming date. J. Am. Soc. Hort. Sci., 130(308318).

Alonso, J. M., Espiau, M. T., Anson, J. M., \& Company, R. S. i. (2003). Development of a method to estimate flower bud dormancy breaking in almond. Paper presented at the Meeting of the Mediterranean Research Group for Almond and Pistachio.

Alonso, J. M., \& Socias i Company, R. (2009). Chill and heat requirements for blooming of the CITA Almond Cultivars. Paper presented at the ISHS.

Alston, J. A., Christian, J., Murua, J. R., \& Sexton, R. J. (1993). Restricting flow of almonds to export markets may raise profits. California Agriculture, 47(6), 7-10.

Anderson, J. L., Kesner, C. D., \& Richardson, E. A. (1986). Validation of chill unit and flower bud phenology models for "Montmorency" sour cherry. Acta Horticulturae, 184, 71-77.

Anderson, J. V., Chao, W. S., \& Horvath, D. P. (2001). A current review on the regulartion of dormancy in vegetative buds. Weed Science, 49, 581-589.

Andrews, P. K., Proebsting, E. L., \& Gross, D. C. (1986). Ice nucleation and supercooling in freeze sensitive peach and sweet cherry tissues. Journal of American Society of Horticultural Sciences, 108, 755-759.

Asai, W. K., Micke, W. C., Kester, D. E., \& Rough, D. (1996). The evaluation and selection of current varieties. In W. C. Micke (Ed.), Almond Production Manual (pp. 52-60): UC ANR.

Ashcroft, G. L., Richardson, E. A., \& Seeley., S. D. (1977). A statistical method of determining chill unit and growing degree hour requirements for deciduous fruit trees. HortScience, 12(4), 347-348.

Austin, P. T., Hewett, E. W., Noiton, D., \& Plummer, J. A. (1998). Adjusting growth stage values to develop a linear scale for apricot flower bud phenology. HortScience, 33(7), 1141-1144.

Baskerville, G. L., \& Emin., P. (1969). Rapid estimation of heat accumulation from maximum and minimum temperatures. Ecology, 50(3), 514-517.

Beattie, B. B., \& Folley, R. R. W. (1977). Production variability in apple crops. Scientia Horticulturae, 6, 271-279.

Beattie, B. B., \& Folley, R. R. W. (1978). Production variability in apple crops II: the long term behaviour of the English crop. Scientia Horticulturae, 8, 325-332.

Beppu, K., Okamoto, S., Sugiyama, A., \& Kataoka, I. (1997). Effects of temperature on flower development and fruit set of "Satohnishiki" sweet cherry (Prunus avium). Journal of Japanese Society of Horticultural Science, 65, 707-712.

Bonhomme, M., Rageau, R., Richard, J. P., Erez, A., \& Gendraud, M. (1999). Influence of three contrasted climatic conditions on endodormant vegetative and floral 
peach buds- analyses of their intrinsic growth capactiy and their potential sink strength compared with adjacent tissues. Scientia Horticulturae, 80, 157-171.

Boriss, H., \& Brunke, H. (2005). Commodity Profile: Almonds. In A. M. R. Center (Ed.): Agricultural Issues Center, University of California.

Bosch, J., Kemp, W. P., \& Peterson, S. S. (2000). Management of Osmia lignaria (Hymenoptera: Megachilidae) populations for almond pollination: methods to advance bee emergence. Environmental Entomology, 29(5), 874-883.

Bradley, L., \& Maurer, M. (2002). Deciduous fruit and nuts for the low desert. In U. o. Arizona (Ed.), (Vol. March, pp. 1-9): University of Arizona.

Browicz, K., \& Zohary, D. (1996). The genus Amygdalus L. (Rosaceae): species relationships, distribution and evolution under domestication. Genetic Resources Crop Evolution, 43(3), 229-247.

Brown, D. S. (1960). The relation of temperature to the growth of apricot flower buds. Proceedings for the American Society of Horticultural Sciences, 75, 138-147.

Browning, G., \& Miller, J. M. (1992). The association of year-to-year variation in average yield of pear. Paper presented at the Conference in England with weather variables, England.

Burgett, D. M., Fisher, G. C., Mayer, D. F., \& Johansen, C. A. (1984). Evaluating honey bee colonies for pollination: a guide for growers and beekeepers. In O. S. U. E. Service (Ed.), (Vol. 245). Corvallis: United States Department of Agriculture.

Butterfield, H. M. (1963). A History of Subtropical Fruits and Nuts in California: University of California, Division of Agricultural Sciences, Agricultural Extension Service.

Byrne, D. H., \& Bacon, T. (1992). Chilling estimation: its importance and estimation. The Texas Horticulturist, 18(8), 5, 8-9.

California, A. B. o. (2010a). The 2010 Almond Almanac. In A. B. o. California (Ed.), (pp. 17). Modesto: Almond Board of California.

California, A. B. o. (2010b). Good Manufacturing Practices Retrieved May 20, 2011, from

http://www.almondboard.com/HANDLERS/FOODQUALITYSAFETY/GMPS/P ages/Default.aspx

California, A. B. o. (2010c). Growers Page Retrieved May 15, 2011, from http://www.almondboard.com/growers/Pages/Default.aspx

Camazine, S. (1993). The regulation of pollen foraging by honey bees: how foragers assess the colony's need for pollen. Behavioral Ecology and Sociobiology, 32(4), 265-272.

Cesaraccio, C., Spano, D., Duce, P., \& Snyder, R. L. (2001). An improved made for determining degree-day values from daily temperature data. International Journal of Biometeorology, 45, 161-169.

Chandler, W. H. (1942). Deciduous Orchards. Philidelphia. Chandler, W. H., \& Tufts, W. P. (1934). Influence of the rest period on opening of buds of fruit trees in spring and on development of flower buds of peach trees. Proc. Am. Soc. Hort. Sci., 30, 180-186.

Citadin, I., Raseira, M. C. B., Herter, F. G., \& Silva, J. B. (2001). Heat requirement for blooming and leafing in peach. HortScience, 36, 305-307. 
Cline, H. (2006). Crop impact uncertain: Hard freeze hits early almond bloom. Western Farm Press. March 18, 2006.

Connell, J.H. (2000). Pollination of almonds: practices and problems. HortTechnology, 10, 116-119.

Connell, J.H. (2011). [Email communication].

Connell, J. H., Asai, W. K., \& Meith, H. C. (1996). Orchard Floor Management. In W. C. Micke (Ed.), Almond Board Manual (pp. 196-201): UC ANR.

Corelli-Grappadelli, L., \& Lakso, A. N. (2002). Fruit development in deciduous tree crops as affected by physiological factors and environmental conditions. Paper presented at the XXVI International Horticultural Congress: Key Processes in the Growth and Cropping of Deciduous Fruit and Nut Trees.

Couto, M., Raseira, M.C.B., Herter, F.G. \& Silva, J.B. (2010). Influence of high temperatures at blooming time on pollen production and fruit set of peach "Maciel" and "Granada." Acta Horticulturae, 872, 225-230.

Cristoso, C. (2002). How do we increase peach consumption? Acta Horticulturae, 592, 601-605.

Danka, R.G., Sylvester, H.A., \& Boykin, D. (2006). Environmental influences on flight activity of USDA-ARS Russian and Italian stocks of honey bees (Hymenoptera: Apidae) duering almond pollination. Journal of Economic Entomology, 99(5), 1565-1570.

Davison, R. M., \& Young, H. (1973). Seasonal changes in the level of abscisic acid in xylem sap of peach. Plant Science Letters, 2(2), 79-82.

Degrandi-Hoffman, G., Thorp, R., Loper, G., \& Eisikowitch, D. (1992). Identification and Distribution of Cross-Pollinating Honey-Bees on Almonds. Journal of Applied Ecology, 29(1), 238-246.

Degrandi-Hoffman, G., Thorp, R., Loper, G., \& Eisikowitch, D. (1996). Describing the progression of almond bloom using accumulated heat units. Journal of Applied Ecology, 33, 812-818.

Delaplane, K. S., \& D.F.Mayer. (2000). Crop pollination by bees: CABI.

Denisov, V. P. (1988). Almond genetic resources in the USSR and their use in production and breeding. Acta Horticulturae, 224, 229-306.

Dennis, F. G. (1979). Factors affecting yield in apple with emphasis on "delicious". Horticultural Reviews, 1, 395-422.

Dicenta, F., Ortega, E., Cánovas, J. A., \& Egea, J. (2002). Self-pollination vs. crosspollination in almond:Pollen tube growth, fruit set and fruit characteristics. Plant Breeding, 121, 163-167.

Doll, D. A. (2010). Orchard tasks to help prevent frost damage.

Duncan, R. A. (2010). Almond Orchard Design Almond Orchard Design (Vol. May 2010, 15.2). Stanislaus: UC Cooperative Extension.

Duncan, R. A., Verdegaal, P. S., Holtz, B. A., Doll, D. A., Klonsky, K. A., \& Moura, R. L. D. (2011). Sample costs to establish an almond orchard and produce almonds. In U. o. C. C. Extension (Ed.). San Joaquin County.

Egea, J., \& Burgos, L. (1995). Double kernelled fruits in almond (Prunus dulcis Mill.) as related to pre-blossom temperatures. Annals of Applied Biology, 126, 163-168. 
Egea, J., Ortega, E., Martinez-Gomez, P., \& Dicenta, F. (2003). Chilling and heat requirements of almond cultivars for flowering. Environmental and Experimental Botany, 50, 79-85.

Erez, A. (2000a). Bud dormancy, phenomenon, problems and soluations in the tropics and subtropics. In A. Erez (Ed.), Temperate Fruit Crops in Warm Climates. Boston: Kluwar Academic Publishers.

Erez, A. (2000b). Bud dormancy; phenomenon, probloems and soluations in the tropics and subtropics. In A. Erez (Ed.), Temperate Fruit Crops in Warm Climates (pp. 17-48). Boston: Kluwar Academic Publishers.

Erez, A., Fishman, S., Gat, Z., \& Couvillon, G. A. (1988). Evaluation of winter climate for breaking bud rest using the dynamic model. Acta Horticulturae, 232, 76-89.

Faust, M. (1989a). Physiology of Temperate Zone Fruit Trees. New York: John Wiley \& Sons.

Faust, M. (1989b). Physiology of Temperate Zone Fruit Trees. New York: John Wiley \& Sons.

Fishman, S., Erez, A., \& Couvillon, G. A. (1987a ). The temperature dependence of dormancy breaking in plants: Two-step model involving a co-operation transition. Journal of Theoretical Biology, 124, 437-483.

Fishman, S., Erez, A., \& Couvillon, G. A. (1987b). The temperature dependence of dormancy breaking in plants: Computer simulation of processes studied under controlled emperatures. Journal of Theoretical Biology, 126(309-321).

Glozer, K., \& Grant, J. A. (2005). Use of the Dynamic Model and Chill Portions to time chemical rest-breaking treatments in 'Bing' sweet cherry. In C. C. A. Board (Ed.): University of California Cooperative Extension.

Goldwin, G. K. (1992). Environmental and internal regulation of fruiting, with particular reference to Cox's Orange Pippin apple. In C. Marshall \& J. Grace (Eds.), Fruit and seed production: Aspects of development, environment physiology and ecology (pp. 75-100). Cambridge, UK: Cambridge University Press.

Gradziel, T. M. (2009). Almond (Prunus dulcis) Breeding. In S. M. Jain \& P. M. Priyadarshan (Eds.), Breeding Plantation Tree Crops: Temperate Species. New York: Springer.

Gradziel, T. M., \& Weinbaum, S. A. (1999). High relative humidity reduces anther dehiscence in apricot, peach and almond. HortScience, 34, 322-325.

Grasselly, C., \& Gall, H. (1967). Etude sur la posibilite de combinaison de quelques caracteres agromiques chez l'amandier Cristomorto hybride par trois autres varietes. Annals of Amelioration of Plantes, 17, 83-91.

Griggs, W. H., \& Iwakiri, B. T. (1964). Timing is critical for effective cross-pollination of almond flowers. California Agriculture, 18, 6-7.

Hawker, J. S., \& Buttrose, M. S. (1979). Development of the Almond Nut (Prunus dulcis (Mill.) D. A. Webb). Anatomy and Chemical Composition of Fruit Parts from Anthesis to MaturityAnnals of Botany, 46(3), 313-321.

Hedhly, A., Hormanza, J., \& Herrero, M. (2008). The effect of temperature on pollen germination, pollen tube growth and stigmatic receptivity in peach. Plant Biology, 7(5), 476-483. 
Hendricks, L. (1996). Orchard planning, design and development. In W. C. Micke (Ed.), Almond Production Manual (pp. 47-51): UC ANR.

Hendricks, L., \& Duncan, R. (2001). In-Field Chipping and Shredding of Almond Prunings as an Alternative to Burning. Final report to Almond Board of California.

Hill, S. J., Stephenson, D. W., \& Taylor, B. K. (1985). Almond pollination studies: pollen production and viability, flower emergence and cross-pollination tests. Australian Journal of Experimental Agriculture, 25(3), 697-704.

Holtz, B. A. (2009). Spring prevention of almond diseases, Western Farm Press.

Idso, S. B., Jackson, R. D., Pinter, P. J., Reginato, R. J., \& Hatfield, J. L. (1981). Normalizing the stress-degree day parameter for environmental variability. Agricultural Meteorology, 24, 45-55.

IPM-ManualGroup. (1985). Integrated pest management for almonds. University of California Division of Agriculture and Natural Resources, Berkeley.

Jackson, D. (1999). Almond. In D. Jackson \& D. McNeil (Eds.), Temperate and subtropical fruit production (pp. 332): CABI.

Jackson, J. E., \& Hamer, P. J. C. (1980). The causes of year to year variation in the average yield of Cox's Orange Pippin apple in England. Journal of Horticultural Science, 55, 149-156.

Jackson, J. E., Hamer, P. J. C., \& Wickenden, M. F. (1983). Effects of early temperatures on the set of fruits of Cox's Orange Pippin apple and year to year variation in its yields. Acta Horticulturae, 139, 75-83.

Janick, J., \& Paull, R. E. (2008). The encyclopedia of fruit \& nuts: CABI.

Jenkins, D. J., Kendall, C. W., Marchie, A., Parker, T. L., Connelly, P. W., Qian, W., . . Spiller, G. A. (2002). Dose response of almonds on coronary heart disease risk factors: blood lipids, oxidized low-density lipoproteins, lipoprotein(a), homocysteine, and pulmonary nitric oxide: a randomized, controlled, crossover trial. Circulation, 106(11), 1327-1332.

Kester, D. E., \& Gradziel, T. M. (1996). Almonds. In J. Janick \& J. N. Moore (Eds.), Fruit Breeding, Vol. III: Nuts (Vol. 3, pp. 700-710). New York: John Wiley and Sons, Inc.

Kester, D. E., Gradziel, T. M., \& Grasselly, C. (1991). Almonds (Prunus). Paper presented at the Genetic Resources of Temperate Fruit and Nut Crops, The Netherlands.

Kester, D. E., \& Grasselly, C. (1987). Almond rootstocks In R. C. Rom \& R. F. Carlson (Eds.), Rootstocks for fruit crops (pp. 265-293). New York: Wiley.

Kester, D. E., \& Griggs., W. H. (1959). Fruit setting in the almond: pattern of flower and fruit drop. Proceedings for the American Society of Horticultural Sciences, 74, 214-219.

Kester, D. E., Kader, A., \& Cunningham, S. (1993). Almonds Encyclopedia of Science, Technology and Nutrition (pp. 121-126). London: Academic Press.

Kester, D. E., Martin, G. C., \& Labavitch, J. M. (1996). Growth and Development. In W. C. Micke (Ed.), Almond Production Manual (pp. 90-97): UC ANR.

Kester, D. E., Raddi, P., \& Asay, R. (1973). Correlation among chilling requirements for germination, blooming and leafing in almond Genetics, 74, 135. 
Kester, D. E., Raddi, P., \& Asay, R. (1977). Correlations of chilling requirements for germination, blooming and leafing within and among seedling populations of almond. Journal of American Society of Horticultural Sciences, 102(2), 45-148.

Kester, D. E., \& Ross, N. W. (1996). History. In W. C. Micke (Ed.), Almond Production Manual (pp. 1-2). Oakland, CA: University of California Division of Agriculture and Natural Resources.

Kochmer, J.P. \& Handel, S.N. (1986). Constraints and competition in the evolution of flowering phenology. Ecological Monographs, 56(4), 303-325.

Kodad, O., \& Socias i Company, R. (2009). Effect of pollination time on fruit set in an authogamous almond cultivar. Journal of Horticultural Science and Biotechnology, 84(3), 350-354.

Lamp, B. M., Connell, J. H., Duncan, R. A., Viveros, M., \& Polito, V. S. (2001). Almond flower development:floral initiation and organogenesis. Journal of American Society of Horticultural Sciences, 126(6), 689-696.

Lampinen, B., Gradziel, T. M., Yeager, J. T., Thorpe, M. A., \& Micke, W. C. (2002). Harvest maturity of almond cultivars in California's Sacramento Valley. Acta Horticulturae, 591, 457-464.

Lang, G. A., Eary, J. D., Martin, G. C., \& Darnell, R. L. (1987). Endo-, para-, and ecodormancy: physiological terminology and classification for dormancy research. HortScience, 22, 371-377.

Larcher, W. (2005). Climatic constraints drive the evolution of low temperature resistence in woody plants. Journal of Agricultural Meteorology, 61(4), 189-202.

Legave, J. M. (1978). Quelques aspects de necroses florales avant la foraison chez l'abricotier. Pomology Francaise, 17(9), 150-168.

Linsley-Noakes, G., Lou, M., \& Allan, P. (1995). Estimating daily positive Utah chill units using daily maximum and minimum temperatures. Journal of the South African Society of Horticultural Sciences, 5, 19-22.

Luedeling, E., \& Brown, P. H. (2011). A global analysis of the comparability of winter chill models for fruit and nut trees. International Journal of Biometeorology, 55, 411-421.

Luedeling, E., Zhang, M., Luedeling, V., \& Givetz, E. H. (2009). Sensitivity of winter chill models for fruit and nut trees to climatic changes expected in California's Central Valley. Agriculture, Ecosystems and Environment, 133, 23-31.

Martínez-Gómez, P., G.O., S., Sánchez-Pérez, R., R., M., \& Gradziel, T. M. (2003). New approaches to Prunus tree crop breeding. Food, Agriculture and Environment, $1(1), 52-63$.

Martinez-Gomez, P., Sanchez-Perez, R., Vaknin, Y., Dicenta, F., \& Gradziel, T. M. (2005). Improved technique for counting chromosomes in almond. Scientia Horticulturae, 105, 139-143.

Matthews, W. A., Gabrielyan, G., \& Sumner, D. A. (2008). California International Agricultural Exports in 2008 AIC Issues Brief(Vol. 36, pp. 1-9): University of California.

Moulton, K. S. (1996). Marketing. In W. C. Micke (Ed.), Almond Production Manual (pp. 3-8): UC ANR.

Murua, J.R. (1994). Yield model for Spanish almonds. Acta Horticulturae, 373, 325-332. 
NASS. (2010). 2010 California Almond Acreage Report. Sacramento USDA National Agricultural Statistical Service.

NASS. (2011). 2011 California Almond Forecast. Sacramento: USDA National Agricultural Statistics Service.

Nava, G. A., Dalmago, G., Bergamachsi, H., Paniz, R., Pires dos Santos, R., \& Marodin, G. (2009). Effect of high temperatures in the pre-blooming and blooming periods on ovule formation, pollen grains and yield of 'Granada' peach. Scientia Horticulturae, 122, 37-44.

Nieddu, G., Giunta, F., \& Mulas., M. (1990). Influence of postdormant temperatures on bloom time of four almond cultivars. Scientia Horticulturae, 43, 63-67.

Nooden, L. D., \& Weber, J. A. (1978). Environmental and hormonal control of dormancy in terminal buds of plants. In M. E. Cutter (Ed.), Dormancy and Developmental Arrest. New York: Academic Press.

Opik, H., \& Rolfe, S. (2005a). The Physiology of Flowering Plants (4th ed.). Cambridge: University Press.

Opik, H., \& Rolfe, S. (2005b). The Physiology of Flowering Plants (4th ed.). Cambridge: University Press.

Ortega, E., Dicenta, F., \& Egea, J. (2007). Rain effect on pollen-stigma adhesion and fertilization in almond. Scientia Horticulturae, 112, 345-348.

Perez, A., \& Pollack, S. (2005) Commodity Highlight: Almonds. Vol. 316. Fruit and Tree Nuts Outlook (pp. 19-25): United States Department of Agriculture ERS.

Pimenta, E., \& Polito, V. S. (1982). Embryo Sac Development in Almond [Prunus dulcis (Mill.) D. A. Webb] as Affected by Cross-, Self- and Non-pollination. Annals of Botany, 51(4), 469-479.

Polito, V. S. (2009). Dormancy and flowering in tree-crop species: UC Davis Plant Sciences.

Polito, V. S., Micke, W. C., \& Kester, D. E. (1996). Bud development, pollination and fertilization. In W. C. Micke (Ed.), Almond Production Manual (pp. 98-102): UC ANR.

Powell, L. E. (1987). Hormonal aspects of bud and seed dormancy in temperate-zone woody plants. HortScience, 22(845-850).

Proebsting, E. L. (1963). The role of air temperatures and bud development in determining hardiness of dormant Elberta peach fruit buds. Proceedings for the American Society of Horticultural Sciences, 83, 259-269.

Proebsting, E. L., \& Mills, H. H. (1961). Loss of hardiness by peach fruit buds as related to their morphological development during the pre-bloom and bloom period. Proceedings for the American Society of Horticultural Sciences, 78, 104-110.

Proebsting, E. L., \& Mills, H. H. (1978). Low temperature resistance of developing flower buds of six deciduous species. Journal of American Society of Horticultural Sciences, 103, 192-198.

Rattigan, K., \& Hill, S. J. (1986). Relationship between temperature and flowering in almond. Australian Journal of Experimental Agriculture, 26, 399-404.

Rattigan, K., \& Hill, S. J. (1987). Relationship between temperature and flowering in almond: Effect of location. Australian Journal of Experimental Agriculture, 27, 905-908. 
Reil, W., Labavitch, J. M., \& Holmberg, D. (1996). Harvesting. In W. C. Micke (Ed.), Almond Production Manual (pp. 260-264): UC ANR.

Reil, W., \& Sutter, E. (1996). Propagation. In W. C. Micke (Ed.), Almond Production Manual (pp. 64-69).

Richardson, E. A., Seeley, S. D., \& Walker, D. R. (1974). A model for estimating the completion of rest for Redhaven and Elberta peach trees. HortScience, 82, 302306.

Richardson, E. A., Seely, S. D., Walker., D. R., Anderson, J. M., \& Ashcroft, G. L. (1975). Pheno-climatography of spring peach bud development. HortScience, 10(3), 236-237.

Rieger, M. (2006). Introduction to fruit crops: Psychology Press.

Rinne, P., Tuominen, H., \& Junttila, O. (1993). Seasonal changes in bud dormancy in relation to bud morphology, water and starch content, and abscisic acid concentration in adult trees of Betula pubescens. Tree Physiology, 14, 549-561.

Rodrigo, J. (2000). Review: Spring frosts in deciduous fruit trees- morphological damage and flower hardiness. Scientia Horticulturae, 85, 155-173.

Rodrigo, J., \& Herrero, M. (2002). Effects of pre-blossom temperatures on flower development and fruit set in apricot. Scientia Horticulturae, 92, 125-135.

Roltsch, W. J., Zalom, F. G., Stawn., A. J., Strand, J. F., \& Pitcairn, M. J. (1999). Evaluation of several degree-day estimation methods in California Climates. International Journal of Biometeorology, 42(169-176).

Ruiz, D., Campoy, J., \& Egea, J. (2008). Chilling and heat requirements of apricot cultivars for flowering. Environmental and Experimental Botany, 61, 254-263.

Ruml, M., Vukovic, A., \& Milatovic, D. (2010). Evaluation of different methods for determining growing degree-day thresholds in apricot cultivars. International Journal of Biometeorology, 54, 411-422.

Russelle, M. P., Olson, R. A., Wilhelm, W., \& Power, J. F. (1984) Growth Analysis Based on Degree Days. Vol. 24. Lincoln, Nebraska.

Sanzol, J., \& Herrero, M. (2001). The effective pollination period in fruit trees. Scientia Horticulturae, 90(1-2), 1-17.

Sedgley, M., \& Griffin, A. R. (1989). Sexual Reproduction of Tree Crops. London.

Shivanna, K. R., \& Heslop-Harrison, J. (1981). Membrane state and pollen viability. Annales Botanici Fennici, 47, 759-770.

Silva, C., Garcia-Mas, J., Sanchez-Perez, A. M., Arus, P., \& Oliveira, M. (2005). Looking into flowering time in almond (Prunus dulcis Mill.) D.A. Webb):the candidate gene approach. Theoretical Applied Genetics, 110(5), 959-968.

Snyder, R. L. (1985). Hand calculating degree days. Agriculture and Forest Meteorology, 35, 353-358.

Snyder, R. L., Spano, D., Cesaraccio, C., \& Duce, P. (1999). Determining degree-day thresholds from field observations. International Journal of Biometeorology, 42, 117-182.

Socias i Company, R. (1997). Qualitative traits in almond NucisNewsletter (Vol. 6, pp. 69): Network on Nuts FAO-CIHEAM.

Socias i Company, R., Kester, D., \& Bradley, M. (1976). Effects of temperature and genotype on pollen tube growth of some self-compatible and self-incompatible 
almond cultivars. Journal of American Society of Horticultural Sciences, 101(5), 490-493.

Somerville, W. (1996). Pruning and training fruit trees: Elsevier.

Suttle, J. C., \& Hulstrand, J. F. (1994). Role of endogenous abscisic acid in potato microtuber dormancy. Plant Physiology, 105, 891-896.

Tabuenca, M. (1972). Necesidades de frio invernal en almendro. . An. Estac. Exp. Aula Dei, 11, 325-329.

Taiz, L., \& Zeiger, E. (2010). Plant Physiology (5th ed.): Sinauer Associates.

Thomson, J. D., \& Goodell, K. (2002). Pollen removal and deposition by honeybee and bumblebee visitors to apple and almond flowers. Journal of Applied Ecology, 38(5), 1032-1044.

Thorp, R. W. (1996). Bee management for pollination. In W. C. Micke (Ed.), Almond Production Manual (pp. 132-154): UC ANR.

Tombesi, S., Scalia, R., J.Connell, Lampinen, B., \& DeJong, T. M. (2010). Fruit development in almond is influenced by early spring temperatures in California. Journal of Horticultural Science and Biotechnology, 85(4), 317-322.

Tromp, J. (1986). The effect of four early spring temperature regimes on apple fruit set, tree growth and the $\mathrm{K}$ and $\mathrm{Ca}$ level in fruits. Scientia Horticulturae, 30, 109-116.

vanEngelsdorp, D., Foster-Cox, D., Frazier, M., Ostiguy, N., \& Hayes, J. (Producer). (2006, May 20, 2011). Fall Dwindle Disease: Investigations into the Causes of Sudden and Alarming Colony Losses Experienced by Beekeepers in the Fall of 2006. Apiary Section. [published interview]

Vargas, F. J., \& Romero, M. A. (2001). Blooming time in almond progenies. Paper presented at the 11th GREMPA Seminar on pistachios and almonds. , Blooming time in almond progenies.

Viti, R., \& Monteleone, P. (1991). Observations on flower bud growth in some low yield varieties of apricot. Acta Horticulturae, 293, 319-326.

Viveros, M. (2002, February 14, 2002). Almond tree planting, Deciduous Tree Fruits and Nuts.

Weinbaum, S. A., Parfitt, D. E., \& Polito, V. S. (1984). Differential cold sensitivity of pollen grain fermination in two Prunus species. Euphytica, 33, 419-426.

Weinbaum, S. A., Polito, V. S., \& Muraoka, T. T. (1989). Assessment of rest completion and its relationship to appearance of tetrads in anthers of "Nonpareil" almond.

Scientia Horticulturae, 38(1-2), 69-76.

Weinberger, J. H. (1950). Chilling requirements of peach varieties. Proc. Am. Soc. Hort. Sci., 56, 122-128.

Weiser, C. J. (1970). Cold resistance and injury in woody plants. Science, 169, 12691278.

WesternFarmPress. (2010). California's almond acreage tops 800,000 acres, Western Farm Press.

Williams, R. R. (1970). Factors affecting pollination in fruit trees. In L. C. Luckwill \& C. V. Cutting (Eds.), Physiology of Tree Crops (pp. 193-207). London: Academic Press.

Wilson, L. T., \& Barnett, W. W. (1983). Degree-days: an aid in crop and pest management. California Agriculture, 37(1-2), 4-7. 
Wood, M. N. (1925). Almond varieties in the United States. In USDA (Ed.), (Vol. 1282, pp. 1-42): USDA.

Yi, W., Law, S. E., Mccoy, D., \& Wetzstein, H. Y. (2006). Stigma development and receptivity in almond (Prunus dulcis). Annals of Botany, 97, 57-63.

Zalom, F. G., Goodell, P. B., Wilson, L. T., Barnett, W. W., \& Bentley, W. J. (1983). Degree-days: the calculation and use of heat units in pest management. In U. o. California (Ed.), Division of Agriculture and Natural Resources (Vol. Leaflet 21373, pp. 1-10). Berkeley, CA.

Zohary, D., \& Hopf, M. (1993). Domestication of plants in the old world: the origin and spread of cultivated plants in West Asia, Europe, and the Nile Valley. (Second ed.). New York: University Press. 


\section{APPENDICES}

\section{A. Butte County RAVT Bloom Data for 1996 (top) and 2006 (bottom)}
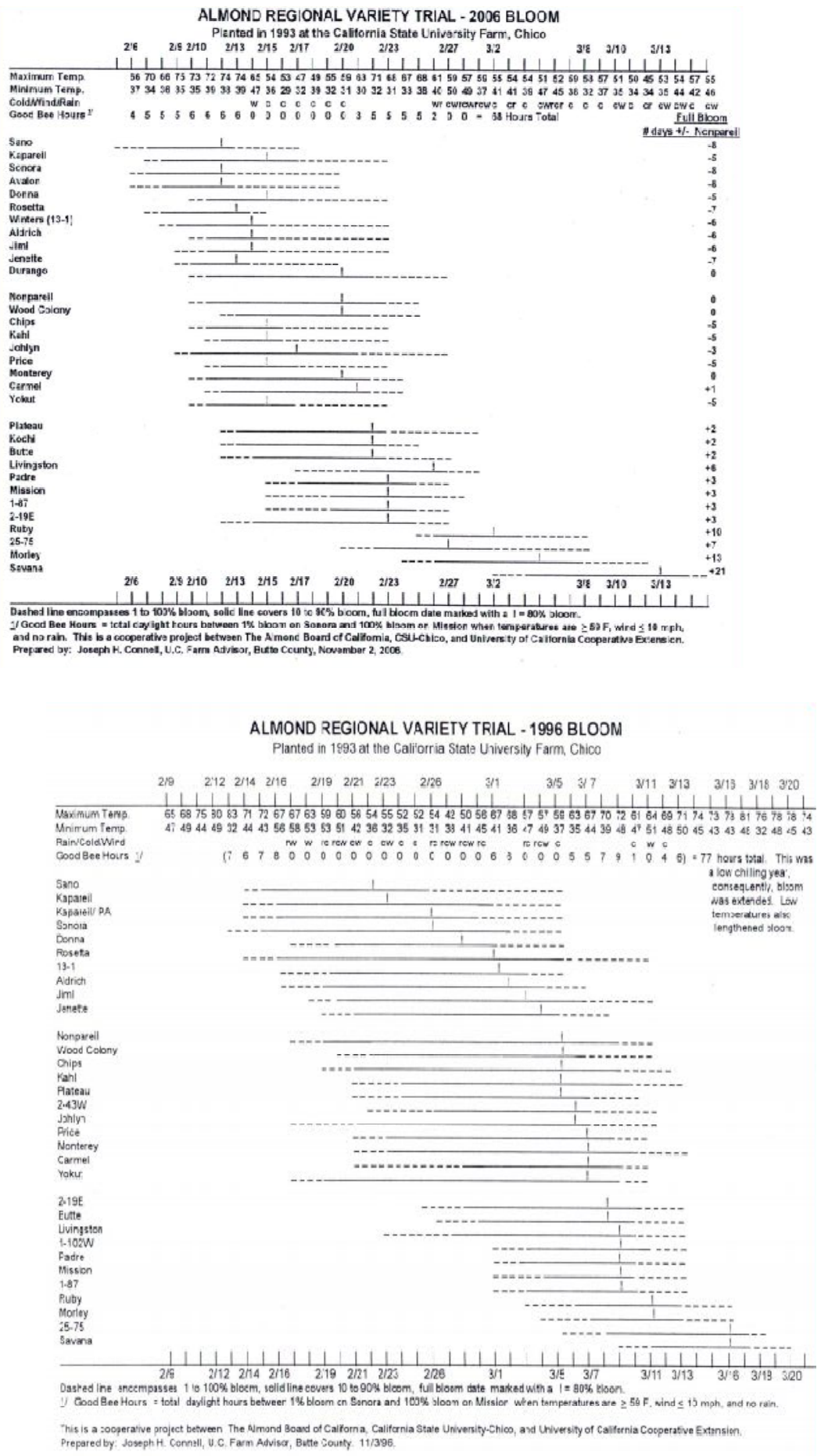


\section{B. San Joaquin County RAVT Bloom Data for 1996 (top) and 2006 (bottom}

MANTECA ALMOND REGIONAL VARIETY TRIAL

1996 BLOOM

S.J. DELTA COLLEGE

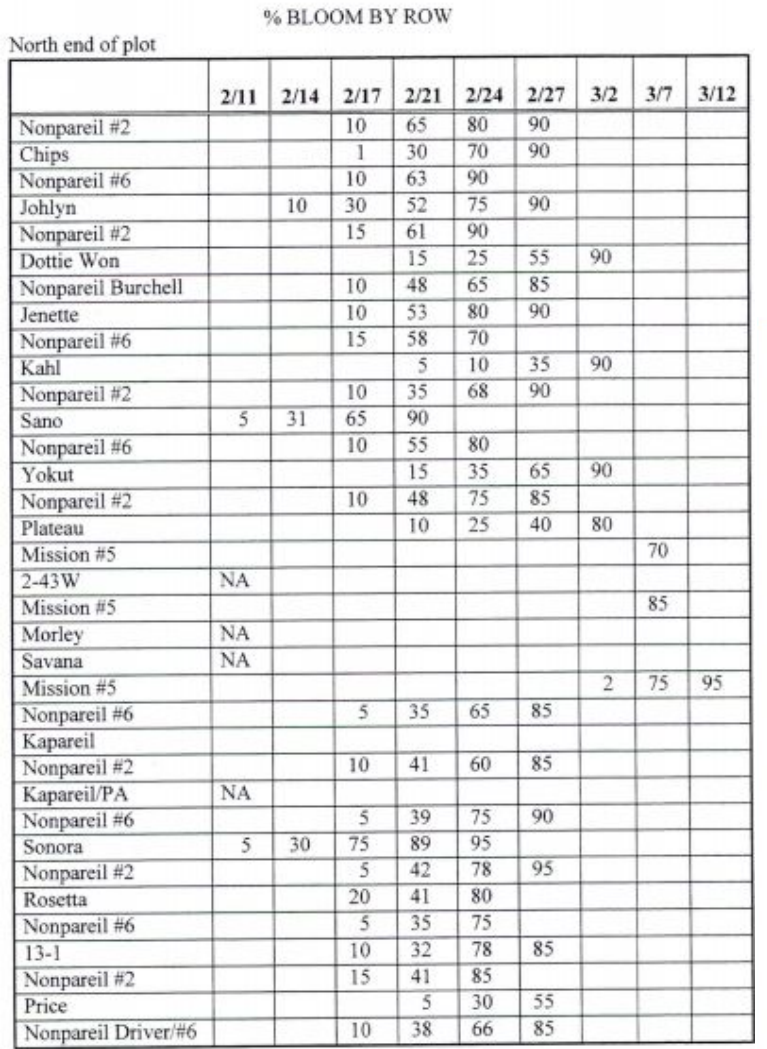

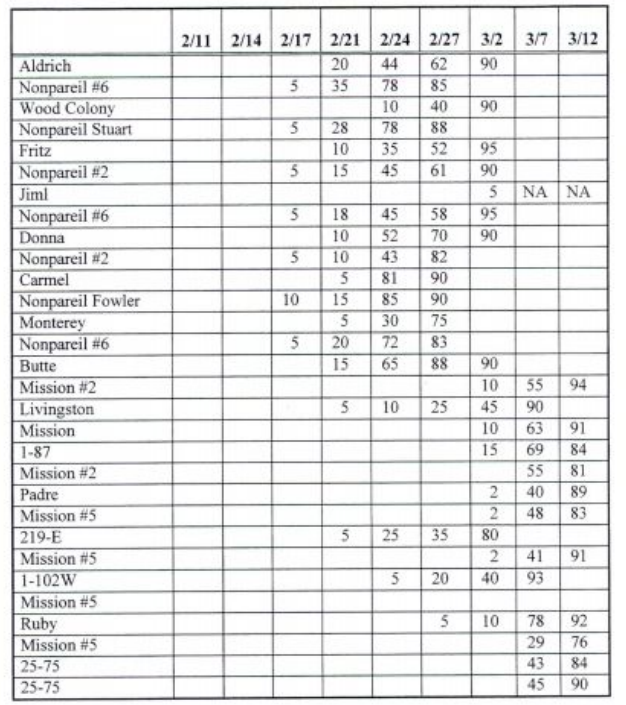

SAN JOAQUIN DELTA COLLEGE ALMOND REGIONAL VARIETY TRIAL

2006 Bloom Dates

Manteca

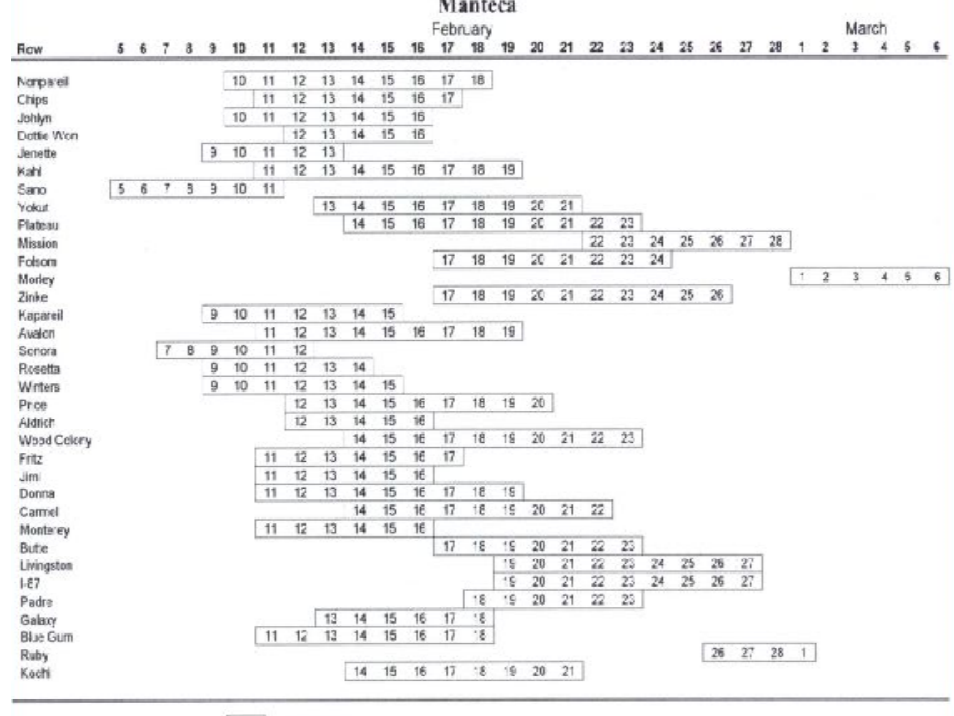

$\square=10$ TOSOS 


\section{Kern County RAVT Bloom Data for 1996}

\section{EFFECTIVE BLOOM PERIOD}

Kern RVT - Paramount Farming Company

1996

\begin{tabular}{||l|c|c|c||}
\hline \multirow{2}{*}{ Farly Blooming Varieties } \\
\cline { 2 - 4 } & Beginning & Full & End \\
\cline { 2 - 4 } & $2-08$ & $2-15$ & $2-19$ \\
\hline Sano & $2-12$ & $2-15$ & $2-20$ \\
\hline Kapareil & $2-12$ & $2-16$ & $2-21$ \\
\hline Rosetta & $2-13$ & $2-19$ & $2-25$ \\
\hline Sonora & $2-13$ & $2-20$ & $2-24$ \\
\hline $13-1$ & \multicolumn{3}{|c||}{} \\
\hline
\end{tabular}

\begin{tabular}{||l|c|c|c||}
\hline \multirow{2}{*}{ Mid-Season Blooming Varieties } \\
\cline { 2 - 4 } & \multicolumn{3}{|c||}{ Bloom Period } \\
\hline Nonpareil & $2-15$ & $2-19$ & End \\
\hline Price & $2-15$ & $2-18$ & $2-22$ \\
\hline Jenette & $2-15$ & $2-20$ & $2-29$ \\
\hline Yokut & $2-15$ & $2-19$ & $2-29$ \\
\hline Johlyn & $2-15$ & $2-19$ & $2-22$ \\
\hline Plateau & $2-16$ & $2-19$ & $2-22$ \\
\hline Chips & $2-16$ & $2-19$ & $2-21$ \\
\hline Kahl & $2-16$ & $2-19$ & $2-21$ \\
\hline Fritz & $2-17$ & $2-22$ & $2-26$ \\
\hline Monterey & $2-17$ & $2-22$ & $3-1$ \\
\hline Aldrich & $2-18$ & $2-22$ & $2-26$ \\
\hline Wood Colony & $2-18$ & $2-23$ & $3-2$ \\
\hline $1-102 W$ & $2-18$ & $2-22$ & $3-7$ \\
\hline Jiml & $2-18$ & $2-22$ & $3-1$ \\
\hline Donna & $2-18$ & $2-18$ & $2-22$ \\
\hline Carmel & $2-18$ & $2-29$ & $3-3$ \\
\hline $2-19 E$ & $2-18$ & $2-22$ & $3-1$ \\
\hline $2-43$ W & $2-18$ & $2-22$ & $3-3$ \\
\hline \hline L & & & \\
\hline
\end{tabular}

\begin{tabular}{||l|c|c|c||}
\hline \multirow{2}{*}{ Late Season Blooming Varieties } \\
\cline { 2 - 4 } & Beginning & Full & End \\
\hline \multirow{2yyy}{*}{ Butte } & $2-19$ & $3-1$ & $3-8$ \\
\hline Livingston & $2-19$ & $3-1$ & $3-9$ \\
\hline Padre & $2-19$ & $3-7$ & $3-4$ \\
\hline $1-87$ & $2-20$ & $3-2$ & $3-9$ \\
\hline $25-75$ & $2-22$ & $3-2$ & $3-10$ \\
\hline Mission & $2-24$ & $3-2$ & $3-9$ \\
\hline Ruby & $2-27$ & $3-3$ & $3-6$ \\
\hline Morley & $2-28$ & $3-3$ & $3-11$ \\
\hline Savana & $2-29$ & $3-11$ & $3-17$ \\
\hline
\end{tabular}

Bloom Observations

Good Blooming Varieties: Nonpareil, Chips, Jenette, Sano, Sonora, Rosetta, Aldrich, Donna, Carmel, Monterey, Mission, Ruby, Padre and Butte

Average Blooming Varieties: Wood Colony, Livingston, 1-87 and 2-19E

Poor Blooming Varieties: Johlyn, Kahl, Yokut, Morley, Kapareil, 13-1, Price, Fritz, Jiml, $1-102 \mathrm{~W}$ and $25-75$

Chilling Hours: 336 hours below $45^{\circ} \mathrm{F}$ 


\section{Kern County RAVT Bloom Data for 2006}

\begin{tabular}{|c|c|c|c|}
\hline \multicolumn{4}{|c|}{ Early Blooming Varieties } \\
\hline & \multicolumn{3}{|c|}{ Bloom Period } \\
\hline & Beginning & Full & End \\
\hline Sano & $01-25-06$ & $02-10-06$ & $02-21-06$ \\
\hline Kapareil & $01-22-06$ & $02-10-06$ & $02-25-06$ \\
\hline Rosetta & $01-27-06$ & $02-17-06$ & $02-26-06$ \\
\hline Sonora & $02-02-06$ & $02-17-06$ & $02-25-06$ \\
\hline (Winters) (13-1) & $01-22-06$ & $02-14-06$ & $02-25-06$ \\
\hline \multicolumn{4}{|c|}{ Mid-Season Blooming Varieties } \\
\hline & \multicolumn{3}{|c|}{ Bloom Period } \\
\hline & Beginning & Full & End \\
\hline Nonpareil & $02-08-06$ & $02-17-06$ & 03-03-06 \\
\hline Price & $02-02-06$ & $02-17-06$ & $02-24-06$ \\
\hline Jenette & $02-02-06$ & $02-17-06$ & $02-25-06$ \\
\hline Yokut & $02-08-06$ & $02-17-06$ & $02-26-06$ \\
\hline Johlyn & $01-27-06$ & $02-17-06$ & $03-06-06$ \\
\hline Plateau & $02-10-06$ & $02-21-06$ & $02-25-06$ \\
\hline Chips & $01-31-06$ & $02-17-06$ & $02-26-06$ \\
\hline Kahl & $02-08-06$ & $02-17-06$ & $02-25-06$ \\
\hline Fritz & $02-08-06$ & $02-17-06$ & $02-25-06$ \\
\hline Monterey & $02-10-06$ & $02-21-06$ & $02-27-06$ \\
\hline Aldrich & $02-10-06$ & $02-21-06$ & $03-01-06$ \\
\hline Wood Colony & $02-10-06$ & $02-21-06$ & $03-03-06$ \\
\hline $1-102 \mathrm{~W}$ & $02-14-06$ & $02-27-06$ & $03-05-06$ \\
\hline Jim 1 & $02-10-06$ & $02-27-06$ & $03-03-06$ \\
\hline Donna & $02-08-06$ & $02-17-06$ & $02-26-06$ \\
\hline Carmel & $02-10-06$ & $02-21-06$ & 03-05-06 \\
\hline $2-19 \mathrm{E}$ & $02-12-06$ & $02-21-06$ & 03-09-06 \\
\hline $2-43 W$ & $02-10-06$ & $02-24-06$ & 03-09-06 \\
\hline
\end{tabular}

EFFECTIVE BLOOM PERIOD

Kern RVT - Paramount Farming Company

(continued)

\begin{tabular}{|l|c|c|c||}
\hline \multicolumn{3}{|c|}{ Late Season Blooming Varieties } \\
\hline & \multicolumn{3}{|c||}{ Bloom Period } \\
\cline { 2 - 4 } & Beginning & Full & End \\
\hline Livingston & $02-14-06$ & $02-27-06$ & $03-05-06$ \\
\hline Padre & $02-14-06$ & $02-27-06$ & $03-08-06$ \\
\hline $1-87$ & $02-14-06$ & $02-27-06$ & $03-05-06$ \\
\hline $25-75$ & $02-17-06$ & $02-27-06$ & $03-08-06$ \\
\hline Mission & $02-17-06$ & $02-27-06$ & $03-08-06$ \\
\hline Ruby & $02-24-06$ & $02-27-06$ & $03-07-06$ \\
\hline Morley & $02-21-06$ & $02-27-06$ & $03-01-06$ \\
\hline Savana & $02-27-06$ & $03-15-06$ & $03-19-06$ \\
\hline \hline
\end{tabular}

Bloom Observations:

Chilling Hours: The following table shows the number of chilling hours for November, December and Januarv 15 for 2001-2002 to 2005-2006. 


\section{E. Almond Bud Development Stages}

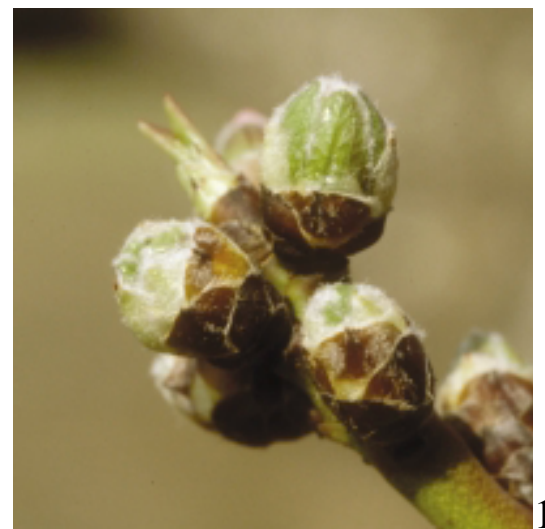

1. Green Tip
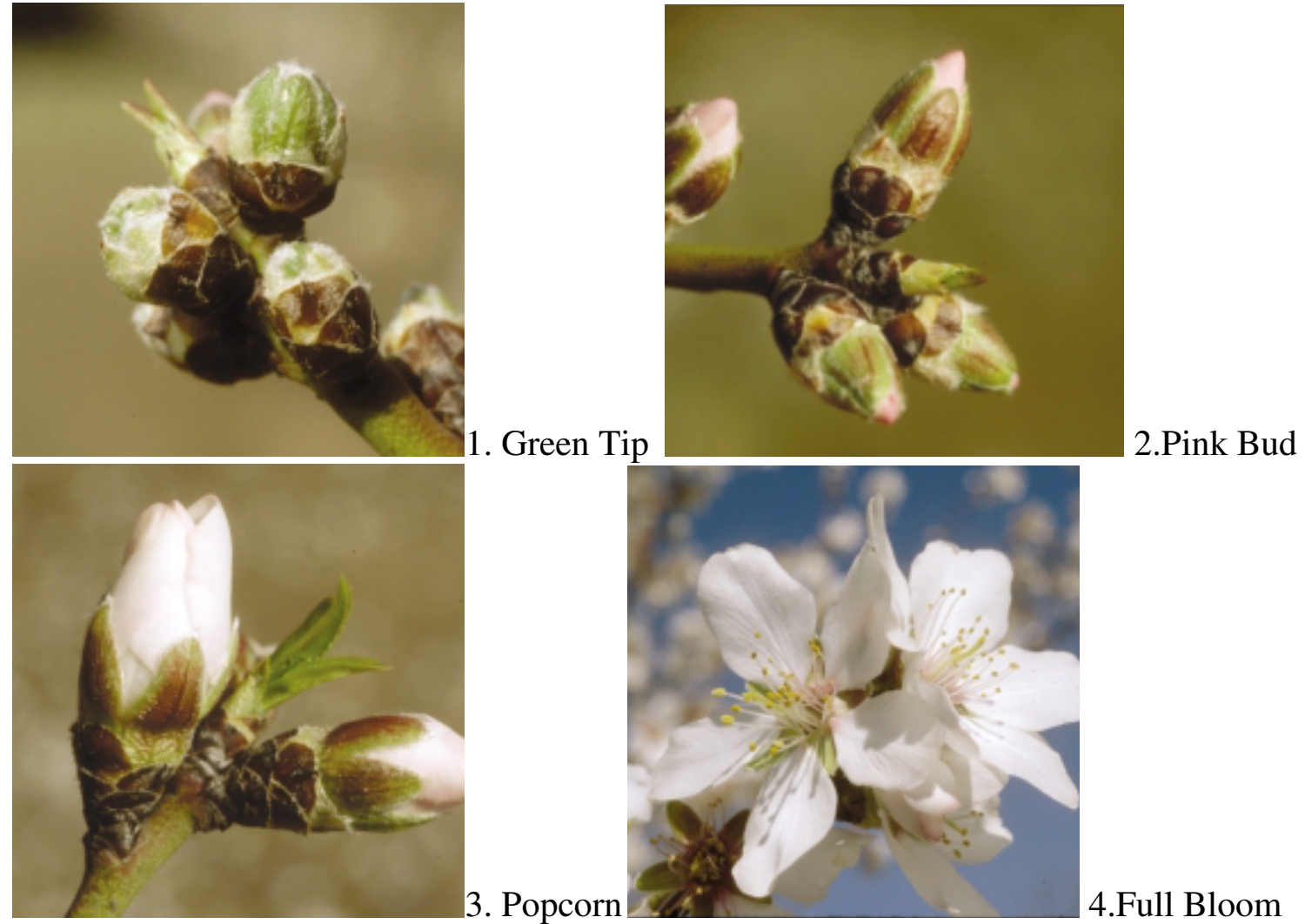

3. Popcorn
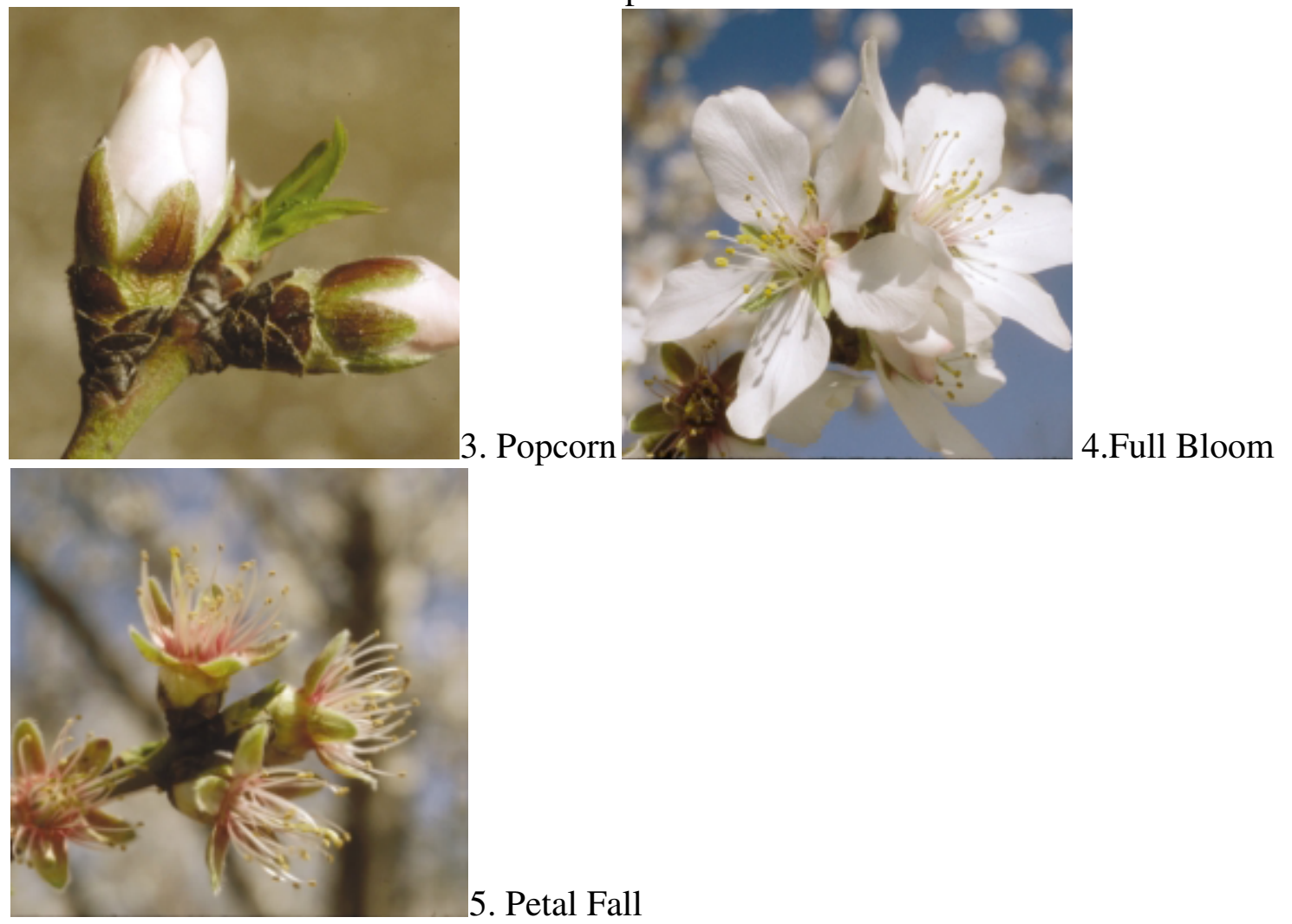


\section{F. Dynamic Model Calculation File which is available for download through the UC Davis Fruit and Nut Center website.}

\begin{tabular}{|c|c|c|c|c|c|c|c|c|c|c|c|c|}
\hline & & $\mathrm{e} 0$ & $4.15 \mathrm{E}+03$ & & & & & & & & & \\
\hline & & e1 & $1.29 \mathrm{E}+04$ & & \multicolumn{6}{|c|}{ DYNAMIC MODEL CHILLING PORTIONS - EREZ, A. and FISHMAN, S. } & & \\
\hline & & $\mathrm{a} 0$ & $1.40 \mathrm{E}+05$ & & & \multicolumn{5}{|c|}{ The Volcani Center, Bet Dagan, ISRAEL } & & \\
\hline & & $\mathrm{a} 1$ & $2.57 \mathrm{E}+18$ & & & & & & & & & \\
\hline & & slp & 1.6 & & \multicolumn{6}{|c|}{ Add hourly data in column B from row 13 down.Do not erase rows 11, 12.} & & \\
\hline & & tetmlt & 277 & & \multicolumn{5}{|c|}{ copy data from row 12 colums $\mathrm{C}$ to $\mathrm{L}$ till the last entry in column $\mathrm{B}$. } & & & \\
\hline & & $\mathrm{aa}=\mathrm{a} 0 / \mathrm{a} 1$ & $5.43 \mathrm{E}-14$ & & \multicolumn{4}{|c|}{ total cumulative chiling portions will appear in column L. } & & & & \\
\hline & & $\mathrm{ee}=\mathrm{e} 1-\mathrm{e} 0$ & $8.74 \mathrm{E}+03$ & & & & & & & & & \\
\hline & date & Temp(C) & Temp (K) & ftmprt & $\mathrm{sr}$ & $x i$ & $\mathrm{xs}$ & ak1 & Inter-S & Inter-E & delt & Portions \\
\hline & 12/4/1999 16:45 & 15 & 288.00 & 16.93 & 22471935.51 & 1.00 & 0.81 & 0.09 & 0.00 & 0.07 & 0.00 & $\overline{0}$ \\
\hline & 12/4/1999 17:45 & 12 & 285.00 & 12.44 & 252887.94 & 1.00 & 1.11 & 0.06 & 0.07260431 & 0.13 & 0.00 & 0 \\
\hline $10 / 1 / 2008$ & 100 & 14.7 & 287.70 & 16.48 & 14407813.13 & 1.00 & 0.83 & 0.09 & 0.13193829 & 0.19 & 0.00 & 0 \\
\hline $10 / 1 / 2008$ & 200 & 13.8 & 286.80 & 15.14 & 3776136.65 & 1.00 & 0.92 & 0.08 & 0.19227851 & 0.25 & 0.00 & 0 \\
\hline $10 / 1 / 2008$ & 300 & 13.1 & 286.10 & 14.10 & 1324955.19 & 1.00 & 0.99 & 0.07 & 0.24674292 & 0.30 & 0.00 & 0 \\
\hline $10 / 1 / 2008$ & 400 & 12.3 & 285.30 & 12.89 & 397780.57 & 1.00 & 1.08 & 0.06 & 0.29684991 & 0.34 & 0.00 & 0 \\
\hline $10 / 1 / 2008$ & 500 & 12.6 & 285.60 & 13.35 & 625094.59 & 1.00 & 1.04 & 0.06 & 0.34347991 & 0.39 & 0.00 & 0 \\
\hline $10 / 1 / 2008$ & 600 & 12.9 & 285.90 & 13.80 & 981377.17 & 1.00 & 1.01 & 0.07 & 0.38725372 & 0.43 & 0.00 & 0 \\
\hline $10 / 1 / 2008$ & 700 & 12.5 & 285.50 & 13.20 & 537721.65 & 1.00 & 1.05 & 0.06 & 0.42805479 & 0.47 & 0.00 & 0 \\
\hline $10 / 1 / 2008$ & 800 & 18 & 291.00 & 21.32 & 1820426715.75 & 1.00 & 0.59 & 0.15 & 0.4666457 & 0.48 & 0.00 & 0 \\
\hline $10 / 1 / 2008$ & 900 & 22.1 & 295.10 & 27.18 & 639360520682.31 & 1.00 & 0.39 & 0.28 & 0.48394444 & 0.46 & 0.00 & 0 \\
\hline $10 / 1 / 2008$ & 1000 & 24.5 & 297.50 & 30.54 & 18334981945924.40 & 1.00 & 0.31 & 0.39 & 0.46120998 & 0.41 & 0.00 & 0 \\
\hline $10 / 1 / 2008$ & 1100 & 27.8 & 300.80 & 35.07 & 1695953096607430.00 & 1.00 & 0.22 & 0.63 & 0.41109703 & 0.32 & 0.00 & 0 \\
\hline $10 / 1 / 2008$ & 1200 & 29.7 & 302.70 & 37.63 & 21977759389044300.00 & 1.00 & 0.19 & 0.83 & 0.32272037 & 0.25 & 0.00 & 0 \\
\hline $10 / 1 / 2008$ & 1300 & 31.3 & 304.30 & 39.76 & 185399287025163000.00 & 1.00 & 0.16 & 1.03 & 0.24544222 & 0.19 & 0.00 & 0 \\
\hline $10 / 1 / 2008$ & 1400 & 32.9 & 305.90 & 41.87 & 1529482721869290000.00 & 1.00 & 0.14 & 1.29 & 0.18989423 & 0.15 & 0.00 & 0 \\
\hline $10 / 1 / 2008$ & 1500 & 32.5 & 305.50 & 41.35 & 904347586761999000.00 & 1.00 & 0.14 & 1.22 & 0.15158765 & 0.15 & 0.00 & 0 \\
\hline $10 / 1 / 2008$ & 1600 & 31.1 & 304.10 & 39.50 & 142192089006867000.00 & 1.00 & 0.16 & 1.01 & 0.14501999 & 0.16 & 0.00 & 0 \\
\hline $10 / 1 / 2008$ & 1700 & 28.9 & 301.90 & 36.55 & 7503085707671290.00 & 1.00 & 0.20 & 0.74 & 0.15597499 & 0.18 & 0.00 & 0 \\
\hline $10 / 1 / 2008$ & 1800 & 26.9 & 299.90 & 33.84 & 498295340987133.00 & 1.00 & 0.24 & 0.56 & 0.17900757 & 0.21 & 0.00 & 0 \\
\hline $10 / 1 / 2008$ & 1900 & 24.8 & 297.80 & 30.96 & 27785644859427.80 & 1.00 & 0.30 & 0.41 & 0.20614258 & 0.24 & 0.00 & 0 \\
\hline $10 / 1 / 2008$ & 2000 & 23.2 & 296.20 & 28.73 & 2997191580972.99 & 1.00 & 0.35 & 0.32 & 0.23705772 & 0.27 & 0.00 & 0 \\
\hline $10 / 1 / 2008$ & 2100 & 20.6 & 293.60 & 25.06 & 76328377542.66 & 1.00 & 0.45 & 0.22 & 0.26814589 & 0.30 & 0.00 & 0 \\
\hline 10/1/2008 & 2200 & 19.8 & 292.80 & 23.92 & 24351200680.88 & 1.00 & 0.49 & 0.20 & 0.30486054 & 0.34 & 0.00 & 0 \\
\hline $10 / 1 / 2008$ & 2300 & 19.6 & 292.60 & 23.63 & 18283319082.78 & 1.00 & 0.50 & 0.19 & 0.33811896 & 0.37 & 0.00 & 0 \\
\hline $10 / 1 / 2008$ & 2400 & 18.8 & 291.80 & 22.48 & 5787453319.27 & 1.00 & 0.54 & 0.17 & 0.36647757 & 0.39 & 0.00 & 0 \\
\hline $10 / 2 / 2008$ & 100 & 17.4 & 290.40 & 20.45 & 761414697.69 & 1.00 & 0.63 & 0.14 & 0.39411584 & 0.42 & 0.00 & 0 \\
\hline $10 / 2 / 2008$ & 200 & 17.6 & 290.60 & 20.74 & 1018541959.74 & 1.00 & 0.62 & 0.14 & 0.42405627 & 0.45 & 0.00 & 0 \\
\hline
\end{tabular}




\section{G. Nonpareil Raw Data}

\begin{tabular}{|c|c|c|c|c|c|c|c|c|c|c|c|c|c|c|c|c|c|c|c|c|c|}
\hline 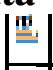 & & 墨. & 墨. & $\underline{\underline{\underline{\underline{w}}}}$ & 亚. & & & {$[\underline{\underline{\underline{x}}}$} & 吾. & $\underline{\underline{\underline{\underline{v}}}}$ & & & & & 黑 & & & & & & \\
\hline 点 & 点 & 点 & 齿 & 点 & 㤐 & 点 & & 㵄 & 悫 & 点 & 嘘 & 产 & 点 & $\vec{s}$ & & 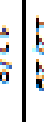 & & & & & 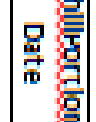 \\
\hline 心 & 它 & in & un & $\dot{\sim}$ & เ́ & 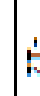 & & $\frac{1}{12}$ & $\dot{5}$ & $\mu$ & $\dot{-}$ & $\dot{E}$ & 灾 & th & in: & 1 & $\dot{\overrightarrow{\mathrm{\theta}}}$ & $\mid \dot{\vec{t}}$ & h & & \\
\hline$\leftrightarrows$ & s & t & $\pi$ & ת & $\pi$ & $r$ & & $\mathbf{t}$ & aे & 商 & 志 & 古 & 幽 & 5 & 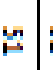 & $n$ & ב & th & & s & '. \\
\hline 궁 & 립 & 검 & 값 & 감 & 긊 & ปี & & 리 & $\overline{\mathrm{z}}$ & 괍 & : & $\because$ & ب: & 点 & 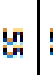 & 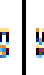 & In & ي & & $g$ & 娄 \\
\hline 侖 & 胥 & 产 & N & $\frac{\mathrm{w}}{\mathrm{N}}$ & 心్心 & 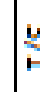 & & E & 古 & 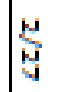 & w & 策 & $\underset{\mathrm{\omega}}{\mathrm{w}}$ & 产 & जu & 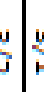 & 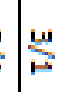 & & & & 콩 믕 \\
\hline or & 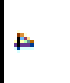 & a & + & ${ }^{\circ}$ & 4 & . & & $\mathrm{c}$ & ${ }^{\circ}$ & |̈ & E & + & or & $\checkmark$ & un, & 0 & $\infty$ & $E$ & & & \\
\hline $\mid$\begin{tabular}{|c|}
$\mathbf{m}$ \\
- \\
-
\end{tabular} & 商 & $\mathbb{N}$ & : & 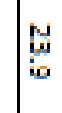 & 空 & $\breve{c}$ & & 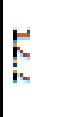 & 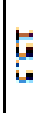 & $\mathrm{F}$ & 点 & 岕 & पू & ب & ts & $\begin{array}{c}y \\
\text { on }\end{array}$ & 晜 & . & 苟 & & \\
\hline 点 & 㤐 & 总 & 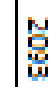 & 荘 & 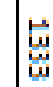 & 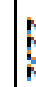 & & $\mid \frac{\mathscr{L}}{\alpha}$ & 点 & 落 & 岁 & 预 & 忿 & క. & 茶 & 5 & 㤐 & 虑 & & 夢 & 数品 \\
\hline 0 & 0 & 0 & - & - & + & ' & & c & 0 & $\mu$ & o & $\circ$ & 2 & & & o & 0 & $\mapsto$ & &. & \\
\hline
\end{tabular}

H. Nonpareil Raw Data 


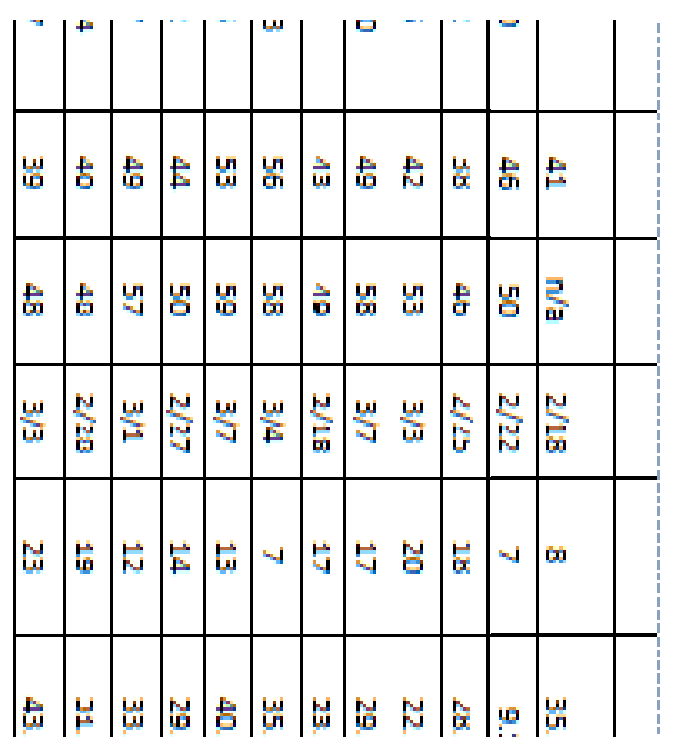




\section{Nonpareil Raw Data}

\begin{tabular}{|c|c|c|c|c|c|c|c|c|}
\hline Site & Year & Variety & $\begin{array}{c}\text { ChillPortionD } \\
\text { ate }\end{array}$ & $\begin{array}{c}\text { pred. } \mathrm{CH}_{2} \text { non } \\
\text { pareil,date }\end{array}$ & $\begin{array}{l}\text { pred.Cu,non } \\
\text { pareil,date }\end{array}$ & $\begin{array}{l}\text { pred.CP.nonp } \\
\text { areil.date }\end{array}$ & $\begin{array}{l}\text { pred.jan1.no } \\
\text { npareil.date }\end{array}$ & $\begin{array}{l}\text { pred.calenda } \\
\text { rnonpareiled } \\
\text { ate }\end{array}$ \\
\hline Butte & 1996 & Nonpareil & $1 / 7$ & $3 / 3$ & $3 / 3$ & $3 / 4$ & $2 / 17$ & $2 / 25$ \\
\hline Butte & 1997 & Nonpareil & $12 / 22$ & $3 / 5$ & $2 / 25$ & $2 / 22$ & $2 / 26$ & $2 / 25$ \\
\hline Butte & 1998 & Nonpareil & $12 / 17$ & $3 / 2$ & $3 / 3$ & $2 / 24$ & $3 / 1$ & $2 / 25$ \\
\hline Butte & 1999 & Nonpareil & $12 / 12$ & $3 / 8$ & $3 / 10$ & $3 / 4$ & $3 / 18$ & $2 / 25$ \\
\hline Butte & 2000 & Nonpareil & $12 / 29$ & $2 / 22$ & $2 / 24$ & $2 / 28$ & $2 / 24$ & $2 / 25$ \\
\hline Butte & 2001 & Nonpareil & $12 / 8$ & $2 / 22$ & $3 / 6$ & $2 / 28$ & $3 / 17$ & $2 / 25$ \\
\hline Butte & 2002 & Nonpareil & $12 / 25$ & $3 / 16$ & $3 / 1$ & $2 / 28$ & $3 / 2$ & $2 / 25$ \\
\hline Butte & 2003 & Nonpareil & $12 / 25$ & $2 / 17$ & $2 / 22$ & $2 / 22$ & $2 / 22$ & $2 / 25$ \\
\hline Butte & 2004 & Nonpareil & $12 / 16$ & $3 / 7$ & $2 / 1$ & $3 / 5$ & $3 / 13$ & $2 / 25$ \\
\hline Butte & 2005 & Nonpareil & $12 / 18$ & $2 / 27$ & $2 / 27$ & $3 / 1$ & $3 / 9$ & $2 / 25$ \\
\hline Butte & 2006 & Nonpareil & $12 / 30$ & $2 / 4$ & $2 / 14$ & $2 / 28$ & $2 / 24$ & $2 / 25$ \\
\hline Manteca & 1996 & Nonpareil & $1 / 1$ & $3 / 1$ & $3 / 3$ & $2 / 25$ & $2 / 18$ & $2 / 23$ \\
\hline Manteca & 1997 & Nonpareil & $12 / 15$ & $3 / 1$ & $3 / 3$ & $2 / 19$ & $3 / 4$ & $2 / 23$ \\
\hline Manteca & 1998 & Nonpareil & $12 / 23$ & $2 / 22$ & $3 / 3$ & $2 / 28$ & $3 / 2$ & $2 / 23$ \\
\hline Manteca & 1999 & Nonpareil & $12 / 19$ & $3 / 4$ & $3 / 15$ & $3 / 13$ & $3 / 19$ & $2 / 23$ \\
\hline Manteca & 2000 & Nonpareil & $12 / 26$ & $2 / 19$ & $2 / 22$ & $2 / 27$ & $2 / 26$ & $2 / 23$ \\
\hline Manteca & 2001 & Nonpareil & $12 / 10$ & $2 / 28$ & $3 / 6$ & $3 / 2$ & $3 / 19$ & $2 / 23$ \\
\hline Manteca & 2002 & Nonpareil & $1 / 5$ & $3 / 14$ & $3 / 3$ & $3 / 11$ & $3 / 1$ & $2 / 23$ \\
\hline Manteca & 2003 & Nonpareil & $12 / 22$ & $2 / 19$ & $2 / 20$ & $2 / 21$ & $2 / 25$ & $2 / 23$ \\
\hline Manteca & 2004 & Nonpareil & $12 / 19$ & $3 / 7$ & $3 / 2$ & $3 / 6$ & $3 / 13$ & $2 / 23$ \\
\hline Manteca & 2005 & Nonpareil & $12 / 9$ & $2 / 26$ & $2 / 27$ & $2 / 23$ & $3 / 14$ & $2 / 23$ \\
\hline Manteca & 2006 & Nonpareil & $1 / 3$ & $3 / 2$ & $2 / 21$ & $3 / 5$ & $2 / 24$ & $2 / 23$ \\
\hline Kern & 1996 & Nonpareil & $1 / 10$ & $3 / 10$ & $3 / 9$ & $3 / 9$ & $2 / 28$ & $2 / 28$ \\
\hline Kern & 1997 & Nonpareil & $12 / 29$ & $3 / 1$ & $3 / 8$ & $3 / 2$ & $3 / 3$ & $2 / 28$ \\
\hline Kern & 1998 & Nonpareil & $12 / 25$ & $3 / 8$ & $3 / 12$ & $3 / 3$ & $3 / 8$ & $2 / 28$ \\
\hline Kern & 1999 & Nonpareil & $12 / 21$ & $3 / 16$ & $3 / 16$ & $3 / 17$ & $3 / 26$ & $2 / 28$ \\
\hline
\end{tabular}




\section{J. Nonpareil Raw Data}

\begin{tabular}{|l|l|l|l|c|c|c|c|c|}
\hline Kern & 2000 & Nonpareil & $1 / 2$ & $2 / 28$ & $3 / 5$ & $3 / 5$ & $3 / 2$ & $2 / 28$ \\
\hline Kern & 2001 & Nonpareil & $12 / 18$ & $3 / 7$ & $3 / 11$ & $3 / 11$ & $3 / 22$ & $2 / 28$ \\
\hline Kern & 2002 & Nonpareil & $12 / 26$ & $3 / 7$ & $3 / 10$ & $3 / 4$ & $3 / 8$ & $2 / 28$ \\
\hline Kern & 2003 & Nonpareil & $12 / 29$ & $3 / 2$ & $2 / 27$ & $3 / 2$ & $3 / 3$ & $2 / 28$ \\
\hline Kern & 2004 & Nonpareil & $12 / 24$ & $3 / 12$ & $3 / 9$ & $3 / 10$ & $3 / 17$ & $2 / 28$ \\
\hline Kern & 2005 & Nonpareil & $12 / 17$ & $3 / 8$ & $3 / 6$ & $3 / 4$ & $3 / 17$ & $2 / 28$ \\
\hline Kern & 2006 & Nonpareil & $1 / 17$ & $3 / 14$ & $2 / 27$ & $3 / 25$ & $3 / 7$ & $2 / 28$ \\
\hline
\end{tabular}




\section{K. Nonpareil Raw Data}

\begin{tabular}{|c|c|c|c|c|c|c|}
\hline Site & Year & Variety & GDH.ChilltoBloom90.CH & GDH.ChilltoBloom90.CU & GDH.ChilltoBloom90.CP & GDH.Jan1toBloom90 \\
\hline Butte & 1996 & Nonpareil & 7423 & 9398 & 7826 & 8707 \\
\hline Butte & 1997 & Nonpareil & 4585 & 7848 & 6709 & 5481 \\
\hline Butte & 1998 & Nonpareil & 5547 & 7528 & 7021 & 6034 \\
\hline Butte & 1999 & Nonpareil & 5601 & 7550 & 6591 & 5360 \\
\hline Butte & 2000 & Nonpareil & 7090 & 9017 & 7022 & 6905 \\
\hline Butte & 2001 & Nonpareil & 7213 & 7915 & 7055 & 5143 \\
\hline Butte & 2002 & Nonpareil & 3863 & 7741 & 6448 & 5643 \\
\hline Butte & 2003 & Nonpareil & 6211 & 7793 & 6211 & 5554 \\
\hline Butte & 2004 & Nonpareil & 5625 & 8573 & 6508 & 5490 \\
\hline Butte & 2005 & Nonpareil & 5439 & 7521 & 5800 & 4834 \\
\hline Butte & 2006 & Nonpareil & 8601 & 9177 & 6315 & 6128 \\
\hline Manteca & 1996 & Nonpareil & 6407 & 8546 & 7533 & 7657 \\
\hline Manteca & \begin{tabular}{|l|}
1997 \\
\end{tabular} & Nonpareil & 4329 & 6516 & 6654 & 5093 \\
\hline Manteca & 1998 & Nonpareil & 7283 & 8092 & 7464 & 7054 \\
\hline Manteca & 1999 & Nonpareil & 5926 & 6854 & 5938 & 5642 \\
\hline Manteca & 2000 & Nonpareil & 8278 & 9709 & 8156 & 7808 \\
\hline Manteca & 2001 & Nonpareil & 6210 & 8068 & 6969 & 5305 \\
\hline Manteca & 2002 & Nonpareil & 3778 & 7776 & 5009 & 5749 \\
\hline Manteca & 2003 & Nonpareil & 6175 & 8729 & 6855 & 5978 \\
\hline Manteca & 2004 & Nonpareil & 5485 & 9118 & 6896 & 5681 \\
\hline Manteca & 2005 & Nonpareil & 5830 & 7862 & 7001 & 5074 \\
\hline Manteca & 2006 & Nonpareil & 4756 & 8543 & 5246 & 5653 \\
\hline Kern & 1996 & Nonpareil & 6596 & 8333 & 6335 & 7296 \\
\hline Kern & 1997 & Nonpareil & 7603 & 8078 & 7119 & 6727 \\
\hline Kern & 1998 & Nonpareil & 8080 & 8488 & 8024 & 7668 \\
\hline Kern & 1999 & Nonpareil & 7268 & 8686 & 6821 & 6484 \\
\hline Kern & 2000 & Nonpareil & 9640 & 9989 & 8409 & 8548 \\
\hline
\end{tabular}




\section{Nonpareil Raw Data}

\begin{tabular}{|l|l|l|l|c|c|c|}
\hline Kern & 2001 & Nonpareil & 8446 & 8968 & 7124 & 6215 \\
\hline Kern & 2002 & Nonpareil & 7835 & 8702 & 7822 & 7062 \\
\hline Kern & 2003 & Nonpareil & 7148 & 9035 & 6684 & 6479 \\
\hline Kern & 2004 & Nonpareil & 6473 & 9175 & 6665 & 6191 \\
\hline Kern & 2005 & Nonpareil & 7986 & 9291 & 8020 & 7098 \\
\hline Kern & 2006 & Nonpareil & 7393 & 10092 & 5825 & 7393 \\
\hline
\end{tabular}




\section{Mission Raw Data}

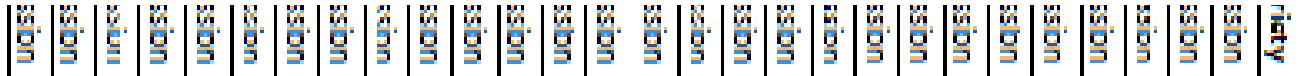

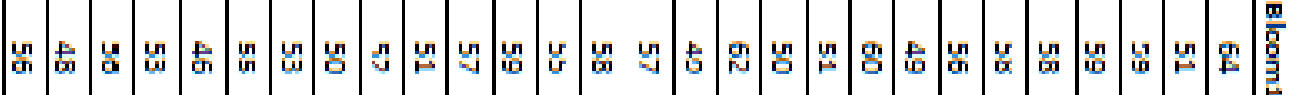
a

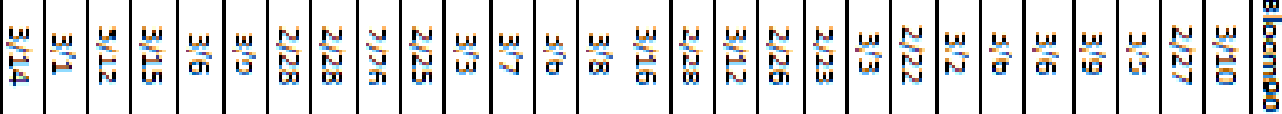

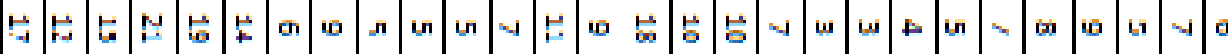
m

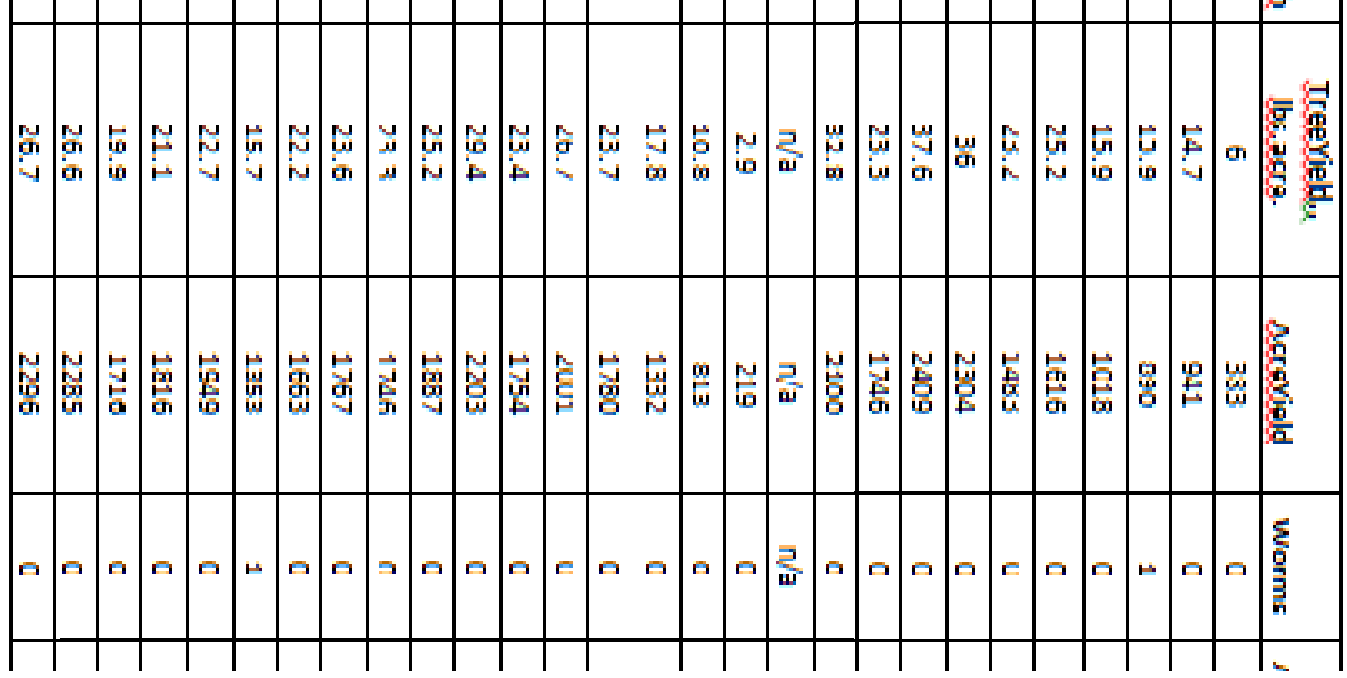




\section{N. Mission Raw Data}

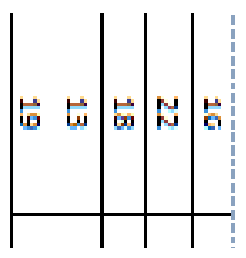

\section{O. Mission Raw Data}

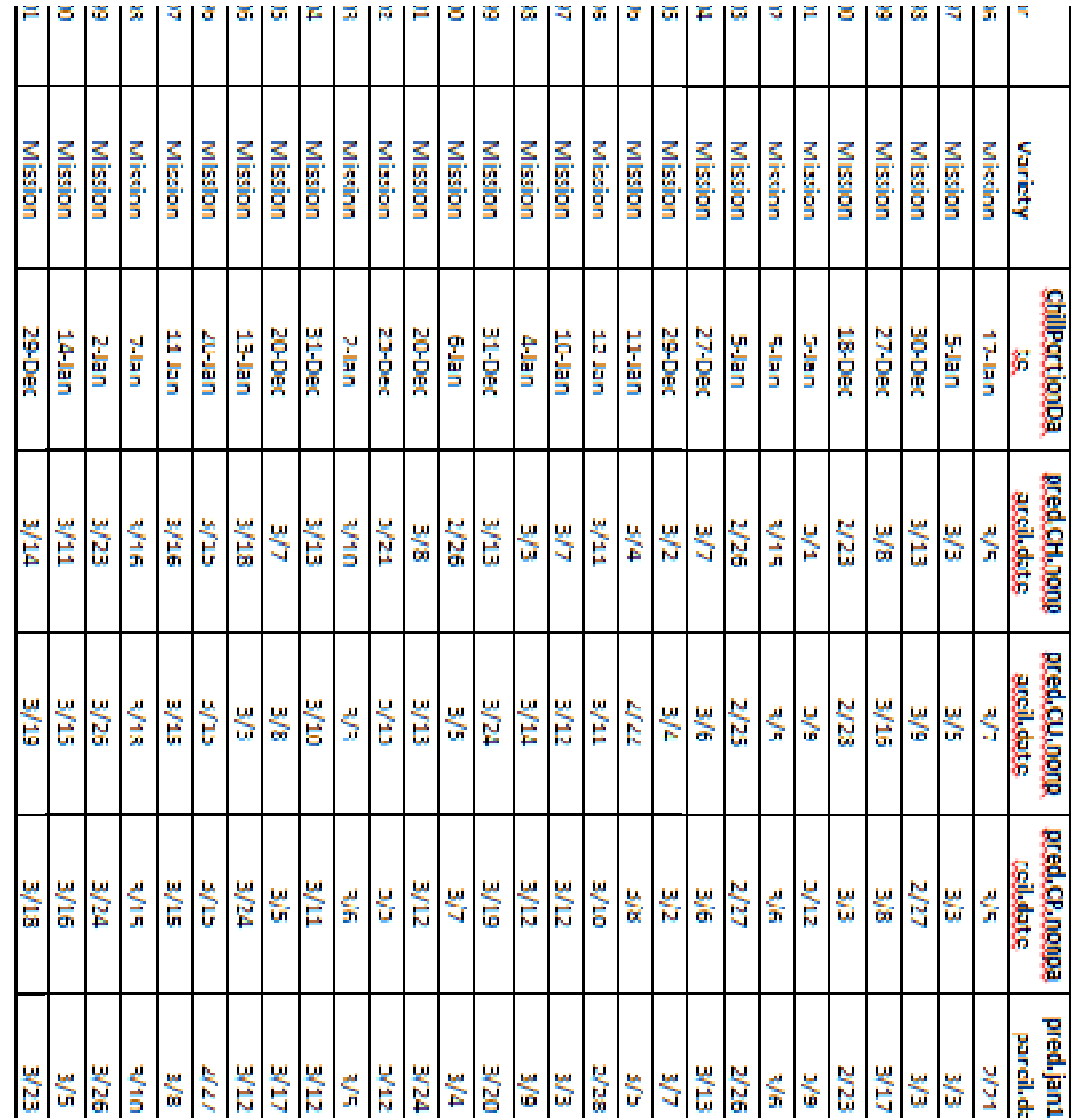


P. Mission Raw Data

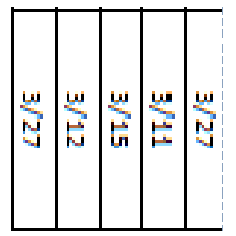




\section{Q. Mission Raw Data}

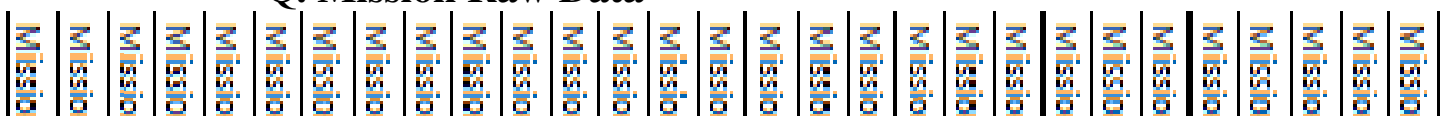

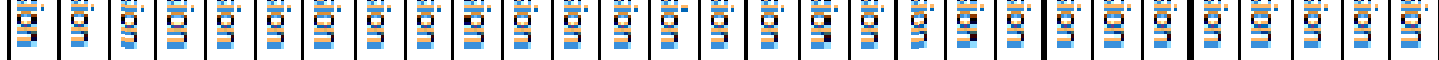

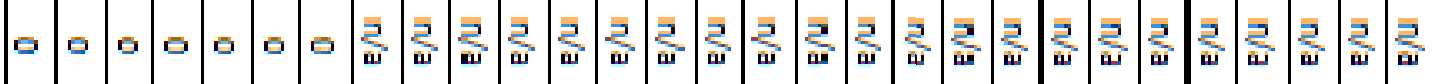

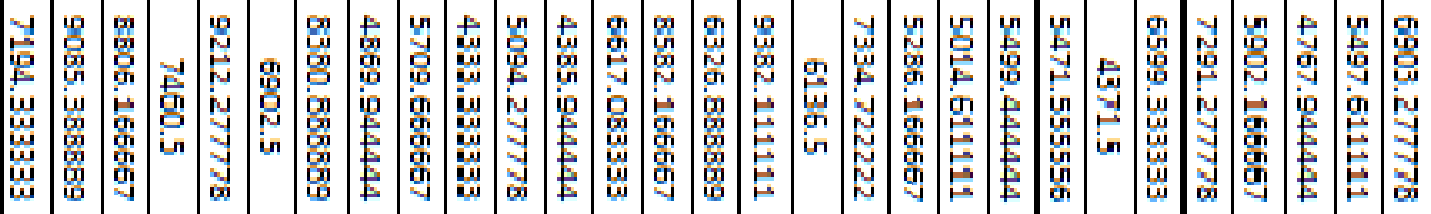

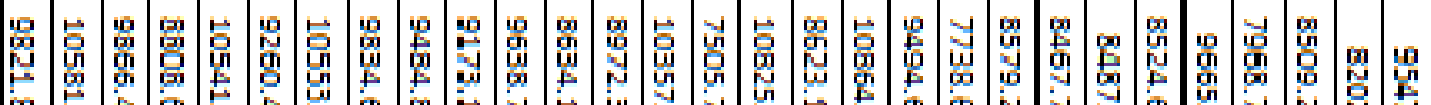

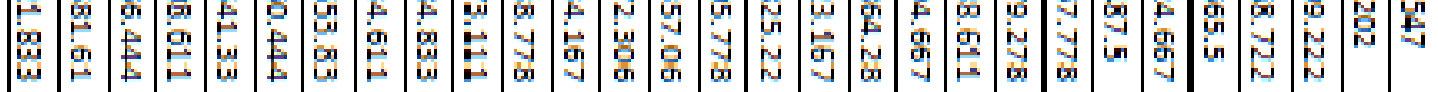

莣罵

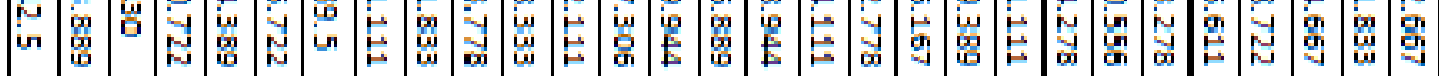

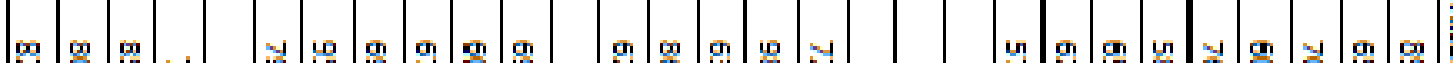




\section{R. Mission Raw Data}

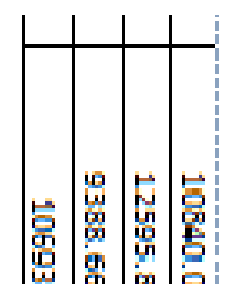

